\title{
APROPRIAÇÃO DE TEXTO: Um Jogo de Imagens
}

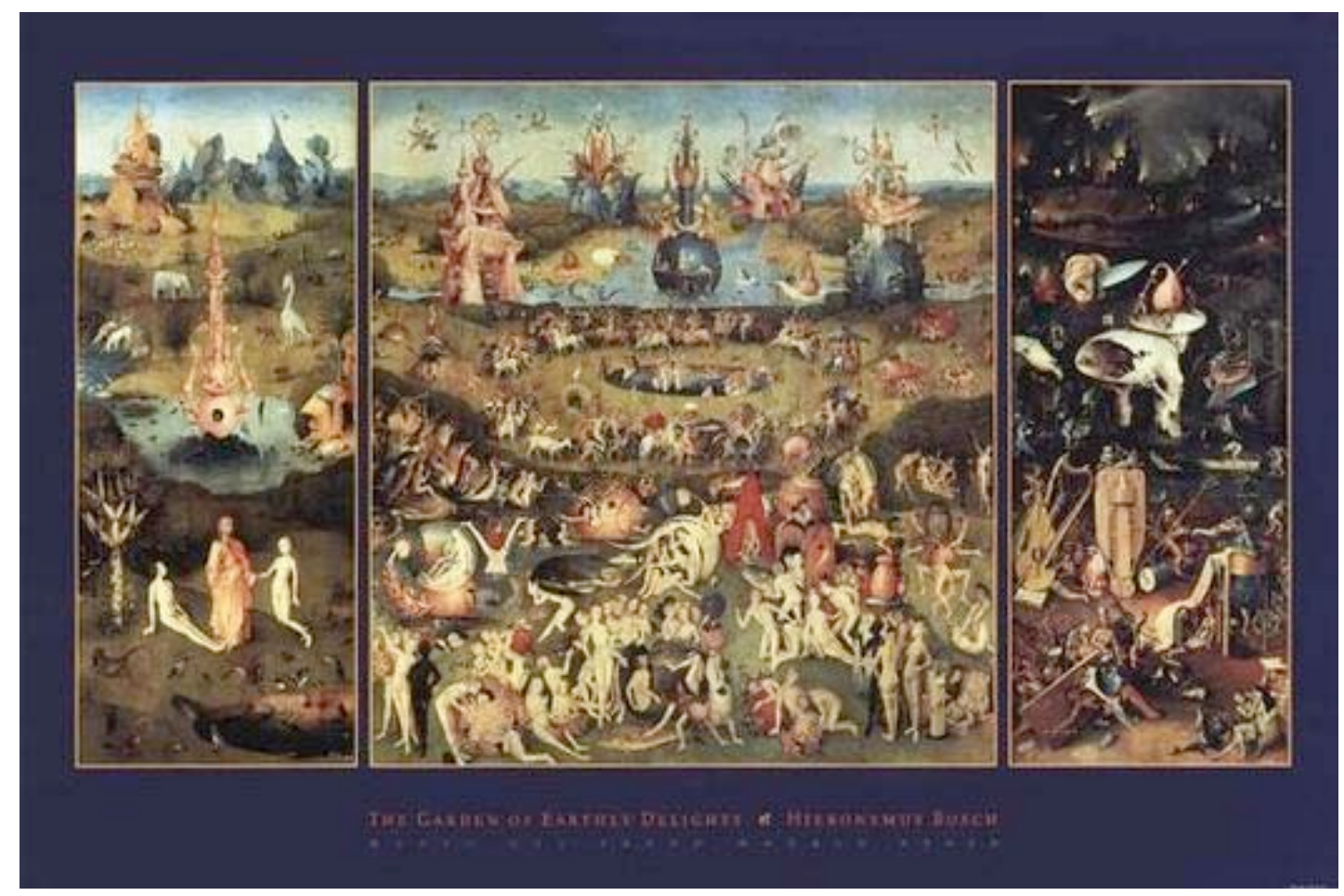

REJANE KASTING ARRUDA

Dissertação apresentada ao Programa de Pós-Graduação em Artes, Área de Concentração Pedagogia do Teatro, Linha de Pesquisa Formação do Artista Teatral, da Escola de Comunicações e Artes da Universidade de São Paulo, como exigência parcial para obtenção do Título de Mestre em Artes, sob a orientação do Prof. Dr. Armando Sergio da Silva. 
REJANE KASTING ARRUDA

\section{APROPRIAÇÃO DE TEXTO: UM JOGO DE IMAGENS}

Dissertação apresentada ao Programa de Mestrado em Artes, Área de Concentração Pedagogia do Teatro, Linha de Pesquisa Formação do Artista Teatral, da Escola de Comunicações e Artes da Universidade de São Paulo, como exigência parcial para obtenção do Título de Mestre em Artes, sob a orientação do Prof. Dr. Armando Sergio da Silva.

SÃO PAULO

2009 
Autorizo a reprodução e divulgação total ou parcial deste trabalho, por qualquer meio convencional ou eletrônico, para fins de estudo e pesquisa, desde que citada a fonte.

\author{
Catalogação da Publicação \\ Serviço de Biblioteca e Documentação
}

Escola de Comunicações e Artes da Universidade de São Paulo

Arruda, Rejane Kasting

Apropriação de Texto: Um Jogo de Imagens - São Paulo: R. K. Arruda, orientador Armando Sergio da Silva - São Paulo, 2009.

132. f.: il

Dissertação (Mestrado) - Universidade de São Paulo, 2009.

1. Apropriação de Texto 2. Jogo 3. Pedagogia do Teatro 4. Ação Física 5. Ator I. Silva, Armando Sérgio da. II. Título. 
Comissão examinadora 


\section{Agradecimentos}

Ao professor Armando Sérgio pela oportunidade de aprender, pelo seu incondicional amor ao ator.

Aos colegas do CEPECA pelo constante diálogo, pelas palavras trocadas.

Ao ator José Dornellas pelo caminho compartilhado, pela dedicação.

'A Fundação de Amparo a Pesquisa no Estado de São Paulo (FAPESP) pelo valioso apoio.

A Fausto Vianna pelas "flores de tule e fitas de veludo".

Aos funcionários do CAC pela disponibilidade, pela amizade.

A professora Maria Lucia Pupo e Marcio Aurélio pela crucial contribuição.

A Gilberto Gobatto pela conversa, divisora de águas.

Aos atores que participaram das oficinas de $O$ Devir da Linguagem Teatral Enquanto Experiência Didática, Sandra Meyer e Celso Santos pelo espaço em Florianópolis.

Aos atores da Cia Acting-Out, com os quais partilhei o início da pesquisa (Simonia Queiroz, Caca Manica, André Auke, Rico Malta, Leandro Destazio e Elize Guedes) e aos nossos queridos colaboradores Renata Araújo e Paulo Marcello.

Ao Grupo Poetas Livres e a Escola Praia do Rizo pela participação.

A meus alunos do Teatro Vocacional pelo carinho e aprendizagem.

A meus pais pelo eterno apoio.

A meu marido Augusto Pinto pela compreensão incondicional. 


\section{Resumo}

Esta pesquisa surge de um desejo de sistematizar a prática com a Memorização Através da Escrita em função do processo de criação do ator com o texto dramático. Utilizo a noção de "jogo" spoliana e proponho o "foco" como instância organizadora do traballho. Investiguei duas modalidades de jogo distintas que contam com a Memorização Através da Escrita como procedimento introdutório. A primeira implica a transformação de partituras físicas em ações físicas. A segunda implica uma sucessão de revesamentos do "foco" onde estas ações são resgatadas no "lugar do espontâneo". Uma seqüência de "palavras inventadas" divide o foco com a enunciação do textodado e com "regras" que organizam o corpo no espaço. Monta-se, assim, um esquema dinâmico de revesamentos do foco que mantém ativos os impulsos para a fala e para a inscrição das ações.

Palavras-chaves: Apropriação de Texto - Jogo - Pedagogia do Teatro - Ação Física - Ator. 


\begin{abstract}
This research came from a desire of systematize the practical work of the actor beyond memorizing the dramatic text from writing at the process of actor's creation. Actually I use the notion of "game" from Viola Spolin and I do suggest the "focus" as manner of organize the entire work. I investigated two kind of distinguished modalities of game based on the memorization from writing at the beginning of the work. The first implicates the transformation of physical scores into physical actions. The second implicates in a succession of focus setbacks where this actions are rescued replacing "the spontaneous". An invented word sequence divides the focus with the text enunciation and with some rules that organize the body on the space. In this way is possible to put on the stage a dynamic schedule of focusing that keep active the impulses to speech and for the insertion of actions.
\end{abstract}

Key-words: Text appropriation - Play -Theater's Pedagogy - Physical action - Actor. 


\section{Sumário}

Introdução 12

\section{Capítulo 1}

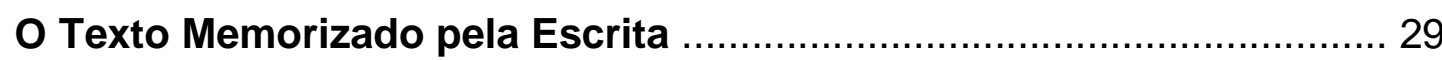

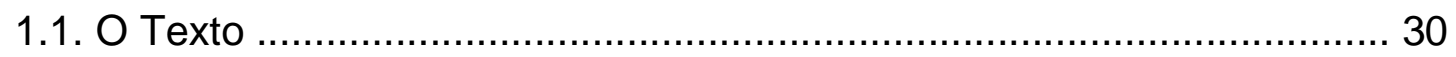

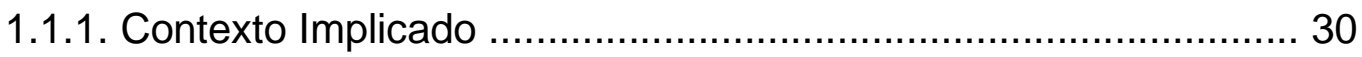

1.1.2. A Oralidade ............................................................... 33

1.1.3. Relação com a Ação ....................................................... 33

1.1.4. Engajamento, Endereçamento ...................................... 34

1.1.5. Relação com o Passado ...................................................... 34

1.1.6. Identificação dos Enunciadores .............................................. 34

1.1.7. A Divisão em Fragmentos ............................................. 35

1.2. A Memorização do Texto Através da Escrita ................................... 36

1.2.1. Despedaçamento, Encadeamento ..................................... 38

1.2.2. Tensão e Relaxamento ................................................... 43

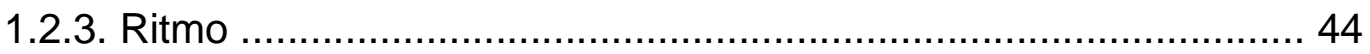

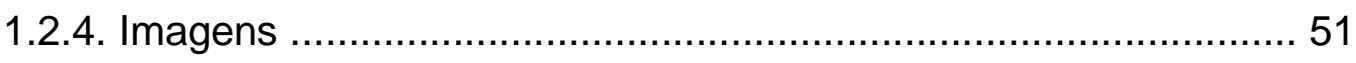

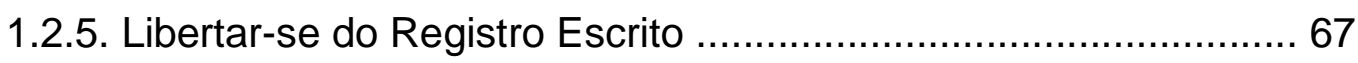

1.2.6. Pensar o Texto ............................................................. 68

\section{Capítulo 2}

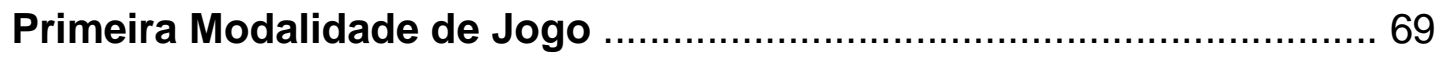

2.1. A Transformação da Partitura .............................................. 70 
2.2. A Partitura de Mimesis de Performance .............................................. 72



2.2.2. Qualidades Físicas em Foco .................................................... 74

2.2.3. A Inscrição Espontânea de Imagens ......................................... 76

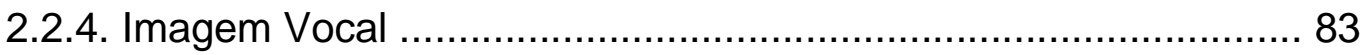

2.2.5. Absorção, Problematização ……………………………….... 85

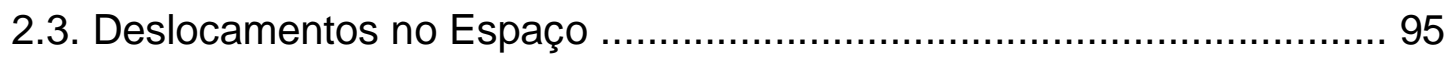

2.3.1. Percursos Desenhados na Folha de Papel ................................ 95

2.3.2. Imagens de Filmes ................................................................ 97

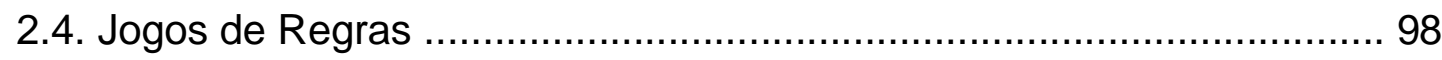

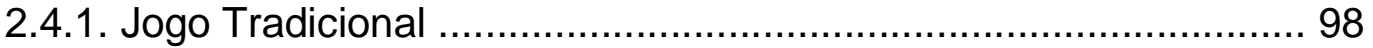

2.4.2. Jogo Teatral ...................................................................... 100

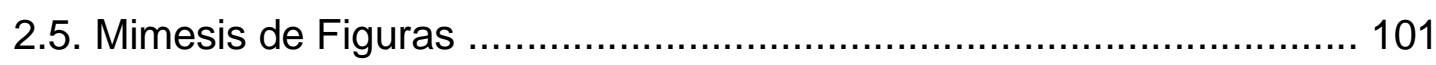

2.5.1. Figuras Masculinas ............................................................. 101



2.5.3. O Esquecimento como Auxiliar ................................................ 105

2.6. Associações Cotidianas ……........................................................... 106

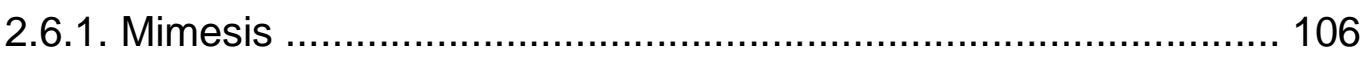

2.6.2. Imagem Acústica ............................................................... 110

\section{Capítulo 3}

Segunda Modalidade de Jogo ……………………...................... 112

3.1. Criação e Memorização das Palavras Inventadas ............................. 113

3.1.1. A Criação das Palavras ........................................................ 113

3.1.2. Memorização da Subpartitura Através da Escrita ...................... 116 
3.2. O Jogo com a Subpartitura …………………….......................... 117

3.2.1. A Estrutura de Regras ….................................................. 117

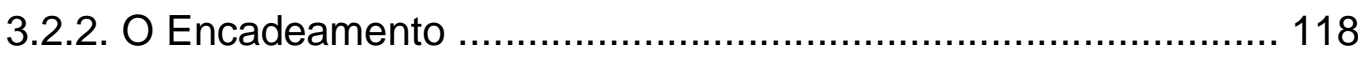

3.2.3. O Esquema de Revesamentos ............................................ 122



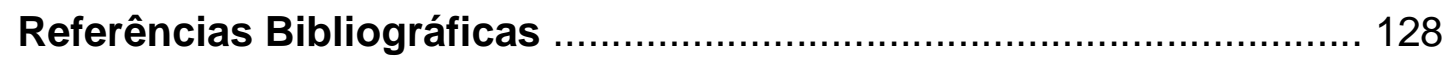


Eu me identifico com a linguagem, mas somente ao me perder nela como objeto.

Lacan 


\section{Introdução}

Aquilo que não encerra utilidade, nem verdade, nem valor simbólico, mas também não acarreta conseqüências nefastas, pode ser apreciado mediante o critério do encanto que possui e pelo prazer que provoca. Esse prazer, dado que não tem como conseqüência um bem ou um mal dignos de nota, constitui um jogo.

Platão 
Sou atriz. Atuo no campo da formação do ator e compartilho das preocupações a respeito da evidência de princípios que orientam a prática. Realizo pesquisa na Universidade de São Paulo junto ao CEPECA (Centro de Pesquisa em Experimentação Cênica do Ator). A pesquisa é estruturada com vivências compartilhadas em workshops quinzenais nos quais expomos cenas e recebemos a interlocução dos atores-pesquisadores reunidos sob a coordenação do professor Armando Sérgio. Semestralmente estes workshops são compartilhados, também, com o público, com o qual debatemos as resultantes e os caminhos percorridos. O processo vivenciado com o texto Quarteto, de Heiner Müller, é o último de uma série de tentativas para a formalização de uma prática de apropriação do texto como jogo. Menos para decantar um passo a passo. Mais para extrair princípios, fundamentar novas experiências, abrir caminhos.

Há um princípio que da prática vivenciada tomei como premissa, a condição fundamental do estar em cena: a necessidade de "expor-se ao jogo" (tomando "jogo" como "improvisação com regras"). Ao aventurar-me no processo de apropriação do texto me comprometo com o jogo. Este princípio norteou a montagem de Hamlet Machine (de Heiner Müller) com a Cia ActingOut (apresentada em setembro de 2007 no Sesc Pinheiros, em São Paulo). Apoios teóricos fortaleceram o que parecia ser um paradigma para a apropriação do texto. Estes apoios vinham de Spolin, Stanislávski, Grotóvski, Barba, Sausurre, Ubersfeld, Kusnet, Knébel, Maria Lucia Pupo, Lacan. Com as suas proposições era possível precisar um olhar sobre a prática, de maneira que a experiência subjetiva passava `a formalização. 
Viola Spolin lançou as bases do teatro improvisacional nos Estados Unidos no começo do século XX e criou modalidades diversas de jogos teatrais. O que me impressionou não foi a diversidade de modalidades criadas (também), mas o princípio que ela evidenciava: só poderia haver o "espontâneo" quando houvesse o "foco". Ela tocava, de certa maneira, em uma percepção advinda da prática: existe uma "estrutura" de jogo. Uma estrutura que independe das "modalidades" de jogo. Uma estrutura de três posições: foco, espontâneo (ou instantâneo) e resultante. Elementos se revesavam "no lugar do foco", "no lugar do que acontece instantaneamente" (sem preparar, sem intencionalidade); e havia o "lugar reservado `a resultante". A escolha de elementos para estas três posições determinava "modalidades" diferentes de jogo.

Spolin dava dicas sobre o funcionamento desta estrutura. O "Foco" (utilizado por ela com letra maiúscula) era o agente. Sem ele não haveria o jogo. Honestamente dedicado ao foco 0 ator cria soluções: "A energia liberada para resolver o problema, sendo restringida pelas regras do jogo (...) cria uma explosão - ou espontaneidade" (idem: 5). O elemento que "resolve" o jogo é inscrito como "espontâneo". Dedicando-se ao foco seria possível construir resultantes, ou seja, elementos, ações, não enquadradas a anteriori na leitura de um texto dramático, não pensadas, não planejadas: "Essa singularidade de foco num ponto (...) libera o aluno para a ação espontânea e é veículo para uma experiência orgânica" (SPOLIN, 1992: 21). O foco seria o pivô. Poderiam situá-lo: regras, imagens, problemas a resolver (problemas técnicos, que muitas vezes "provocam jogo"), etc. 
Havia, também, o apoio de Grotóvski, pois a ação física era vista como: "o impulso claro, o impulso puro. As ações dos atores são, para nós, símbolos. (...) Não posso definí-lo mas sei o que é" (GROTOWSKI, 1987: 193 apud FERRACINI, 2001: 90). No entanto, "questões" fragilizavam a prática. O paradigma para a apropriação do texto não implicava, apenas, a "criação" do impulso, mas a sua permanência: a "repetição". Era necessário construir modalidades de jogo que implicassem uma estabilidade da partitura cênica e possibilitasse a repetição dos mesmos impulsos. Além disso, a apropriação do texto não implicava, somente, a ação física como "impulso", mas, também, como "ficção". Era preciso "contornar" a ficção, desenhá-la, para que o público pudesse jogar com uma composição imaginária. Era necessário articular o contexto de realização da obra (o "jogo do ator") com o contexto a ser "imaginado" (evocado, criado, construído): o "ficcional", que contava com a "idéia de personagem", de "alguém que age".

Com o clássico "exemplo do cachimbo", Grotóvski mostrava que a ação física implicava não apenas o "impulso" mas a "relação com o outro", a espectativa, a idéia de utilidade "para alguém". A idéia de ação articulava-se ‘a noção de "alguém que age". A atividade cênica, plástica, do corpo situado no espaço-tempo, ganhava estatuto de ação quando veiculava esta idéia.

As atividades não são ações físicas. As atividades no sentido de limpar o chão, lavar os pratos, fumar cachimbo, não são ações físicas, são atividades. (...) Mas a atividade pode se transformar em ação física. Por exemplo, se vocês me colocarem uma pergunta muito embaraçosa, que é quase sempre a regra, eu tenho que ganhar tempo. Começo então a preparar meu cachimbo de maneira muito "sólida". Neste momento vira ação física, porque isto me serve neste momento. Estou realmente muito ocupado em preparar o cachimbo, acender o fogo, assim depois posso responder `a pergunta (1).

1. GROTOWSKI, Jergy. Conferência a Santo Arcângelo, em julho de 1988. Transcrição e tradução de Dinah Kleve. Não publicada. 
A proposição de Grotóvski implicava a articulação de elementos, um encadeamento, uma pequena narrativa: "vocês me fazem a pergunta, eu acendo o cachimbo e depois respondo" (*). Havia o "embaraço" (a "pergunta era embaraçosa" e ele acendia o cachimbo): uma "imagem" permeava a transformação da atividade em ação. Esta proposição apontava para dois princípios: "não adiantava inscrever apenas o impulso da fala se esta não se integrasse ao corpo de maneira a evocar outras imagens" e, por outro lado, "a seqüência de ações físicas inscritas em cena implicava a necessidade de concatenação através da produção/associação de outras imagens".

Esses princípios tocavam em uma relação muito íntima entre a imagem "do corpo" e a imagem acústica (texto), dois elementos "diferentes" que podiam evocar juntos outras imagens. Corpo e palavra estavam na mesma ordem: a ordem dos elementos que se inscrevem em cena como impulso. Ao estabelecerem relação, os dois elementos "evocam" ação. De maneira que, na prática, a "palavra" entrava no "contexto do ator" (o que Kusnet chama de "primeira instalação"). O "contexto ficcional" era "evocado" ("segunda instalação"). Teoricamente, eu precisava da noção de "palavra" enquanto um "elemento" a ser introduzido em cena para evocar, a posteriori (através de uma relação assumida com o corpo), a ação. Da mesma maneira que a ação física, a palavra não poderia "ser definida": ela não era "todos os outros", era "diferença", um "significante". O apoio estava em Sausurre.

Sausurre lançou, no começo do século XX, as bases da

(*) Estamos tratando da estrutura narrativa como uma construção imagética (construção que conta com o trabalho de recepção e concatenação dos elementos): "A organização da narrativa se faz pois no nível da interpretação e não no dos acontecimentos-a-interpretar (...) simplesmente, essa organização se situa no nível das idéias, não no dos acontecimentos" (TODOROV, As Estruturas Narrativas. São Paulo: Perspectiva, 2003, pg. 117). 
Lingüística Moderna e do Estruturalismo $\left({ }^{*}\right)$. Formulou um conceito de signo em oposição `a noção de símbolo como a "relação fixa" entre um significante (imagem acústica) e um significado: por exemplo, "o símbolo da justiça é a balança", noção também contrária a Grotóvski quando utiliza o termo, pois a ação física "não pode ser definida". Em Sausurre, o significante (imagem acústica, impressão acústica ou impressão psíquica) $\left(^{(*}\right)$ compõe um jogo de relações, articulações, oposições, combinações (o "jogo da linguagem").

A linguagem se constitui como um sistema baseado na oposição psíquica dessas impressões acústicas, do mesmo modo que um tapete é uma obra de arte produzida pela oposição visual de fios de cores diferentes; o que importa é o jogo dessas oposições. (1)

As proposições de Sausurre foram utilizadas no campo das ciências humanas, no estudo das artes e da semiótica, de maneira que signo passou a ser não apenas o "verbal" mas "imagens". Era possível, então, tomar a "imagem do corpo" como signo, a parte do signo inscrita em cena, ou seja, o significante. De maneira que tomei, tanto para a "impressão visual" (a imagem do corpo) quanto para a "impressão acústica" (a imagem da palavra), a noção de significante. A ser inscrito como impulso, para, com outros, "evocar" ação.

Segundo Sausurre, um significante jamais está só. É preciso pelo menos dois para extrair uma significação. De maneira que o "efeito de

(*) O Estruturalismo se preocupou em extrair princípios de um campo de investigação próprio. Se instalou em diversas áreas do conhecimento. Encontrando seu ápce na década de sessenta, cedeu lugar ao Pós-estruturalismo. São estruturalistas Lévi-Strauss na Antropologia, Foucault na História, Barthes na Literatura, Greimas na Semântica, Lacan na Psicanálise, Jakobson na Lingüística (só para citar alguns). Ver mais em DOSSO, François. História do Estruturalismo, Volume I. Bauru, SP: Edusc, 2007 e em SAUSURRE, Ferdinad. Curso de Lingüística Geral. São Paulo: Cultrix, 2006.

$\left({ }^{* *}\right)$ Os quatro termos são utilizados por Ferdinand Sausurre.

1. SAUSURRE, Ferdinand. Curso de Lingüística Geral. São Paulo: Cultrix, 2006, pg. 43. 
significação" depende das "relações" entre os elementos encadeados e, também, de "associações" realizadas com "elementos ausentes". Este tópico é importante. O encadeamento não fala "por sï. Há um "outro eixo", que não é o eixo da inscrição cênica, mas um eixo vertical de "possíveis" (de "associações"). Sausurre o chama propriamente de eixo vertical em oposição ao eixo horizontal do encadeamento dos elementos.

É da relação entre o encadeamento e o eixo vertical (que se dá por "associação") que a significação é extraída. Esta é uma característica da linguagem, um princípio utilizado, também, em outras áreas. Greimas o utilizou na Semântica e Anne Ubersfeld o adotou na Semiótica do Teatro (*). Cada termo posto no encadeamento traz algo novo e provoca associações. Tomei a imagem acústica como o "segundo termo" do encadeamento, a entrar em relação com a imagem do corpo já inscrita em cena. Primeiro "aparece" a ação física para "depois" nascer a palavra. Como na ordem apresentada por Grotóvski: ganho tempo e "depois" respondo a pergunta. A ação é "evocada" da "relação" entre os significantes encadeados e, também, da associação com outros significantes, "evocados", "implicados".

\section{Procedimentos}

Não era raro encontrarmos atores que informalmente utilizavam a "escrita" para a memorização do texto. Memorizado com a repetição do seu registro escrito, sem imagem vocal, descomprometido com a significação, o

(*) A estrutura actancial de Ubersfeld fundamenta a sua proposta de análise do texto. Ela lança mão do conceito de actante proposto por Greimas e das estruturas narrativas de Propp e Saurriau. Trabalha com a noção de cruzamento entre o eixo horizontal e o eixo vertical. Ver em UBERSFELD, Anne. Para Ler o Teatro. São Paulo: Perspectiva, 2005. 
texto era introduzido em cena sem vínculos. Em jogo, ao combinar-se com o corpo, os vínculos eram construídos. Em 1997 me deparei com uma espécie de sistematização deste procedimento. Utilizado por atores da Fondazione Pontedera Teatro $\left({ }^{*}\right)$ na criação de seus espetáculos, a Memorização Através da Escrita vinha sendo difundida por Cacá Carvalho, François Khan e Humberto Brevilheri (em trabalhos com grupos de teatro, cursos em universidades e festivais, workshops, oficinas). Uma formalização chegou até mim via François Khan.

\begin{tabular}{|l|}
\hline \multicolumn{1}{|c|}{ MEMORIZAÇÃO ATRAVÉS DA ESCRITA } \\
- Frase por frase. \\
- Olhar no original, corrigir e re-escrever corretamente. \\
2) Pensar o texto: \\
- Ler o texto e pensar o texto com os olhos fechados. \\
- Pensar o texto com os olhos abertos fazendo uma ação concreta. \\
Obs: Não fixar a interpretação quando ler o texto.
\end{tabular}

Há dez anos, em formação na Universidade de São Paulo, tive acesso a sistemáticas específicas para uma pedagogia do teatro e para uma pedagogia do ator. Não as via como dicotômicas. Ao contrário, percebia uma possibilidade de intersecção. Uma intersecção que implica a seleção, o recorte, em função de um objeto específico de investigação: a prática com a Memorização Através da Escrita para o processo de apropriação do texto como jogo. Não procurei dar conta, portanto, dos sistemas implicados, não 
me ative `as problemáticas de sua difusão e historicidade. Propús, apenas, buscar, em minha própria vivência, o que poderia ser validado para a criação da fala como jogo e da sua inscrição como impulso e elemento que evoca (junto ao corpo) a ação.

O Treinamento Físico para o Ator era uma prática minuciosa, sistematizada, e foi de grande importância em minha formação. A questão de como introduzir o corpo em cena era absolutamente problemática. O contato com a imensidão do espaço, com o enigma da presença do outro, com o seu olhar, tudo isto intimidava. O corpo se retraia, contorcia, trazia repertórios "batizados". Este era um lugar absolutamente experimentado pelos que estavam em cena. Bastava estarmos diante do "olhar que nos recorta", "invade", para a unidade do corpo se perder. Até que algo fosse construído a cena era o lugar do vazio $\left(^{\star}\right)$, de maneira que o que era construído "voltava".

Viola Spolin sistematiza um exercício belíssimo, o primeiro de seu "fichário", chamado Exposição $\left.{ }^{(*}\right)$. O experimentei, também, com alunos. $O$ corpo sucumbe `a timidez, ao medo, ao susto, ao vazio, até que algo seja construído: uma imagem, um pensamento, um foco. Quando Spolin oferece o foco - "contar cadeiras", por exemplo (simplesmente contar as cadeiras do espaço) - o corpo se organiza. É preciso um foco. Diante do olhar externo a organicidade "pula". Não é preciso tanto para estar orgânico, portanto, basta o olhar do outro. No entanto, não sabemos o que fazer com o "excesso".

(*) Encenadores-pedagogos muitas vezes lançam mão da noção de "vazio". No Brasil temos o exemplo de Antunes Filho (participei das suas pesquisas nos anos de 1993 e 1994), que lança mão da filosofia taoísta. A idéia de que algo da ordem do pulsional precisa ser organizado em função do foco e elaborado em termos de ação física pode ser utilizada com certa tranqüilidade pois é algo profundamente vivenciado na prática.

$\left.{ }^{* *}\right)$ SPOLIN, Viola. Jogos Teatrais: O Fichário de Viola Spolin. São Paulo: Perspectiva, 2000, jogo A1. Permanecer durante um bom tempo sozinho em cena olhando para as pessoas na platéia sem um foco definido. 
Voltando ao Treinamento Físico para o Ator, o que se propõe é uma sistematização do "como colocar o corpo em cena", como organizá-lo e potencializar sua "presença" em função da construção da ação física. Há variantes do Treinamento Físico; há uma tradição, uma "cultura do treinamento" que se vale da investigação continuada de encenadorespedagogos. Eugênio Barba se propôs a extrair princípios que regem a "posta do corpo em cena" e fundou a Antropologia Teatral, lançando mão da noção de "ator-dançarino": estar em um corpo é dançar. A modalidade que chegou até mim foi sistematizada pelos atores do Odin Teatret e implica a construção de partituras físicas (*). Para construí-las são necessários objetos (bastão), mimesis de imagens pictóricas ou atividades ("lançar", "empurrar", "puxar", "andar", "sentar") (**).

Nas práticas desenvolvidas por Jan Ferslev e Elisabeth Lopes $\left(^{(* *}\right)$ criávamos partituras físicas e, em função da integração com o contexto elaborado para a performance, alterávamos o seu contorno. As partituras eram propriamente "desconstruídas" quando integradas a elementos como: "prostituta na praça", "professorinha suburbana se prostitui para sustentar as irmãs" (Otto Lara Resende ou Bonitinha Mais Ordinária, de Nelson Rodrigues) $\left.{ }^{\star * \star *}\right)$, "mulher de pescador espera o barco chegar", etc.

Se analisarmos esta "desconstrução" (ou "transformação") como

$\left(^{*}\right)$ "Falar em partitura significa falar de materiais que podem ser elaborados, fixados, combinados e reproduzidos" (BONFITTO, 2007: 80).

$\left.{ }^{(* *}\right)$ O termo utilizado no treinamento é "ação". Estou lançando mão da diferenciação proposta: atividades de lançar, puxar, empurrar podem "ser transformadas" em ação física.

$\left.{ }^{* * *}\right)$ Jan Ferslev é ator do Odin e Elisabeth Lopes é encenadora expoente e professora da Universidade de São Paulo. Estudou na École de Mimodrame, fundada por Etiene Decroux, e acompanhou o trabalho de seguidores como Corine Saum, Steve Wasson e Thomas Leabjart. Estudou, também, com Iben Nagel Rasmussen, do Odin Teatret.

${ }^{(* * *)}$ Espetáculo encenado por Elisabeth Lopes no Teatro Laboratório da Universidade de São Paulo em 1998. 
jogo, há um foco ("mulher de pescador espera o barco chegar") e a resultante (ações físicas originadas da "transformação" da partitura). Entre foco e resultante, algo "acontece", pois a partitura é totalmente modificada. Muitas vezes contávamos com um texto que, ao assumir relação com a ação física inscrita no momento do jogo, "evocava" algo que não havia sido "enquadrado" no ato de leitura e interpretação a anteriori decantado.

Já a prática desenvolvida por Maria Lucia Pupo estava voltada para uma pedagogia do teatro. Independente do engajamento ou não na profissão de ator, o que estava em questão era a atividade lúdica $\left({ }^{*}\right)$. Utilizávamos fragmentos de texto: recorte de jornal, conto, crônica, drama. Haviam elementos (regras, variações do estatuto e função do narrador, encadeamento fixo de imagens, etc) que estruturavam a "posta em cena" e organizavam o corpo-tempo-espaço para que a fala fosse inscrita ips literis. Era enfatizado o caráter aleatório dos elementos que diziam respeito a questões da linguagem e não ao imaginário em torno da fábula ou o sentido da ação. O efeito de significação contava, então, com a integração dos elementos e certa dose de acaso, improvisação: "Por meio dessa simbiose entre o acaso e a escolha deliberada é preparado o terreno para fazer emergir a noção contida no enunciado (...) (PUPO, 2005: 104).

\footnotetext{
Uma vez desmontada a noção do texto como receptáculo de um significado a ser extraído, o que aparece é a imagem de um feixe de possibilidades a serem atualizadas através da performance. Salta assim, para o primeiro plano, a importância das condições de enunciação desse mesmo texto. (1)
}

(*) O termo lúdico vem do latim ludus: "Contrastando fortemente com a heterogeneidade e a instabilidade das designações da função lúdica em grego, o latim cobre todo o terreno do jogo com uma única palavra: ludus, de ludere" (HUIZINGA, Johan. Homo Ludens. São Paulo: Perspectiva, 2008, pg. 41).

1. PUPO, Maria Lúcia. Entre o Mediterrâneo e o Atlântico: Uma Aventura Teatral. São Paulo: Perspectiva, 2005, pg. 49. 
O texto pode ser jogado de diferentes maneiras; cada um pode descobrir coisas que outros não perceberam, o que evidencia o aspecto plural que pode ter a leitura de um texto; seu sentido não é único, nem é dado de antemão. (1)

O desafio consiste em formular modalidades lúdicas que possam aliar a associação temática entre o texto e o desejo de jogo dos participantes, por um lado, a questões próprias `a linguagem teatral, por outro. Para que a associação entre todos esses elementos se fizesse presente optamos por limitar o campo das possibilidades mediante a combinação aleatória (...). (2)

A utilização do elemento "aleatório" não implicava, apenas (e paradoxalmente) a produção da significação em jogo, mas o engajamento dos jogadores: "O jogador se aplica, se depara com tudo o que é aleatório dentro do jogo e, ao mesmo tempo, desenvolve sua capacidade de escuta, ou seja, a mobilização de todos os seus sentidos (...)" (PUPO, 2005: 54). Lançando mão desta evidência, propús a intersecção entre a partiturização física e o princípio do jogo (sem pretender dar conta da totalidade do pensamento implicado nas sistemáticas): em jogos de enunciação com fragmentos de Quarteto, partituras físicas (aleatórias) se "transformavam". Da relação entre a nova forma (ação física) e a imagem acústica (texto inscrito em cena) era possível extrair uma significação.

\section{A Pesquisa com Quarteto}

Contando com a participação do ator José Dornellas e encontros semanais com o CEPECA, me aventurei em uma sucessão de jogos de enunciação com fragmentos de Quarteto. Nos dedicamos, primeiramente, a esta modalidade, que chamamos "primeira": o texto memorizado pela

1. PUPO, Maria Lúcia, op. cit., pg. 49. A autora traz depoimentos dos participantes das oficinas coordenadas por ela em pesquisa de livre-docência.

2. PUPO, Maria Lúcia, op. cit., pg. 104. 
escrita se inscrevia como impulso na medida em que resolvia o problema de "como disfarçar a aleatoriedade da partitura física". A fala "borrava" a partitura e uma "troca" era operada: a partitura pela ação física. A imagem acústica assumia certa relação com a forma que ajudava a construir e evocava ação. No entanto, não era possível "repetir" o mesmo impulso (produzido naquele momento, naquela "partida de jogo", que criara a ação física). Percebemos a necessidade de estruturar uma "segunda modalidade de jogo", onde um constante revesamento de certos elementos na posição do foco poderia manter a "estabilidade pulsional" das resultantes.

A instância "foco" pode ser percebida nas modalidades mais simples de jogo teatral (o foco em um objeto, na comunicação com a platéia, um problema técnico, por exemplo) e nas modalidades complexas, onde este se encontra dividido (entre duas falas desenvolvidas simultaneamente, por exemplo) $\left(^{*}\right)$. Segundo Spolin, é propriamente quando o foco se encontra "dividido" que o espontâneo "acontece".

Importante no jogo é a "bola" - o Foco, um problema técnico, `as vezes um duplo problema técnico que mantém a mente (um mecanismo de censura) tão ocupada (...) que o gênio (espontaneidade), sem proteção, "acontece" (1).

Observando a prática com jogos teatrais era possível perceber que um elemento, no instante em que instalava o foco, inscrevia impulso. O que configurava o impulso, portanto, era a nova inscrição de um elemento em foco. Era possível perceber com clareza este princípio em modalidades

(*) SPOLIN, Viola. Jogos Teatrais: O Fichário de Viola Spolin. São Paulo: Perspectiva, 2000, jogo A 91.

1. SPOLIN, Viola. O jogo Teatral no Livro do Diretor. São Paulo: Perspectiva, 1999, pg. 22. 
de jogos teatrais (spolianos) onde a instrução era utilizada: "A instrução é uma das facetas geradoras (energizadoras) do processo de jogos teatrais. (...) A instrução atinge o organismo total" (SPOLIN, 1999: 25). A palavra do instrutor situava o "novo foco" e o corpo subitamente se disponibilizava, inscrevendo impulso. O mesmo acontecia com a palavra do diretor em meio `a cena: cada sentença introduzida (devidamente objetiva) no espaço-tempo conduzia o corpo, inscrevendo impulso. Neste momento de disponibilidade, algo se inscrevia no "lugar do espontâneo" (ou "instantâneo"). Também nos jogos de transformação das partituras físicas era possível perceber este princípio. No momento em que a fala transformava o corpo, a ação física (um novo elemento) era inscrita como impulso. No entanto, o impulso inscrito no momento da criação se perdia. A tendência era continuar transformando a partitura para inscrever novos impulsos.

A partir da necessidade de "partiturizar os impulsos", criamos uma segunda modalidade de jogo: imagens acústicas não enunciadas mantém-se como âncora, um elemento que "puxa", que "segura" o foco. Estas imagens acústicas nós criamos. São frases ou palavras (imperativas, objetivas) que introduzem o jogo tal como a instrução spoliana: "Para dar instruções, utilize um comando simples e direto" (idem: 25). São imagens "internas" (não são enunciadas, uma espécie de "fala interna"). Apenas permitem que o textodado, ao ser introduzido em cena, "apareça" como o "novo elemento". Substituindo a palavra interna, ele "rouba" o foco e inscreve o impulso. Esta modalidade de jogo implica sucessivas, constantes e ritmadas "trocas" de "elementos em foco". Ela implica, entre o elemento interno e o externo, a relação de "substituição" (e não de complementareidade ou expressão). 
Nossas "sentenças inventadas" foram intercaladas `as sentenças do texto-dado e memorizadas com a Memorização Através da Escrita. A repetição do registro escrito dos dois elementos juntos produz imagens acústicas como IDJIOTAVAUMOUM (*). IDJIOTAVAUMOUM entrelaça (une, sustenta, enlaça) a palavra inventada "Idiota" (que situa internamente o foco) e "Valmont" (palavra a ser enunciada). "Amarrado" ao último fonema de "Idiota" está o primeiro fonema de "Valmont": IDJIO (TAVAU) MOUM. Ao situarmos o foco em IDJIOTA a enunciação de VAUMOUM torna-se inevitável.

É com IDDDJIIIÓÓÓÓÓTAAAAAAAA que me envolvo, de maneira que a ação física (construída na primeira modalidade de jogo, repertório constituído) "reaparece". Cada retorno do foco da "sentença enunciada" para a "sentença interna" renova o impulso para a inscrição de ações físicas. As ações físicas "reaparecem" (também) porque o foco se situa dividido com outros dois elementos (regras que organizam o corpo no espaço): "fazer gestos grandes" e "ocupar todo o espaço". As ações físicas se instalam porque ajudam a resolver o problema do jogo. Como "fazer gestos grandes", como "ocupar todo o espaço"? Com ações físicas. A constante ocilação entre as duas regras produz constantes e ritmados impulsos para a inscrição de ações físicas. Construímos, assim, um "esquema dinâmico de revesamentos do foco" que mantém a produção pulsional estável, fixa.

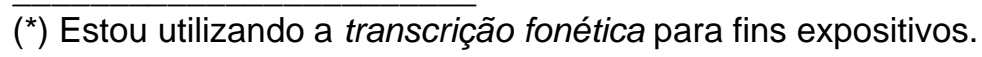




\section{O Corpo do Trabalho}

As vivências nas modalidades de jogo que criamos, bem como na Memorização Através da Escrita, estão explicitadas no corpo deste trabalho. O primeiro capítulo traz a análise das características da fala de Quarteto e a descrição de uma aplicação da Memorização Através da Escrita com o Primeiro Monólogo de Merteuil (primeiro trecho do texto). O segundo capítulo traz jogos de enunciação com partituras físicas (selecionei exemplos que considero representativos). A segunda modalidade é descrita no terceiro capítulo: a criação das palavras e as resultantes do jogo. O fato de haver a subpartitura ( ${ }^{*}$ ) "abre o espaço" para os "elementos externos" situarem as duas outras posições: o "instantâneo" ("espontâneo") e a "resultante". O corpo admite a inscrição instantânea e torna-se o palco de elementos relativamente autônomos que se recombinam, resituam, condensam, integram: um jogo de imagens.

(*) O termo é utilizado por Barba como "o forro do pensamento que o ator controla": um elemento interno fixo, partiturizado (BARBA, 1993: 176 upud BONFITTO, 2007: 82). Nossas "palavra inventadas" se configuram como uma modalidade específica de subpartitura. 
1.) Aplicação da Memorização Através da Escrita: construção do encadeamento de imagens acústicas, atividade interna e repertório de associações.

1.1. Preparação: copiar o fragmento de texto escolhido.

1.2. Tentativas de escrita memorizada: escrever o texto de memória substituindo o que não lembrar pelas próprias palavras.

1.3. Correção: comparar com o original e corrijir, completar, riscar, trocar.

1.4. Desestruturação da Escrita:

- Repetir a escrita cada vez mais rápido.

- Acelerar a escrita, tirando os olhos do papel.

- "Borrar" a caligrafia, deixando o texto "ilegível" (medida da memorização).

2.) Primeira Modalidade de Jogo: construção de ação física e imagem vocal.

- Construção de partituras físicas com: mimesis de performance, imagens de filmes, imagens pictóricas, jogos tradicionais, teatrais, de acaso, percursos no espaço.

- Transformação das partituras físicas com o auxílio de qualidades físicas e enunciação (o repertório de associações aparece no lugar do espontâneo).

- Utilização de elementos externos em jogo para construir imagem vocal.

3.) Repetição da "desestruturação da escrita": construção de imagens em torno da ficção.

- Associações com imagens já inscritas em cena (imagens do corpo em atividade).

- Associações com o universo do autor.

- Associações com "elementos externos": leituras, diálogos com o CEPECA, etc.

4.) Segunda Modalidade de Jogo: "esquema dinâmico de revesamento do foco" com uma subpartitura de "palavras inventadas" e duas regras.

- Pensar o texto na imobilidade (as imagens acústicas do texto presentes).

- Experimentar novas palavras que possam manter a mesma atividade interna.

- Fixá-las em uma ordem fixa, intercaladas `as sentenças do texto.

- Memorizar este encadeamento pela "escrita".

- Em cena, as "palavras inventadas" situam o foco, dividindo-o com duas regras: "fazer gestos grandes" e "ocupar todo o espaço".

- O repertório já construído é resgatado em função do revesamento do foco: as ações físicas são inscritas como impulso e resultam encadeadas.

- A fala é inscrita como impulso em um encadeamento de ações físicas. 


\section{Capítulo 1}

\section{O Texto Memorizado pela Escrita}

Muito importante também é o fato de que o ator, nessa forma de concentração, não deixa de agir fisicamente: ele escreve. Daí a organicidade desse processo no trabalho do ator.

Kusnet

Mesmo assim como o jogo de xadrez está todo inteiro na combinação das diferentes peças, assim também a língua tem o caráter de um sistema baseado completamente na oposição de suas unidades concretas.

Sausurre

Se dan entonces complicadas e inesperadas associaciones

Knébel

Decía que la imaginación incluye el movimiento y portanto el tiempo-ritmo. 


\subsection{O Texto}

A improvisação me interessa como o lugar do encontro de um objeto estrangeiro, exterior ao jogador, com o imaginário deste. Jean-Pierre Ryngaert

Introduzo a análise de Quarteto desenvolvida, após os jogos de enunciação e escrita, a partir de proposta sistematizada por Jean-Pierre Ryngaert (*): se a fala é abundante, se há muito ou pouco "implícito", o tipo de oralidade, indícios do estatuto dos enunciadores, se há endereçamento, engajamento, relação com a ação e com o eixo do tempo.

\subsubsection{Contexto Implicado}

A fala em Quarteto é abundante. Há um contexto, situado a partir do romance de Charlot de Laclos As Ligações Perigosas. Um suposto editor do romance organizou cartas trocadas entre personagens da época (século XVIII). No entanto, ele não sabe se as personagens realmente existiram, se a estória aconteceu, se as cartas são reais ou inventadas. Como epígrafe, uma frase de Rousseau (do prefácio de A Nova Heloísa): "Observei os costumes de meu tempo e tornei públicas estas cartas". Há um contexto socio-cultural implicado: a nobreza francesa do período anterior `a Revolução Francesa.

Junto ao salão nobre, Müller situa outro cenário: um bunker "pós Terceira Guerra Mundial". Durante o texto, não há indicação de um ou de outro e se conclui que estão "ao mesmo tempo". A fala carrega informações

(*) Professor da Universidade de Paris III e diretor teatral, Jean-Pierre Ryngaert é autor dos livros Introdução 'a Análise do Teatro; Ler o Teatro Contemporâneo; Jogar, Representar (entre outros). Ministrou diciplina na Universidade de São Paulo em 2009. Estávamos finalizando os jogos com a primeira modalidade de jogo e aproveitei a deixa para precisar meu olhar sobre as estruturas do texto. 
sobre os personagens da época de Laclos e coloca em evidência o contexto do século XVIII encenado com papéis trocados $\left({ }^{*}\right)$ : "um jogo onde dois encenam quatro" (MÜLLER, 1997: 230). A Marquesa de Merteuil fora deferida pelo Conde Gercout, que preferiu Madame de Turvel a ela. A pequena Volange, sua sobrinha, está prometida a ele em casamento. Merteuil pede ao Visconde de Valmont que a seduza para vingar-se de Gercout. Gercout havia roubado, de Valmont, Vressac (outra mulher) e Merteuil propõe a "dupla vingança". Visconde de Valmont é mal visto pela sociedade, um conquistador que (segundo o texto) "destrói o coração das mulheres mais soberbas". Já Merteuil é viúva e, graças a hábeis artimanhas, mantém casos amorosos `as escondidas, permanecendo com a honra intacta. Os homens não resistem a seus encantos e são alvo da sua perfídia. Visconde de Valmont é seu amante e amigo. Com ele, Merteuil divide suas conquistas, de maneira que nenhum dos dois exige "exclusividade", o que não evita que tenham ciúmes.

O segundo fragmento do texto de Müller situa o momento em que Valmont apaixonou-se por Turvel, extremamente religiosa, casada e dedicada ao marido (o Senhor Presidente, que também desprezara a Marquesa de Merteuil). Valmont procura Merteuil para que esta o ajude a conquistar Turvel no momento em que rompera um caso amoroso que estava the exigindo a "exclusividade". Merteuil propõe a sedução de Volange e a vingança contra Gercout, mas Valmont prefere a conquista de Turvel e a vingança contra o Senhor Presidente (aos poucos percebe-se que não falam da situação vivida

$\left({ }^{*}\right)$ O texto pode ser avaliado a partir das discussões sobre épico e dramático inauguradas por Szondi. Sarrazac as retoma propondo o hibridismo. Há elementos do dramático (como a relação entre os enunciadores no presente) e do épico (como a presença de dois tempos distantes): "Com o teatro épico, acendemos a uma nova dimensão do espaço e do tempo, a dimensão do distante. E, obviamente, para mostrar estes planos distantes em simultâneo, estas realidades que se cortejam, reduz-se, condensa-se, corta-se" (SARRAZAC, 2002: 38). 
pelos personagens de Laclos, mas dos "números" que serão encenados por

eles com os papéis trocados, de maneira que os dois contextos se articulam).

Os homens estão em guerra. Há apenas a devastação: um cenário

propício, pois as mulheres ficam sós. Merteuil e Valmont concretizam os

planos de vingança. As duas mulheres são destruídas. Valmont interpreta

Turvel enquanto Merteuil assume o personagem masculino. Depois, Merteuil

vive Volange enquanto Valmont a seduz e mata. Turvel (encenada por

Valmont), que se rendera a Valmont (Merteuil), se suicida.

\begin{abstract}
Valmont. Eu dava por acabada sua paixão por mim. Qual a origem deste repentino recrudescer? E com tanta força juvenil! Tarde demais, porém. Não conseguirá mais inflamar meu coração. Nem mais uma vez. Nunca mais. Não lhe digo isso sem pesar, Valmont. Mesmo assim houve minutos, talvez devesse dizer momentos. Um minuto, isso é uma eternidade em que me senti feliz, graças a sua companhia. Estou falando de mim, Valmont. O que sei de seus sentimentos? E talvez fosse melhor falar de minutos nos quais pude usá-lo. Isto é, a sua capacidade de lidar com a minha fisiologia, de sentir alguma coisa que na memória, parece-me um sentimento de felicidade. Não esqueceu como tratar esta máquina. Não retira sua mão. Não que eu sinta alguma coisa por você. É minha pele que se lembra. Ou talvez seja a sua, estou falando da minha pele, Valmont, e simplesmente tanto faz para ela de que modo, em que animal, esta fixado o instrumento de sua volúpia, mão ou garra? Quando fecho os olhos, você é bonito, Valmont. Ou corcunda, se eu desejar. $\mathrm{O}$ privilégio dos cegos. Você tem mais sorte no amor. A comédia dos sintomas the é poupada: você vê o que quer ver. $O$ ideal seria ser cego e surdo-mudo. A paixão das rochas. Eu te assustei, Valmont? Como você é fácil de desanimar. Não o conhecia assim. As damas depois de mim lhe deixaram mágoas? Lágrimas? Será que você tem coração, Valmont? Desde quando? Ou será que sua virilidade estragou com minhas sucessoras? Seu hálito tem sabor de solidão. A sucessora de minha sucessora te mandou passear? O amante abandonado. Não. Não retire sua terna oferta, meu senhor. Eu cumpro. Eu cumpro, em todo caso. Não há sentimentos para temer. Por que deveria te odiar? Nunca te amei... Rocemos nossas peles uma na outra. Ah, a escravidão dos corpos! O martírio de viver e não ser Deus. Ter uma consciência e nenhum poder sobre a matéria. Não se precipite, Valmont. Assim está bem. Sim, sim, sim, sim. Isto foi bem encenado, não? O prazer do meu corpo não me interessa, não sou nenhuma criada de estábulo. Meu cérebro trabalha normalmente. Estou completamente fria, Valmont. Minha vida, minha morte, meu amado. (1)
\end{abstract}

1. MÜLLER, Heiner. Quatro Textos para Teatro: Mauser, Hamlet-máquina, A Missão, Quarteto. São Paulo: Hucitec, 1987, pg. 59. Primeiro fragmento de Quarteto. 


\subsubsection{A Oralidade}

A oralidade do texto é híbrida. O arrebatamento romântico ("Minha vida, minha morte, meu amado") e o discurso existencialista sobre o Nada, a oralidade trágica ("Ah, o Nada em dentro de mim. Ele cresce e me traga. Exige, diariamente, o seu sacrifício") se misturam a um erotismo aos moldes de Sade, conversações cotidianas e um modernismo seco, escatológico: "Quero comer tua merda. Merda por merda. Quero que me cuspa / Quero que mije em mim".

\subsubsection{Relação com a Ação}

A fala tem relação com uma ação que se desenha e com um problema a ser resolvido: Merteuil quer a vingaça contra Gercout enquanto Valmont quer a sedução de Turvel, de maneira que a argumentação gira em torno disto. Por fim, os dois planos são realizados. Quando assumem os personagens, o problema passa a ser a conquista. Valmont precisa fazer com que Turvel aceite dividir seu corpo. Em seguida, o problema passa para a ser vencer o conflito moral para consumar 0 ato sexual com Volange. Volange 0 provoca. Depois de consumado o ato, o problema passa a ser matar. Turvel será castigada. Valmont representa sua morte, morrendo junto com ela. Merteuil fica só. 


\subsubsection{Engajamento, Endereçamento}

Há indicações de engajamento na fala, que se realiza com frêmito, arrebatamento: a ansiedade, a argumentação sobre os planos de vingança, a sedução de Turvel, a morte de Volange, o suicídio. Mesmo quando estão sós a fala é endereçada e escutada.

\subsubsection{Relação com o Passado}

A fala está no presente e traz a memória do passado, que é vivido como ritual, repetição (e reconstrução). Os personagens sabem e aceitam seus destinos. Valmont, não sem conflito: "A fatalidade quase me faz desejar a troca. Sim, eu queria poder trocá-lo, este meu sexo (...) Deve ser a vontade de Deus, não? (...) Esqueçamos o que há entre nós, antes que isso nos una pelo tempo de uma convulsão. Eu sou bom, Marquesa (...)". Turvel sabe que morrerá: "Sabe que me matará antes de...". Merteuil precisa cumpri-lo: "Eu cumpro. De qualquer modo eu cumpro". O destino que precisa suportar é "ser uma mulher": "(VALMONT) Creio que poderia me acostumar, Marquesa, a ser uma mulher / (MERTEUIL) Gostaria de podê-Io". Conta com certa dose de dissimulação: "Sim, isto foi bem encenado, não?".

\subsubsection{Identificação dos Enunciadores}

O primeiro indício para a identificação dos enunciadores são os nomes próprios Valmont e Merteuil. São nobres, cuja preocupação está voltada aos interesses individuais: a manutenção da honra, o acúmulo de 
riquezas, as conquistas amorosas, a salvação da alma. Müller utiliza um jogo de dupla enunciação: é "Merteuil" quem assume as falas de Valmont e Volange (enquanto "Valmont" assume as falas de Turvel). $O$ fato do autor não utilizar "Marquesa" (de Merteuil) e "Visconde" (de Valmont) denota intimidade e os coloca enquanto "homem e mulher".

\subsubsection{A Divisão em Fragmentos}

A partir da organização gráfica, da permanência dos enunciadores e das indicações do autor ("entra Valmont" e "sae Valmont") observamos seis grandes fragmentos (que foram trabalhados fora de ordem, cada qual com partituras físicas diferentes).

1. Primeiro Monólogo de Merteuil (Merteuil sozinha em cena);

2. Reencontro entre Valmont e Merteuil ("Valmont entra") (");

3. Segundo Monólogo de Merteuil ("Valmont sae", Merteuil fica só e fala como Valmont dirigindo a fala para Turvel);

4. Cena de Turvel ("Valmont entra" assumindo as falas de Turvel e Merteuil assume Valmont);

5. Cena da Volange (Merteuil assume Volange e não tem falas, Valmont dirige as falas para Volange e faz comentários sobre Merteuil);

6. Cena Final (Merteuil só assiste, Valmont assume as falas de Turvel dirigidas a Valmont).

(") São as únicas discálias do texto: "Valmont entra", "Valmont sae" e, novamente, "Valmont entra". 


\subsection{A Memorização do Texto Através da Escrita}

La memoria aporta nuevas imágenes y hace surgir un diálogo interno que se mueve más rapidamente que lo que se expresa con palabras.

Knébel

No teatro, eu não faço mais do que me aproximar da compreensão da enorme força que têm as associações de imagens. Aqui há um tesouro infinito de possibilidades.

Meyerhold

Os primeiros estímulos, as vezes estão no jogo, no diálogo, em uma palavra, na sua sonoridade, em uma rubrica, em uma imagem, em um gesto e, outras vezes, na semelhança com a nossa vida, nos nossos sonhos. Entretanto eles são sempre físicos (...) Por isso mesmo é que ficam na nossa memória.

Armando Sérgio da Silva

O "mecanismo associativo espontâneo" implicado na prática com a Memorização Através da Escrita pode ser percebido no dia-a-dia, pois ocorre nas mais diversas situações (ao vermos um filme, dirigirmos o carro, participarmos de uma conversa, lermos um livro, inventarmos uma estória): uma imagem leva `a outra, até que uma delas nos permite estabelecer certa relação com a situação, muitas vezes permeada de afeto, tonicidade. Este mecanismo pode ser utilizado em função de um foco, ou seja, podemos construir um elemento-pivô, um ponto de partida para as associações.

\begin{tabular}{|l|l|l|}
\hline \multicolumn{1}{|c|}{ ASSOCIAÇÕES } & \multicolumn{1}{|c|}{ O JOGO } & \multicolumn{1}{c|}{ IMAGEM ACÚSTICA } \\
\hline A escrita do texto-dado como & Na medida em que temos & A "música das palavras" \\
foco para o mecanismo & regra (repetir o registro & (entrelaçamento dos fonemas) é \\
espontâneo de associação de & escrito) e foco (primeiramente & decantada e fica na memória, nos \\
imagens nas suas diversas & o registro escrito e depois a & libertando do registro escrito. A \\
etapas constituintes: tentativa & imagem acústica), é jogo. O & impressão acústica nos atinge de \\
de escrever o texto de & envolvimento, bem como as & pronto e articula afeto, outras \\
memória, comparação com o & imagens decantadas, & imagens e atividade interna. \\
original e correção. & provocam atividade interna. & \\
\hline
\end{tabular}

(Implicações da Memorização Através da Escrita em nossa experência) 
É disto que se trata quando "escrevemos palavras": o foco se mantém no registro escrito enquanto a imagem acústica (a música do texto) é decantada e nos atinge. Ao escrevermos ou passarmos um encadeamento (acústico) "na cabeça", a imagem ou impressão acústica, instantaneamente, nos engaja em uma atividade interna. Chamamos este registro de "interno" por envolver excitação (tremor, prazer, cansaço, alegria, frustração, paixão, alterações na respiração, na temperatura, no batimento cardíaco, no tônus).

Se tomarmos a experiência com jogos teatrais (e também com a palavra do diretor em meio `a cena), quando uma instrução é proferida, o "organismo total" se mobiliza. Os termos "organismo total" (Spolin), "todo de nossa natureza orgânica" (Knébel), "ação psicofísica" $\left(^{*}\right)$ (Stanislávski) e "ação física" (Grotóvsky), implicam este registro: "El pensamiento se da en el cerebro en una forma muy compleja, abarcando todo lo variado de nuestra naturaleza orgánica" (KNÉBEL, 2002: 63).

A Memorização Através da Escrita é conduzida por etapas: copiar o texto; tentar escrever de memória; perceber e corrigir erros; repetir o procedimento quantas vezes forem necessárias até a desestruturação da escrita (etapa final).

(*) Há uma certa diferenciação no uso dos termos. Ação física implica impulso em Grotóvski. Em Stanislavski, implica um "esquema" que pode converter-se em "psicofísico" na medida em que, ao ater-se "a "entidade física", o ator "evoca" circunstâncias dadas: "Exactamente el mismo valor tiene en el arte del actor la línea de las acciones físicas. El actor, al igual que el pintor, tiene que "poner de pie", "sentar", o "acostar" al modelo" (JIMENEZ, 1990: 301); "Es una acción auténtica, lógicamente fundade, que persigue una concreta finalidad y que en el momento de su ejecución, puede o no convertirse en una acción psicofísica" (JIMENEZ, 1990: 300); "Em suma, o principal, nas ações físicas, não está propriamente nelas, mas naquilo que evocam: condições, circunstâncias propostas, sentimentos" (STANISLAVSKI, 2005: 247). Estamos nos referindo aos últimos trabalhos de Stanislavski, com os textos Tartufo, de Moliére, e Otelo, de Shakespeare, fase que acabou por ser nomeada "Método das Ações Físicas" em oposição 'a primeira fase, nomeada "Linha das Forças Motivas" (foram realizadas experimentações, com textos de Tchékhov e Maeterlinck entre outros, partindo de "processos interiores"). Ver em BONFITTO, Matteo, O Ator-compositor: As Ações como Eixo: de Stanislavski `a Barba, São Paulo: Perspectiva, 2007 e KNÉBEL, María, El Último Stanislavski, Madrid, Fundamentos: 2005. 
Na última etapa da aplicação da Memorização Através da Escrita, a velocidade da "mão que escreve" não acompanha as imagens acústicas e a letra é borrada. Sobram rabiscos, riscos, borrões, bolinhas - medida da memorização, que chamamos "desestruturação da escrita".

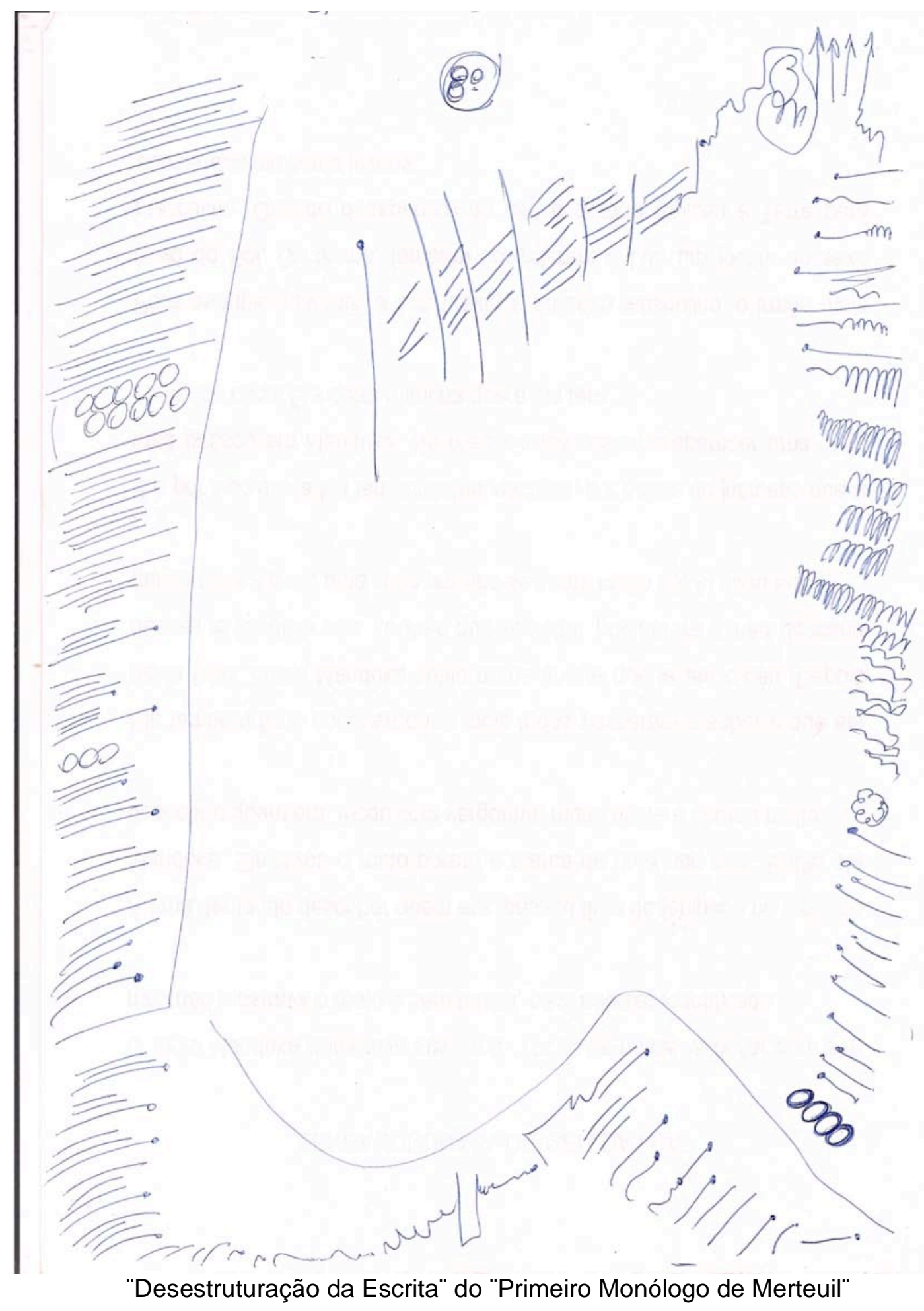




\subsubsection{Despedaçamento, Encadeamento}

A apreensão do sentido pontua uma primeira divisão espontânea em frases (trechinhos). Em seguida, a "desconstrução" da disposição gráfica, física, do registro escrito original, produz subdivisões.

\begin{tabular}{|l|l|}
\hline \multicolumn{1}{|c|}{ REGISTRO GRÁFICO ORIGINAL } & \multicolumn{1}{|c|}{ PRIMEIRA ESCRITA PRÓPRIA } \\
\hline Valmont, eu dava por acabada essa sua paixão por mim. & Valmont, eu dava... \\
& $\begin{array}{l}\text { por acabada... } \\
\text { essa sua paixão por mim. }\end{array}$ \\
\hline
\end{tabular}

As subdivisões instalam um trabalho: a articulação de desvios improvisados mentalmente. Instantaneamente, "imagino" a continuação de uma frase (antes que chegue ao terceiro termo): "Valmont, eu dava... uma surra em você" (por exemplo). Conforme os termos vão sendo memorizados em um encadeamento fixo, vou refazendo mentalmente as imagens, produzindo outras. Ao completarmos a memorização, assumimos o sentido da sentença onde o significante se enquadra.

O significante, por sua natureza, sempre se antecipa ao sentido, desdobrando como que adiante sua dimensão. É o que se vê no nível da frase, quando ela é interrompida antes do termo significativo: Eu nunca..., A verdade é que..., Talvez, também... Nem por isso ela deixa de fazer sentido (...) (1).

Partindo de significantes isolados, de "pedacinhos" do discurso, vou me engajando em "unidades acústicas" cada vez maiores. Escrevo "Valmont" e escuto VAUMOUM. "Eu dava" é EUDÁVA. "Por acabada" é

1. LACAN, Jacques. Escritos, São Paulo: Perspectiva, 1992, pg. 505. 
PURACABÁDA. Com a repetição da escrita, passo a ouvir VAUMONHEU DAVAPURÁCABADESSASUAPAICHÃOUMPURMIIIIIIIM??? A nova imagem implica "embocadura". Aos moldes de um jogador de basquete que mentaliza a cesta antes de jogar a bola, me "escuto", me "vejo" falando, me sinto falando, projeto a fala, "quase" falo. Ou seja, construo a pulsão para a fala, a "vontade de fala" ("macero" a fala antes de ouvir a voz enunciando o texto).

A passagem da disposição gráfica para a produção acústica decanta "pedacinhos", "suturas", "escanções". Ao juntar PÚR e ACABÁDA, ouço "PÚRA" (CABADA), por exemplo. "Pura" associa "pureza”. A junção de PAICHÃUM com PURMIN é "CHÃUMPUR", por exemplo. Uma escanção de "paixão" é "Pai, chão!". A imagem associa outras "na vertical". Conforme as associações, "Pai, chão por mim!" evoca o apelo por estabilidade emocional ou um pedaço de terra. As associações situam um eixo vertical, "reservatório de possíveis", "repertório imagético" (do ator). Assim, começa um trabalho, poderia-se dizer uma "linguagem" própria.

É um outro sentido da palavra linguagem que eu estava tentando fazer-Ihes entender. (...) Trata-se de uma seqüência de ausências e de presenças, ou melhor, da presença sobre fundo de ausência, da ausência constituída pelo fato de uma presença poder existir.

A Memorização Através da Escrita opera um "trabalho", realizado pelo sujeito que apreende, de "memória", o texto-dado: uma produção própria de imagens que verticalmente engendra um desfiladeiro de substituições, um "reservatório de possíveis" a entrar em jogo.

1. LACAN, Jacques. O Seminário, Livro 2: O Eu na Teoria de Freud e na Técnica da Psicanálise. Rio de Janeiro: Jorge Zahar, 1983, pg. 363. 


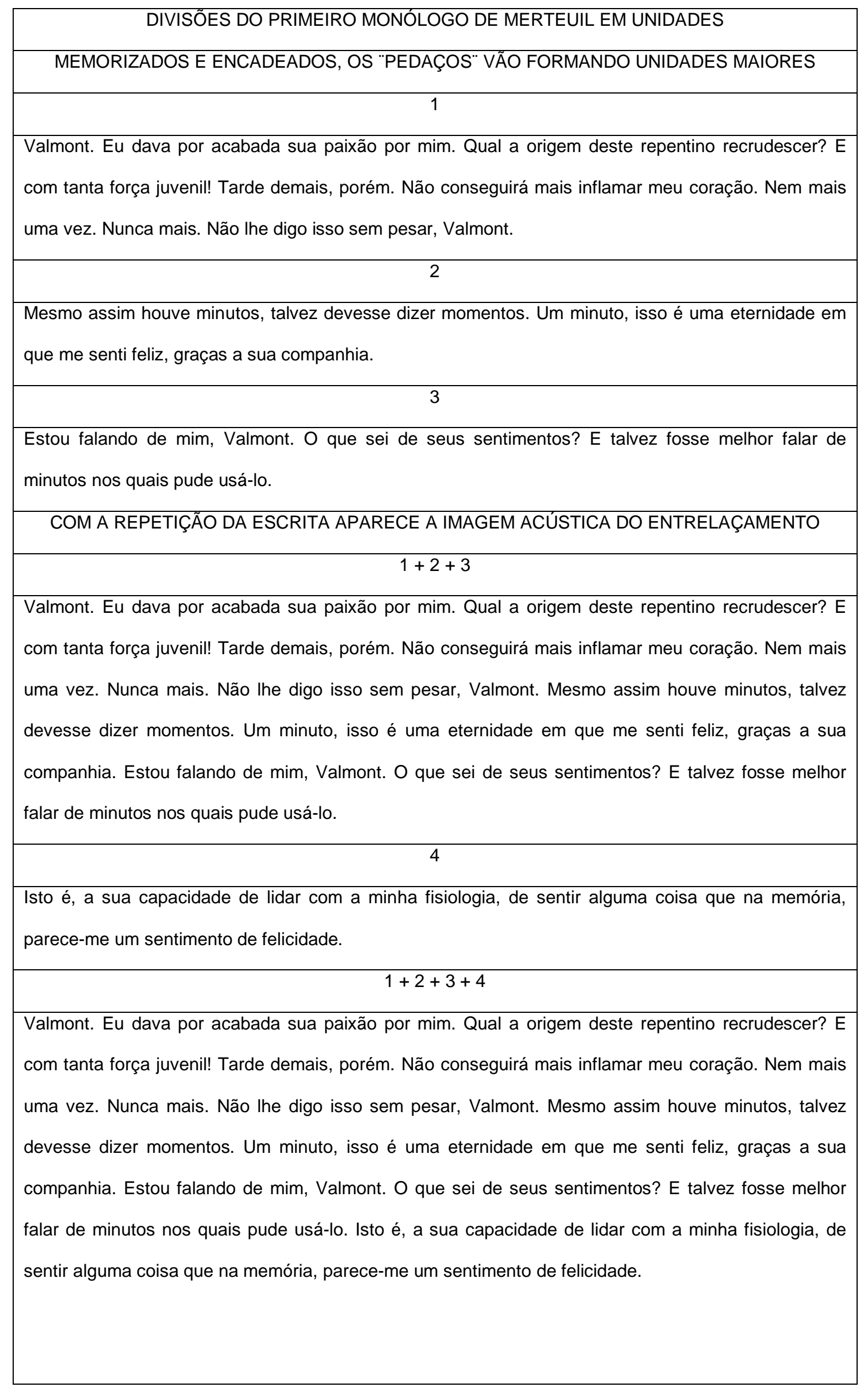




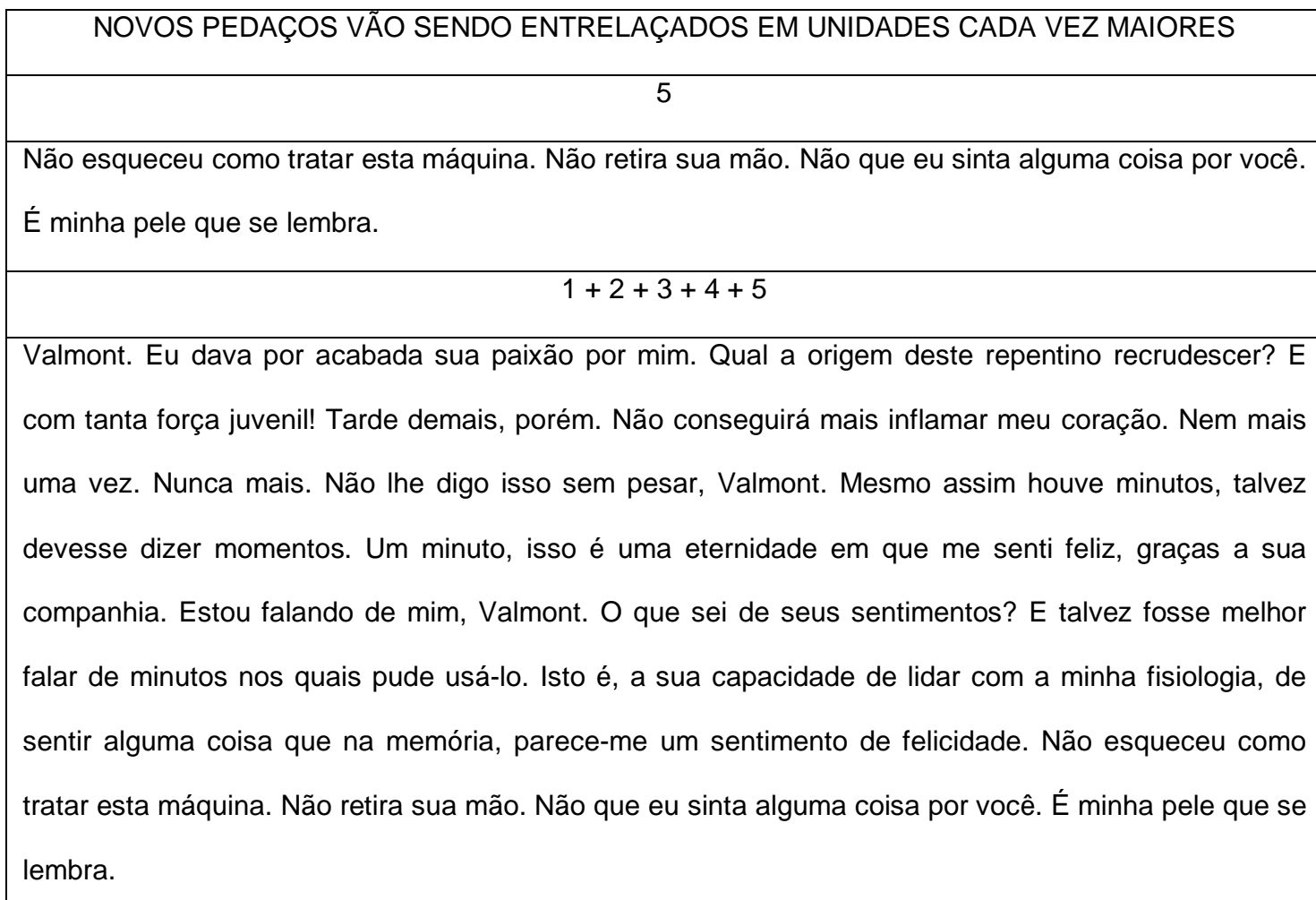
6

Ou talvez seja a sua, estou falando da minha pele, Valmont, e simplesmente tanto faz para ela de que modo, em que animal sta fixado o instrumento de sua volúpia, mão ou garra?

$$
1+2+3+4+5+6
$$

Valmont. Eu dava por acabada sua paixão por mim. Qual a origem deste repentino recrudescer? E com tanta força juvenil! Tarde demais, porém. Não conseguirá mais inflamar meu coração. Nem mais uma vez. Nunca mais. Não lhe digo isso sem pesar, Valmont. Mesmo assim houve minutos, talvez devesse dizer momentos. Um minuto, isso é uma eternidade em que me senti feliz, graças a sua companhia. Estou falando de mim, Valmont. O que sei de seus sentimentos? E talvez fosse melhor falar de minutos nos quais pude usá-lo. Isto é, a sua capacidade de lidar com a minha fisiologia, de sentir alguma coisa que na memória, parece-me um sentimento de felicidade. Não esqueceu como tratar esta máquina. Não retira sua mão. Não que eu sinta alguma coisa por você. É minha pele que se lembra. Ou talvez seja a sua, estou falando da minha pele, Valmont, e simplesmente tanto faz para ela de que modo, em que animal está fixado o instrumento de sua volúpia, mão ou garra?

\section{7}

Quando fecho os olhos, você é bonito, Valmont. Ou corcunda, se eu desejar. O privilégio dos cegos. Você tem mais sorte no amor. A comédia dos sintomas lhe é poupada: você vê o que quer ver. O ideal seria ser cego e surdo-mudo. 
$1+2+3+4+5+6+7$

Valmont. Eu dava por acabada sua paixão por mim. Qual a origem deste repentino recrudescer? E com tanta força juvenil! Tarde demais, porém. Não conseguirá mais inflamar meu coração. Nem mais uma vez. Nunca mais. Não lhe digo isso sem pesar, Valmont. Mesmo assim houve minutos, talvez devesse dizer momentos. Um minuto, isso é uma eternidade em que me senti feliz, graças a sua companhia. Estou falando de mim, Valmont. O que sei de seus sentimentos? E talvez fosse melhor falar de minutos nos quais pude usá-lo. Isto é, a sua capacidade de lidar com a minha fisiologia, de sentir alguma coisa que na memória, parece-me um sentimento de felicidade. Não esqueceu como tratar esta máquina. Não retira sua mão. Não que eu sinta alguma coisa por você. É minha pele que se lembra. Ou talvez seja a sua, estou falando da minha pele, Valmont, e simplesmente tanto faz para ela de que modo, em que animal está fixado o instrumento de sua volúpia, mão ou garra? Quando fecho os olhos, você é bonito, Valmont. Ou corcunda, se eu desejar. O privilégio dos cegos. Você tem mais sorte no amor. A comédia dos sintomas lhe é poupada: você vê o que quer ver. O ideal seria ser cego e surdo-mudo.

\section{MAIS "PEDAÇOS" SÃO MEMORIZADOS}

8

A paixão das rochas. Eu te assustei, Valmont? Como você é fácil de desanimar. Não o conhecia assim. As damas depois de mim lhe deixaram mágoas? Lágrimas? Será que você tem coração, Valmont? Desde quando?

\section{9}

Ou será que sua virilidade estragou com minhas sucessoras? Seu hálito tem sabor de solidão. A sucessora de minha sucessora te mandou passear? O amante abandonado.

10

Não. Não retire sua terna oferta, meu senhor. Eu cumpro. Eu cumpro, em todo caso. Não há sentimentos para temer. Por que deveria te odiar? Nunca te amei... Rocemos nossas peles uma na outra. Ah, a escravidão dos corpos! O martírio de viver e não ser Deus. Ter uma consciência e nenhum poder sobre a matéria.

11

Não se precipite, Valmont. Assim está bem. Sim, sim, sim. Isto foi bem encenado, não? O prazer do meu corpo não me interessa, não sou nenhuma criada de estábulo. Meu cérebro trabalha normalmente. Estou completamente fria, Valmont. Minha vida, minha morte, meu amado. 
EM SEGUIDA SÃO INTEGRADOS `A IMAGEM DO ENCADEAMENTO DO TRECHO TODO

$1+2+3+4+5+6+7+8+9+10+11$

Valmont. Eu dava por acabada sua paixão por mim. Qual a origem deste repentino recrudescer? E com tanta força juvenil! Tarde demais, porém. Não conseguirá mais inflamar meu coração. Nem mais uma vez. Nunca mais. Não Ihe digo isso sem pesar, Valmont. Mesmo assim houve minutos, talvez devesse dizer momentos. Um minuto, isso é uma eternidade em que me senti feliz, graças a sua companhia. Estou falando de mim, Valmont. O que sei de seus sentimentos? E talvez fosse melhor falar de minutos nos quais pude usá-lo. Isto é, a sua capacidade de lidar com a minha fisiologia, de sentir alguma coisa que na memória, parece-me um sentimento de felicidade. Não esqueceu como tratar esta máquina. Não retira sua mão. Não que eu sinta alguma coisa por você. É minha pele que se lembra. Ou talvez seja a sua, estou falando da minha pele, Valmont, e simplesmente tanto faz para ela de que modo, em que animal está fixado o instrumento de sua volúpia, mão ou garra? Quando fecho os olhos, você é bonito, Valmont. Ou corcunda, se eu desejar. O privilégio dos cegos. Você tem mais sorte no amor. A comédia dos sintomas the é poupada: você vê o que quer ver. $\mathrm{O}$ ideal seria ser cego e surdo-mudo. A paixão das rochas. Eu te assustei, Valmont? Como você é fácil de desanimar. Não o conhecia assim. As damas depois de mim Ihe deixaram mágoas? Lágrimas? Será que você tem coração, Valmont? Desde quando? Ou será que sua virilidade estragou com minhas sucessoras? Seu hálito tem sabor de solidão. A sucessora de minha sucessora te mandou passear? $\mathrm{O}$ amante abandonado. Não. Não retire sua terna oferta, meu senhor. Eu cumpro. Eu cumpro, em todo caso. Não há sentimentos para temer. Por que deveria te odiar? Nunca te amei... Rocemos nossas peles uma na outra. Ah, a escravidão dos corpos! O martírio de viver e não ser Deus. Ter uma consciência e nenhum poder sobre a matéria. Não se precipite, Valmont. Assim está bem. Sim, sim, sim, sim. Isto foi bem encenado, não? O prazer do meu corpo não me interessa, não sou nenhuma criada de estábulo. Meu cérebro trabalha normalmente. Estou completamente fria, Valmont. Minha vida, minha morte, meu amado.

\subsubsection{Tensão e Relaxamento}

$\mathrm{Na}$ "tentativa da escrita memorizada" a regra é escrever sem olhar. O que se faz quando a memória não vem? Se improvisa. Em meio aos sussessivos esquecimentos e produção imagética, há um esforço contínuo 
para encontrar as palavras certas. A regra de "escrever sem olhar" colocoume, diversas vezes, diante de um esquecimento absoluto: um momento de suspensão. A sensação é "estar sem chão", o organismo alterado, o coração pulando: o aumento repentino do tônus, o afeto, a ansiedade. Na medida em que as palavras são lembradas, com o domínio da escrita o que se inscreve é o oposto: alegria, entusiasmo, prazer, calma. A ocilação entre estes dois registros produz uma sucessão rítmica entre tensão e relaxamento.

\subsubsection{Ritmo}

As imagens acústicas trazem certas particularidades. A repetição do RÊ em "RÊ (PENTHINU) RÊ (CRUDESCER)", por exemplo, implica dois acentos em um intervalo regular do tempo. Uma seqüência de consoantes, como em "므 (OM) I (AN) I (A) E (ORÇAJUVENIU)", implica "percurssão". Palavras ligadas `a sintaxe inscrevem alterações na velocidade. Um "mas", por exemplo, inscreve uma desaceleração. "Palavras esquecidas" também ganham acento (em detrimento daquelas que facilmente são lembradas).

revesamento entre "tempos fortes e fracos" e "tempos de longa e curta duração" implica ritmo. A Memorização Através da Escrita proporciona a vivência do ritmo implicado no ato de "decantar as imagens acústicas".

(...) Hablo de la influencia directa, a menudo mecânica, por medio del tiempo y del ritmo, sobre nuestro caprichoso, voluntarioso, desobediente y asustadizo sentimento, ese sentimento al que no se le puede ordenar nada que lo ahuyente al inventar apenas forzarlo, y que se oculta en lo más secreto, en donde se vuelve incanzable, ese sentimiento sobre el que hasta hoy no habíamos podido influir sino en forma indirecta, a través de engaños. Ahora, de pronto, hemos encontrado una entrada directa. (1) 


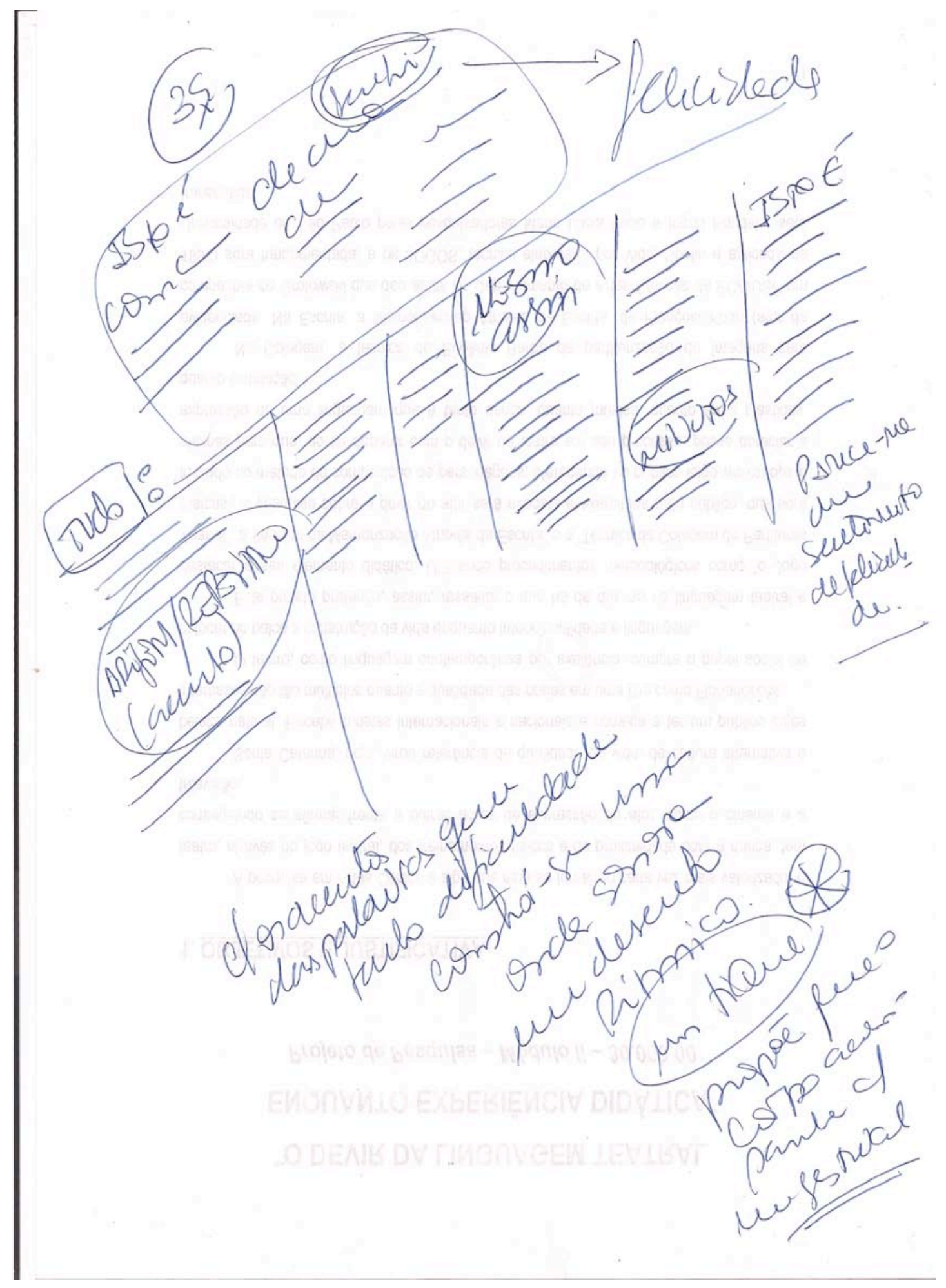

Exemplo 1:

Acentos em palavras que não dizem respeito ao léxico ("mesmo assim" e "isto é"); acento em palavras que foram esquecidas (como "minutos"). Os acentos formam imagem acústica e o corpo acompanha o seu movimento. 


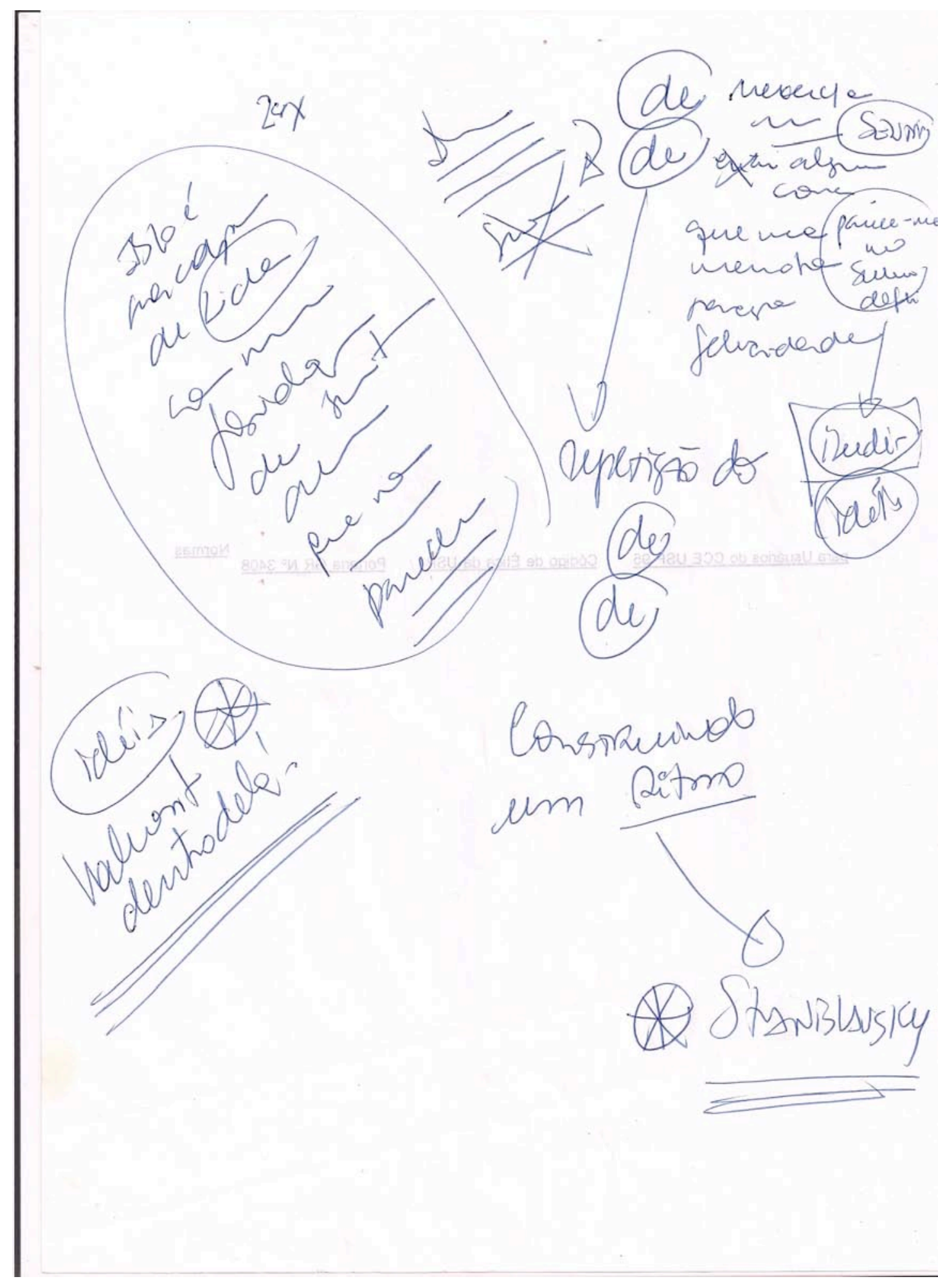

Exemplo 2:

As consoantes iniciais marcam o tempo forte enquanto o resto da palavra "escorrega", "desliza", "se apaga": Sua cap... (escorrega) / de lida... (escorrega) / com... mi... fisiolo.... A repetição de um fonema marca o ritmo: "de"... "de"... 


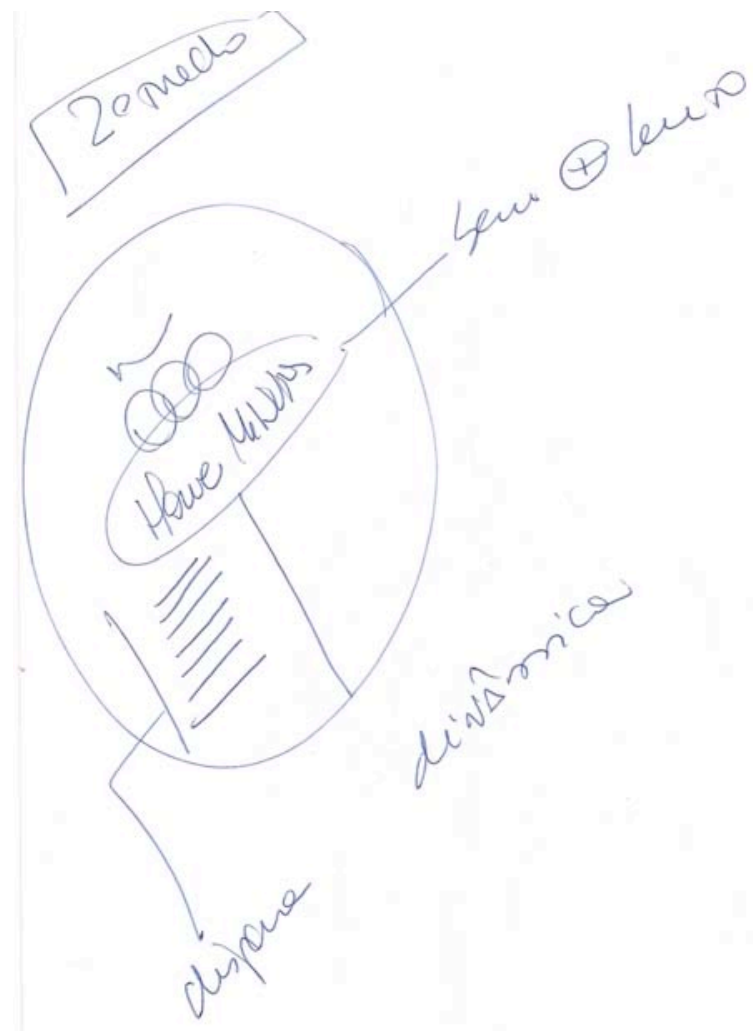

Exemplo 3:

No momento em que uma dúvida aparece (sobre o que deveria ser escrito), a palavra é registrada com lentidão - o que constitui ênfase, acento. Logo que a memória flui, há uma "disparada", uma explosão. O corpo responde organicamente a este movimento.

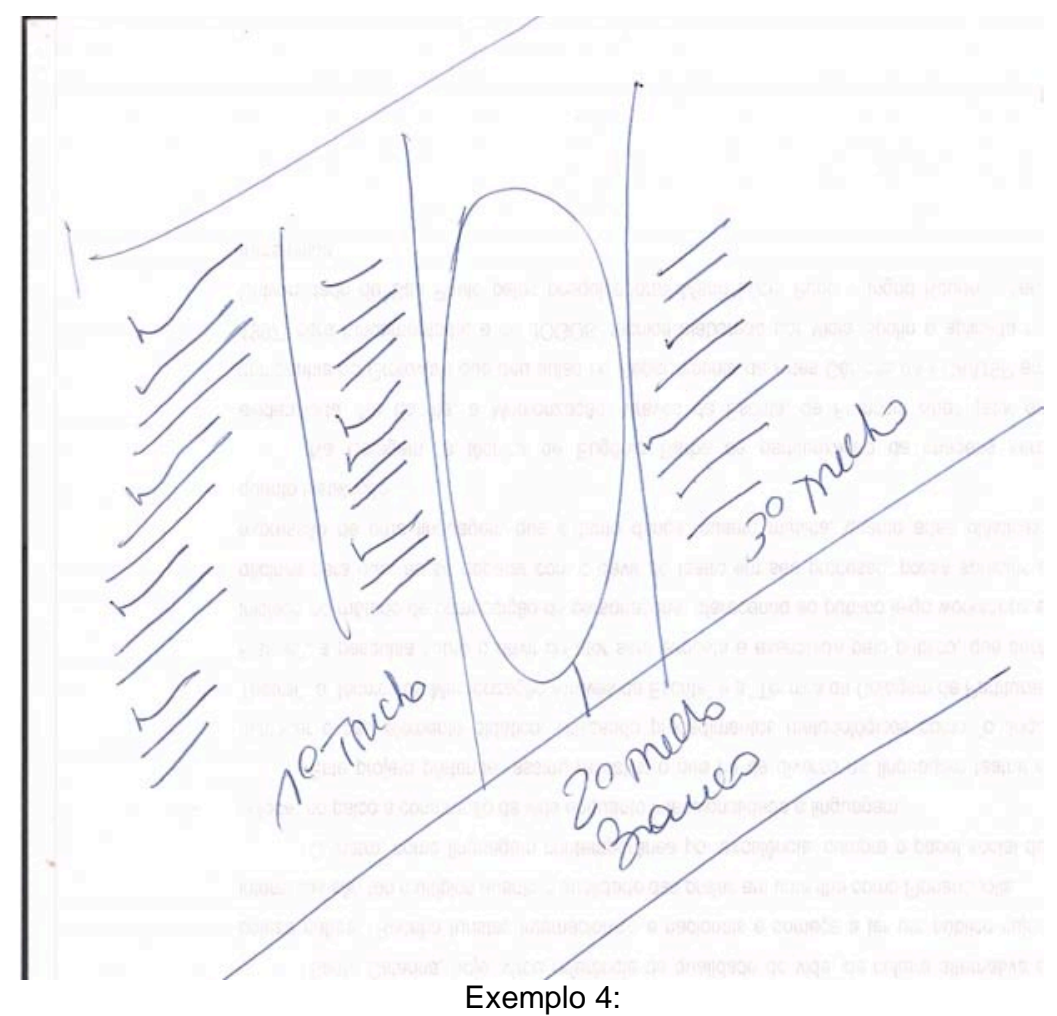

Um momento de "lidar com o esquecimento". Na "escrita memorizada" de todos os trechos juntos, o esquecimento de todo um pedaço formando pausa. Coloquei um círculo no lugar do "trecho esquecido" e continuei. Era um momento em que a memória já estava fluindo: os outros trechos foram lembrados com facilidade, como se percebe pela "caligrafia borrada". 


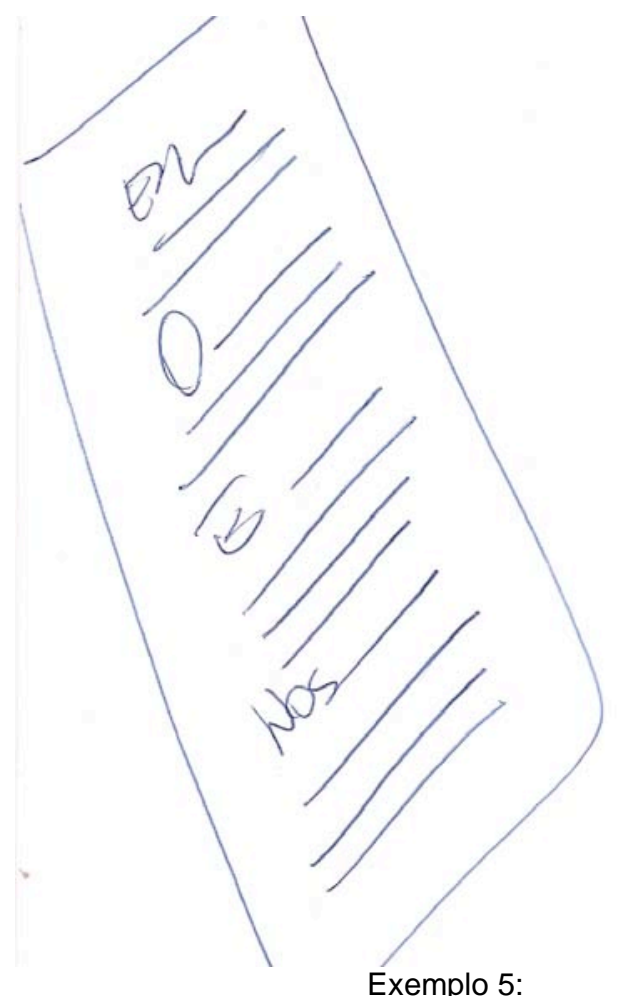

As palavras que ganharam ênfase não dizem respeito ao léxico, mas `a sintaxe: "Estou", "O", "E", "Nos".

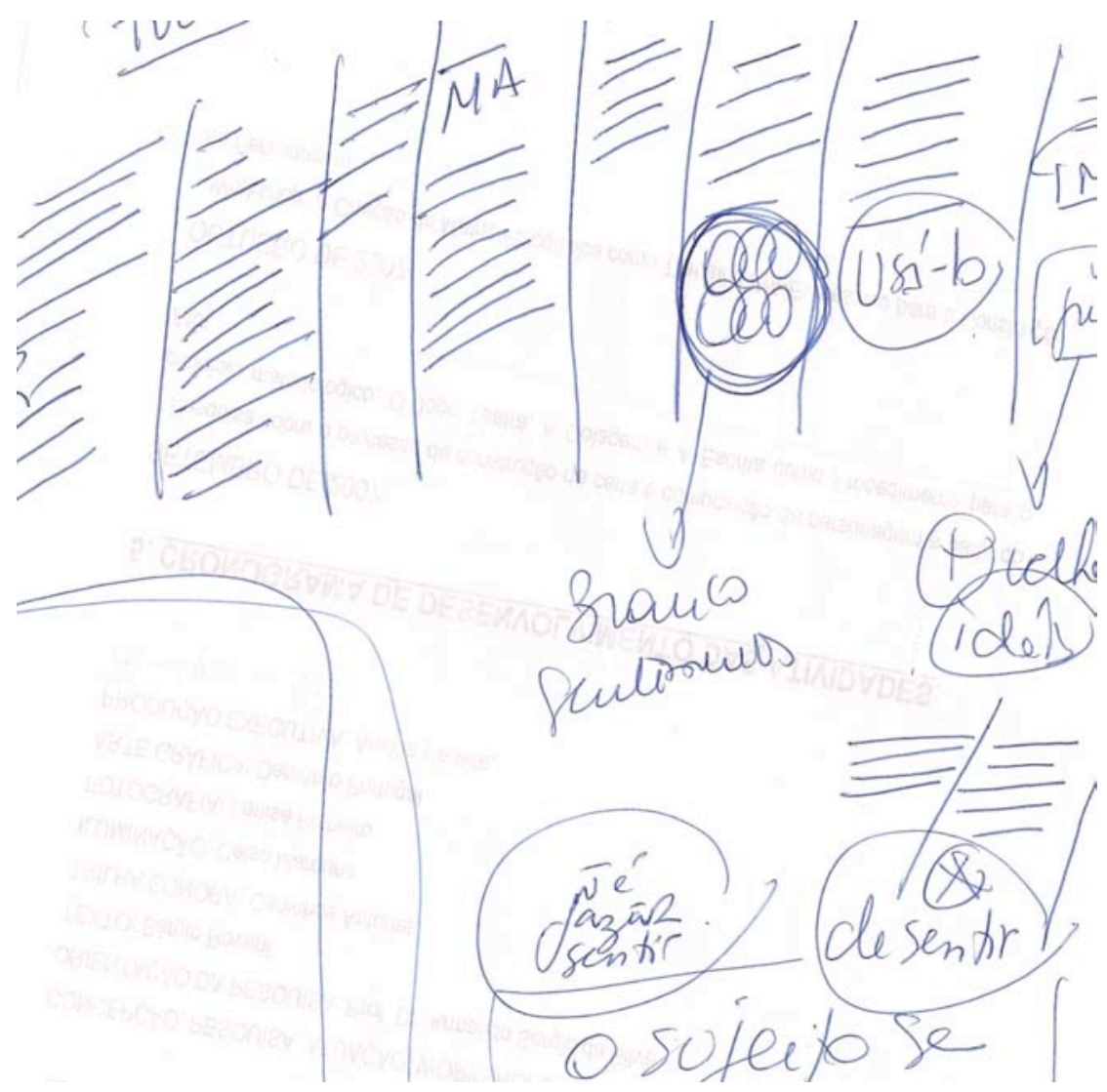

Exemplo 6:

No momento de esquecimento, "branco total": vazio e elaboração de afeto, conflito, sentimento, angústia, ansiedade.

$\mathrm{O}$ organismo responde, se altera. 


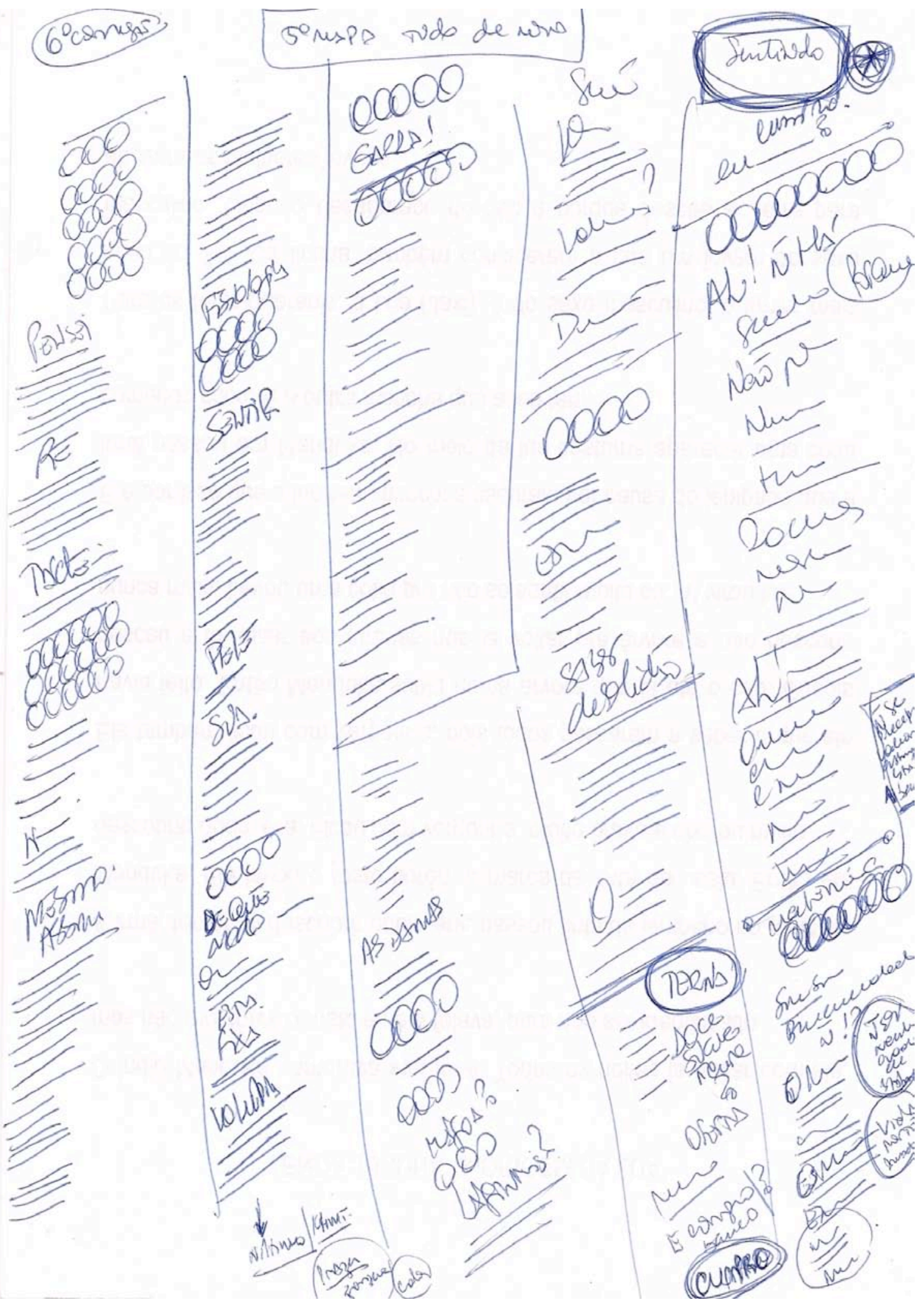

Exemplo 7:

Uma espécie de "matriz rítmica": as palavras que ainda possuem o registro gráfico foram escritas com vagar e ênfase. Os círculos indicam momentos de pausa e tentativa de elaboração do afeto. Os traços marcam momentos de revesamento das imagens acústicas em alta velocidade. A mão que escreve não acompanha e borra a caligrafia. O corpo acompanha as ocilações e vivencia o ritmo. 


\subsubsection{Imagens}

$\mathrm{O}$ ato de escrever evoca imagens. Há um mecanismo associativo espontâneo que se instala. Este mecanismo é propriamente espontâneo. O foco está dividido entre o registro gráfico e a imagem acústica. A imagem acústica é densa. "Partiturizada", encadeia uma ordem fixa e "foca": carrega o corpo. Carrega o corpo através do encadeamento acústico, pelos seus solavancos, percursões, derrapadas e acidentes. As outras imagens (associadas) "aparecem" e se instalam "bem no corpo". De maneira que é perceptível a diferença entre estas duas posições: foco e espontâneo. As associações se instalam de supetão, trazendo surpresa, novidade e a alegria da descoberta. As imagens são associadas a partir de "pedacinhos", "detalhes". É uma produção delicada. Da junçãozinha de um fonema com outro, da particularidade de um ritmo que me lembra algo, evoca uma voz, uma imagem, uma memória. É sinuoso, repentino, escorregadio. As imagens passam, atravessam. Há o estilhaçamento de imagens exercitadas no corpo. Evocam a ficção (onde está a "situação de Merteuil"). Evocam, também, uma atividade cênica, antigos repertórios, a presença do público, a relação com o fazer (o contexto da atriz). Constróem vibrações físicas. Vivências. Há uma vivência destas imagens. $\mathrm{O}$ afeto e o "efeito" destas imagens.

\begin{tabular}{|c|l|l|}
\hline TRECHO & TENTATIVA & \multicolumn{1}{|c|}{ IMAGENS ASSOCIADAS DURANTE A ESCRITA } \\
\hline 1 & Primeira & $\begin{array}{l}\text { Sou puta / Mulher acabada / A paixão é gente / Alegria / Jogo ou } \\
\text { tristeza / Ela está irredutível / Ela está triste. }\end{array}$ \\
\hline 1 & Segunda & Alegria. \\
\hline 1 & Terceira & Susto / Eles brigaram / Muita magoa / Está relembrando. \\
\hline 1 & Quarta & Nunca mais / O "jogo com o jornal" (repertório de prática anterior). \\
\hline
\end{tabular}




\begin{tabular}{|c|c|c|}
\hline 1 & Quinta & A mágoa dele / "Eu" (dava...). \\
\hline 1 & Sexta & Eu e PC (primeiro namorado). Eu muito fria. Término de relação. \\
\hline 2 & Primeira & Olhar para o público. \\
\hline 2 & Segunda & - \\
\hline 2 & Terceira & - \\
\hline 2 & Quarta & - \\
\hline 3 & Primeira & Ela se corrige (preciso falar de outra coisa)... duas vezes. \\
\hline 3 & Segunda & - \\
\hline 3 & Terceira & "Minuta" (de contrato). \\
\hline 3 & Quarta & Ôôôôôôôôô / Interrupção. \\
\hline 123 & Primeira & - \\
\hline 123 & Segunda & Momento de virada / Sensação de raiva. \\
\hline 123 & Terceira & Desvios. \\
\hline 4 & Primeira & - \\
\hline 4 & Segunda & Valmont dentro dela. \\
\hline 4 & Terceira & Desejo de sentir felicidade. \\
\hline 1234 & Primeira & Acento, tique. \\
\hline 1234 & Segunda & Confusão de sentimentos. \\
\hline 5 & Primeira & Um sujeito cindido. Um rosto. Eu e Valmont. \\
\hline 5 & Segunda & $\begin{array}{l}\text { "Uma mão invisível empurra a minha nuca. Invisível e gigantesca. } \\
\text { Parte dos olhos de Deus" (fragmento de poema próprio de 1989). }\end{array}$ \\
\hline 12345 & & $\begin{array}{l}\text { Um tom grandiloqüênte, trágico / A cadência, a repetição do som "c" } \\
\text { trouxe a associação com "opaco" / Na correção de "mexer" para } \\
\text { "lidar", o "mexer" evocou a sensação de uma "mão que mexe" e } \\
\text { excita o corpo, um balancinho / Valmont é ela. }\end{array}$ \\
\hline 6 & & - \\
\hline 123456 & Primeira & $\begin{array}{l}\text { Ele como objeto / A mistura de identidade de um e de outro / Mão } \\
\text { ou garra como instrumento do jogo. }\end{array}$ \\
\hline 123456 & Segunda & Imagens de Klimt / Um sentimento: enfermidade ou pureza? \\
\hline 123456 & Terceira $\mathrm{t}$ & Sentir $\mathrm{x}$ anestesia / Perversão $\mathrm{x}$ pureza. \\
\hline 7 & Primeira & Mito da Alma / Psiqué e Eros. \\
\hline 7 & Segunda & - \\
\hline 7 & Terceira & Cega / Parar de falar não é possível / Para a cega que ela é / Está \\
\hline
\end{tabular}




\begin{tabular}{|c|c|c|}
\hline & & construindo Valmont no momento. \\
\hline 1234567 & Primeira & Sentir-se feliz / "O Marinheiro" (peça de teatro encenada em 1995). \\
\hline 8 & Primeira & "Louca de pedra" (expressão) / Tudo é possível no sonho. \\
\hline 8 & Segunda & Brincando com ele / Menina Ofélia \\
\hline 8 & Terceira & - \\
\hline 9 & Primeira & - \\
\hline 9 & Segunda & - \\
\hline 9 & Terceira & - \\
\hline 10 & Primeira & - \\
\hline 10 & Segunda & - \\
\hline 10 & Terceira & - \\
\hline 10 & Quarta & Vai dando uma zonzeira, um tremor... \\
\hline 11 & Primeira & - \\
\hline TUDO & Primeira & Fui até aqui: solidão. \\
\hline TUDO & Segunda & $\begin{array}{l}\text { Gelo. Medo. Zonzeira / Susto com a descoberta / Estragou / } \\
\text { Defende / Eu (Rejane) quero dizer isto. }\end{array}$ \\
\hline TUDO & Terceira & Fico encantada com o texto / "Dar um trato" / Orgasmo. \\
\hline TUDO & Quarta & Valmont é um outro que tem dentro dela. \\
\hline TUDO & Quinta & - \\
\hline
\end{tabular}

Registro por escrito das imagens associadas durante a Memorização Através da Escrita

Imagens diferentes são evocadas a cada "tentativa de escrita memorizada" (o que implica a condição do "instantâneo", do "espontâneo", em função de outros elementos que situam o foco). A associação é "instantânea". Quando nos damos conta "já aconteceu". María Knébel situa um mecanismo associativo que implica o "ver mentalmente". Ela utiliza o termo imaginação para referir-se a três momentos do processo de criação: os primeiros contatos com o texto, a maturação da idéia sobre a obra e o momento do ator em cena. Nos três momentos ocorrem associações "inesperadas". 
Se dan entonces complicadas e inesperadas associaciones. De pronto podemos ver alguna pintura o escuchar una música determinada; imaginamos un paisaje que vimos en la infancia... (1)

As definições de "imaginação" implicam:

(..) a faculdade de evocar imagens de objetos que já foram percebidos; faculdade de formar imagens de objetos que não foram percebidos, ou de realizar novas combinações de imagens; faculdade de criar mediante a combinação de idéias. (2)

O termo "visualização", utilizado por Kusnet, também implica o "ver mentalmente": "Desta maneira você constatará que imaginar (como você acaba de fazer) significa ver as coisas ausentes, inexistentes ou irreais, contanto que as veja mentalmente" (KUSNET, 1987: 39). A visualização não é "passiva" (o ator não visualiza algo "fora" para depois representá-lo). O tempo do jogo é o aqui e agora e a visualização se dá, propriamente, como registro físico. A definição de Santo Agostinho parece fazer eco `a prática:

As imagens são originadas por coisas corpóreas e por meio das sensações: estas, uma vez percebidas, podem ser facilmente lembradas, distinguidas, multiplicadas, invertidas, recompostas do modo que mais agrade ao pensamento. (3)

A prática com a Memorização Através da Escrita aponta para uma intimidade entre a imagem acústica e o corpo (o que se vê e ouve é percebido como registro físico). A “instantaneidade“ implica uma posição na estrutura do jogo. Há produção imagética: reservatório de "elementos distingüíveis", passíveis de serem "lembrados, invertidos, recompostos".

1. KNÉBEL, María. La Poética de la Pedagogía Teatral. Madri: Ed. Fundamentos, 2005. pg. 111.

2. HOLANDA, Buarque. Novo Dicionário da Língua Portuguesa. Rio de Janeiro: Nova Fronteira, 1986, pg. 918.

3. ABBAGMANO, Nicola. Dicionário de Filosofia. São Paulo: Martins Fontes, 2007, pg. 621. 




Exemplo 1:

$\mathrm{Na}$ escrita do nome Valmont, a imagem de um "susto" articula "repentino" (ganhou ênfase com a correção de "tamanho").

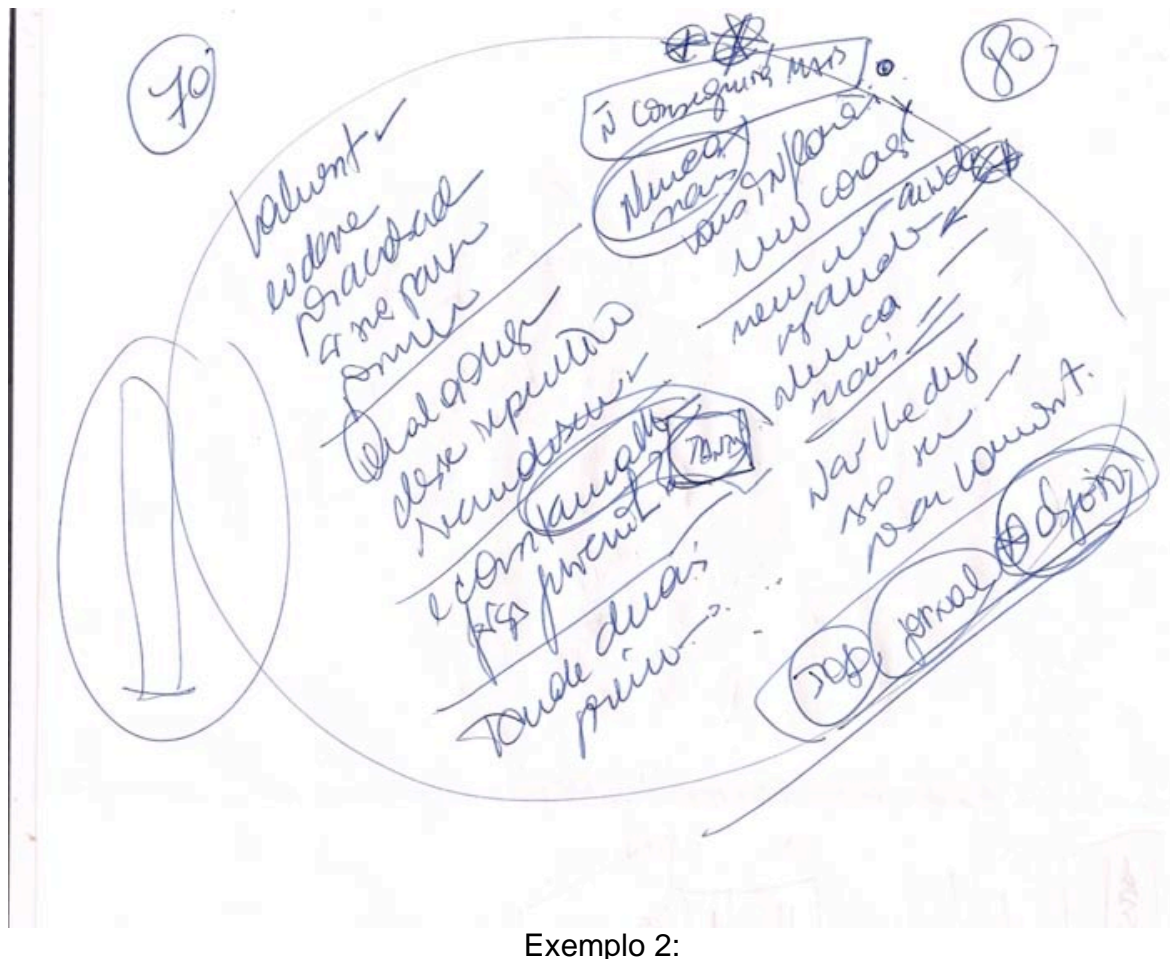

Um "ritmo quebrado" associou a imagem de um objeto: primeiramente um jornal, (já estava em meu repertório, utilizado anteriormente em um laboratório) e, depois, uma carta. 




Exemplo 3:

A memorização já estava adiantada. O encadeamento das imagens acústicas ganhou velocidade e engajou o corpo. Foi possível sentir o ritmo corpóreo. A caligrafia foi borrada. Ficaram apenas duas sílabas (que ganharam ênfase): o "re" de "repentino recrudescer" e o "eu" (que mais tarde voltei a esquecer). A correção do "eu" associou uma imagem do passado, um rompimento de um relacionamento antigo, um momento de minha estória de vida.

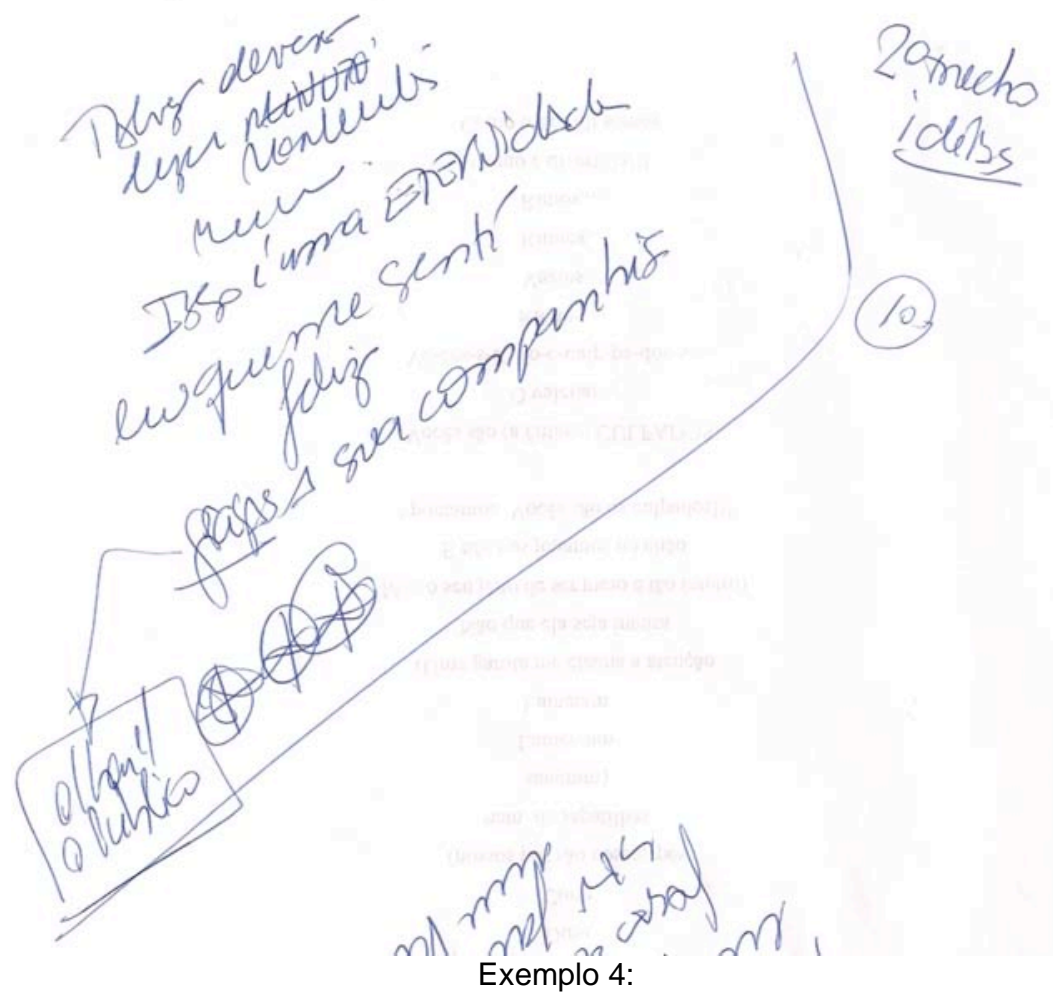

Quando escrevi "graças a sua companhia" associei a idéia de "olhar para o público". Mais tarde, em jogo de enunciação, trabalhei com a idéia de "olhar ou não olhar" para Valmont (que estaria fora de cena) e de "olhar ou não olhar" para o objeto que eu tinha nas mãos (a carta). Na segunda modalidade de jogo o "olhar para o público" foi utilizado. 
$\mid$



Exemplo 5:

A troca insistente de "minutos" para "momentos" asssociou a imagem de uma "ocilação", um "vacilo", junto `a "sensação de dúvida". Esta imagem apareceu em cena quando Merteuil conclui que Valmont foi abandonado. A troca de "momentos" para "minutos" associou "minuta" (de contrato), que associou "tribunal". Apareceu em cena relacionada a outras frases: "Eu cumpro. De qualquer modo eu cumpro" e "A quatro dias de Paris, um buraco de lama que pertence a minha família".

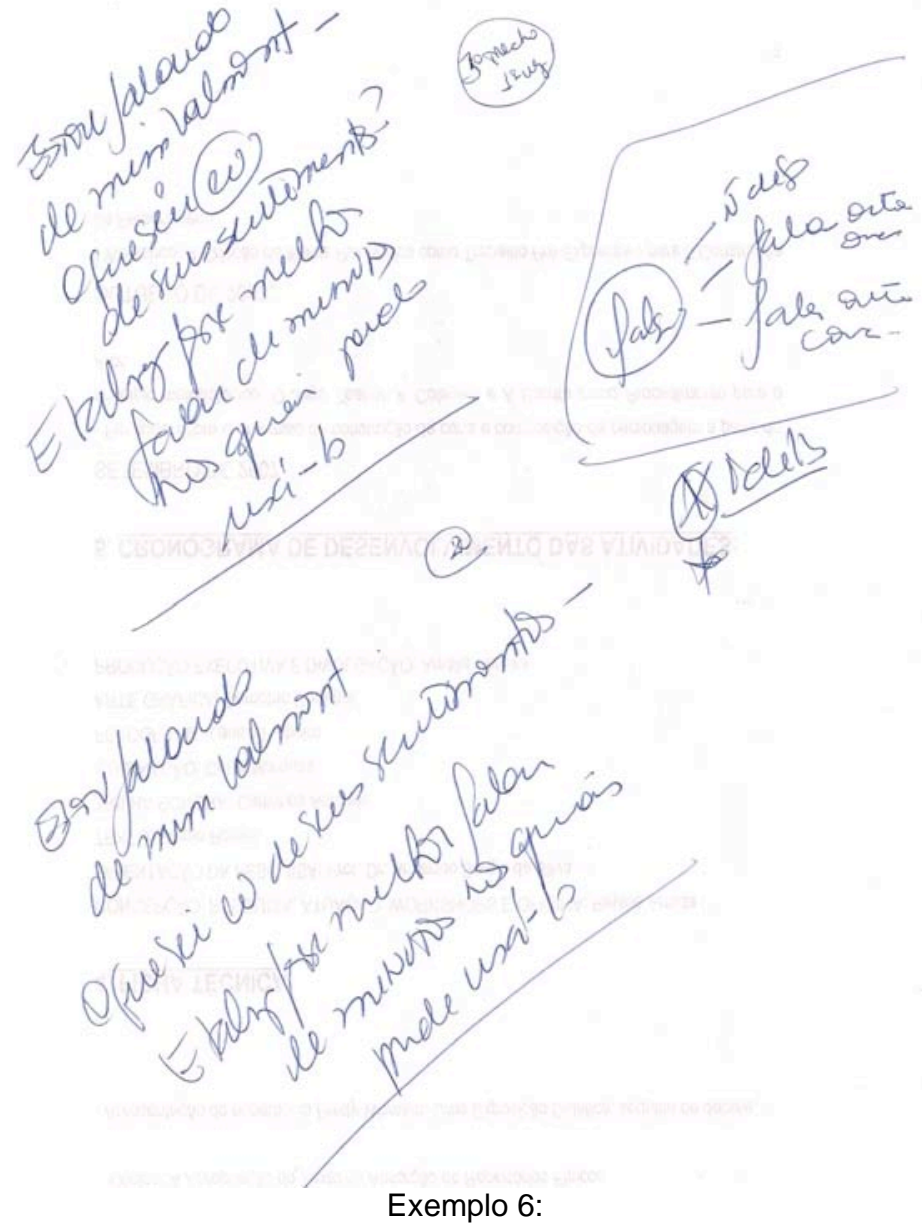

A idéia de "corrigir-se ou refletir sobre qual assunto seria melhor falar" associou outra: "ela conta com a confirmação dele - que estaria, fora de cena, ouvindo". Esta imagem não foi utilizada. 


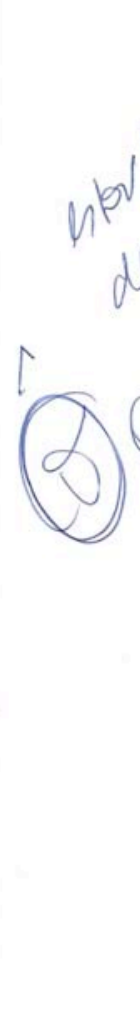

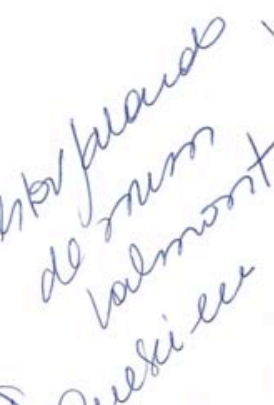
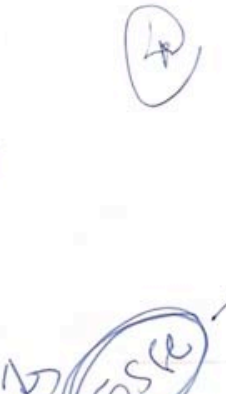

i $(6)$
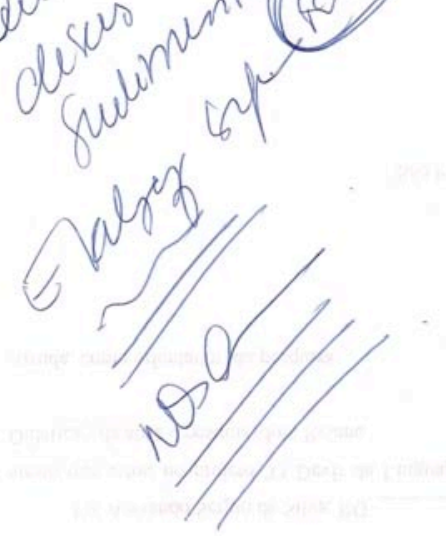

\section{Exemplo 7:}

O "Ô" (de "o que sei eu de seus sentimentos") foi esquecido. A correção associou uma imagem "meio grosseira", um certo "peso do corpo para baixo", que voltou, na posição do espontâneo, no jogo de enunciação com qualidades físicas (especificamente com a qualidade "oleoso").

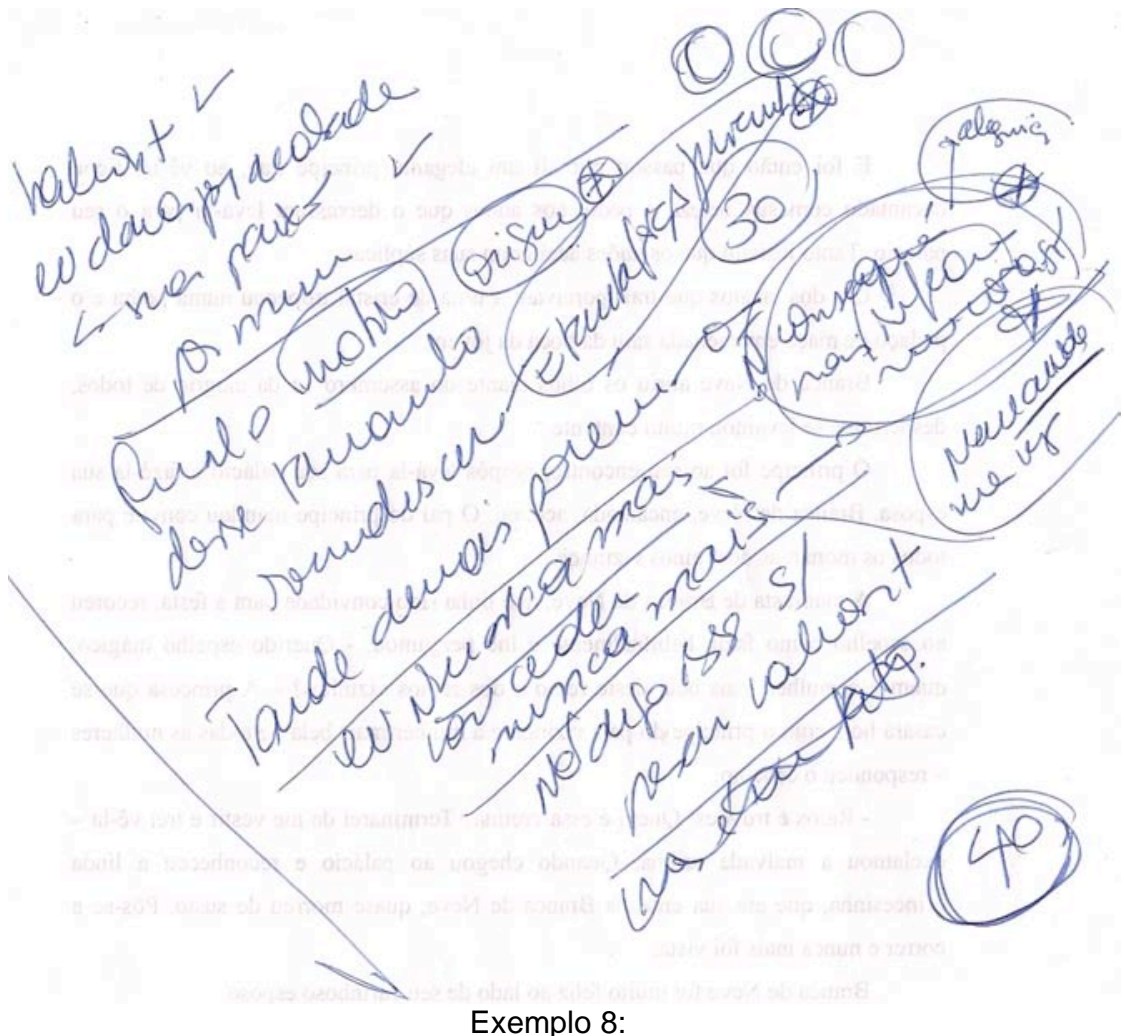

A correção de "Não conseguirá mais inflamar meu coração" associou a imagem de "alegria". 


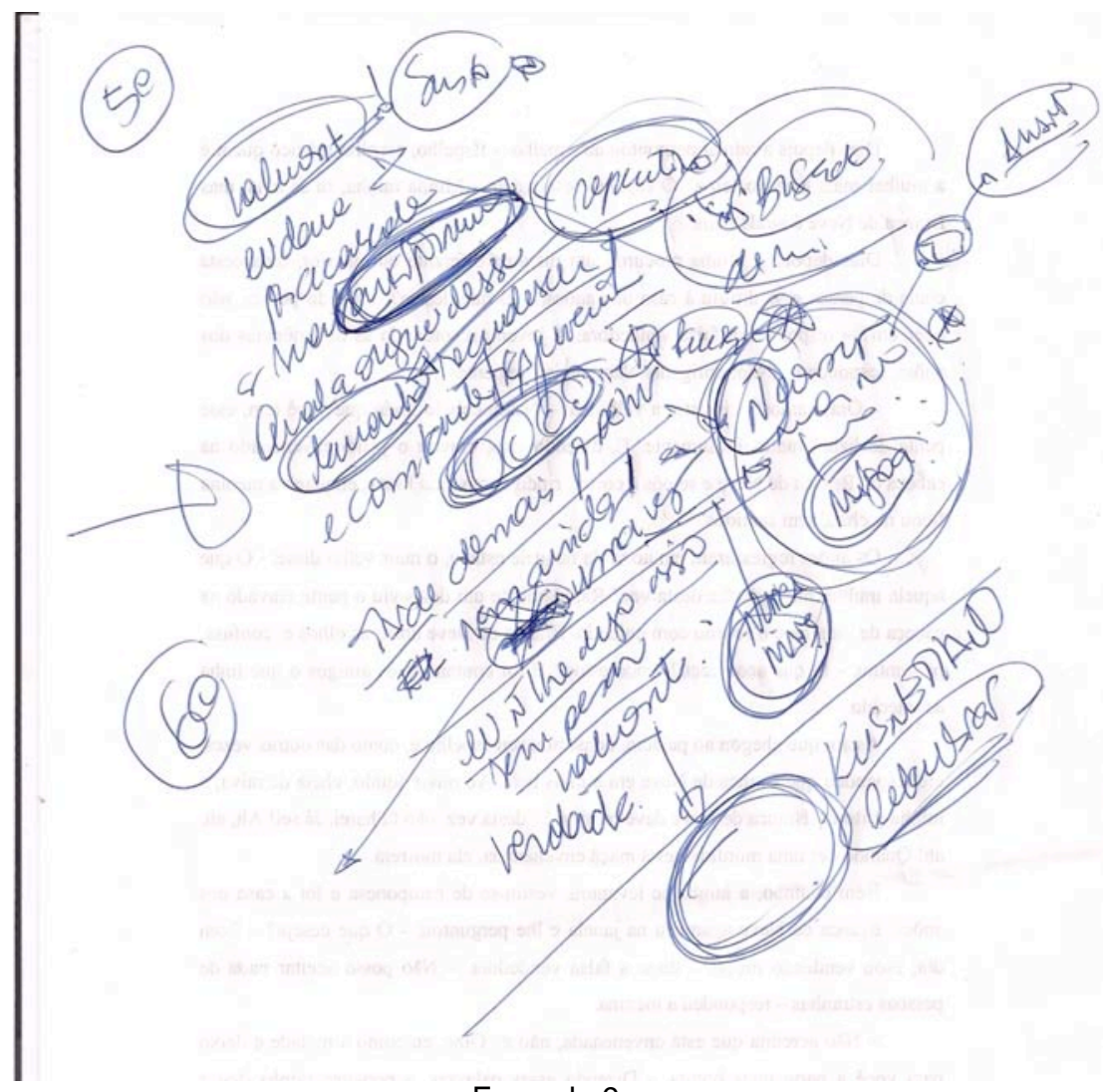

Exemplo 9:

A pausa depois de "tanta força juvenil" associou a imagem de "mágoa", articulada, por sua vez, ‘a idéia de que "eles haviam brigado" e o verbo "relembrar".

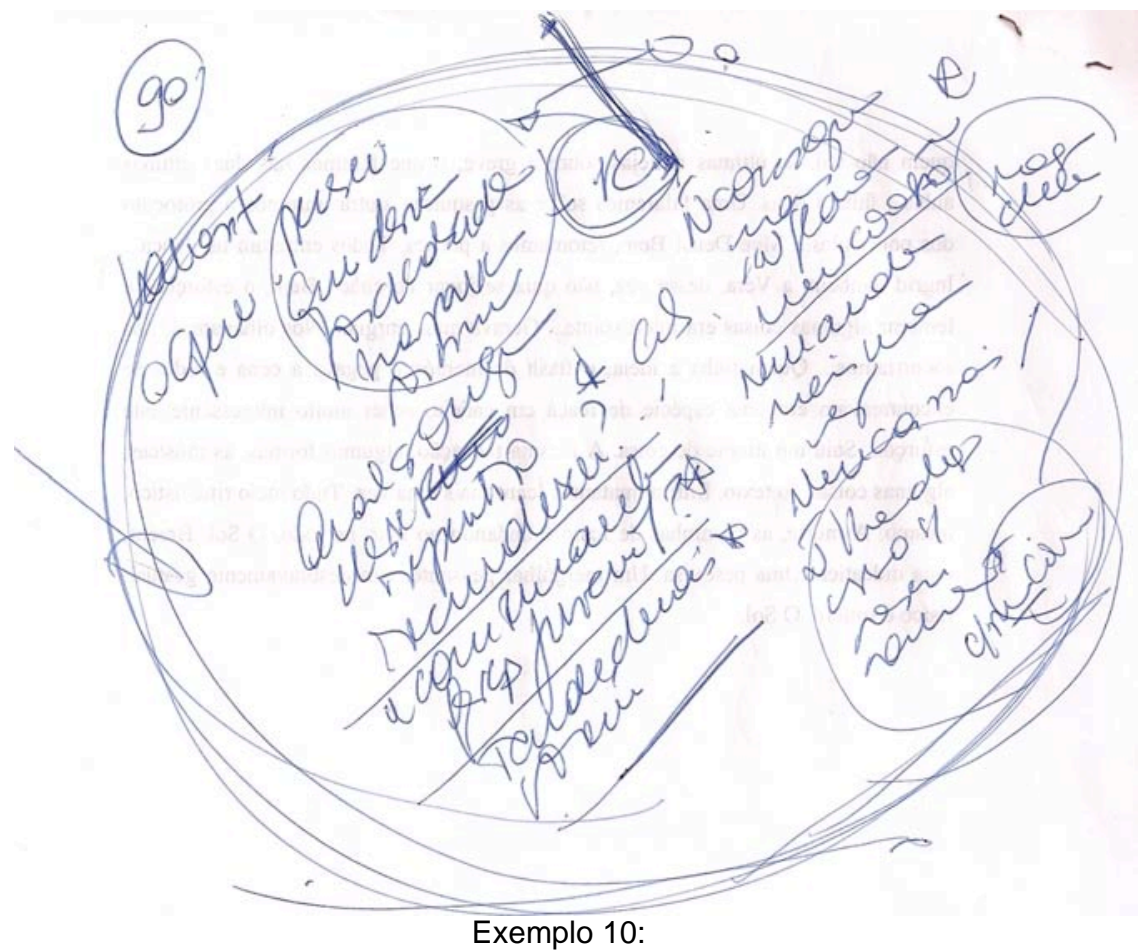

A correção de "Não conseguirá mais inflamar meu coração" associou a idéia de "mágoa dele". Antes havia um Valmont "alegre" e "juvenil" e, agora, a imagem de um Valmont "acabado" e "fraco". Estas imagens foram deixadas "fora do foco". Jogos de enunciação também articularam a imagem de dois Valmonts: aquele representado por Merteuil (jovial e alegre) e o que se reencontra com ela (sem ânimo para encenar a "Caçada `a Virgem"). 


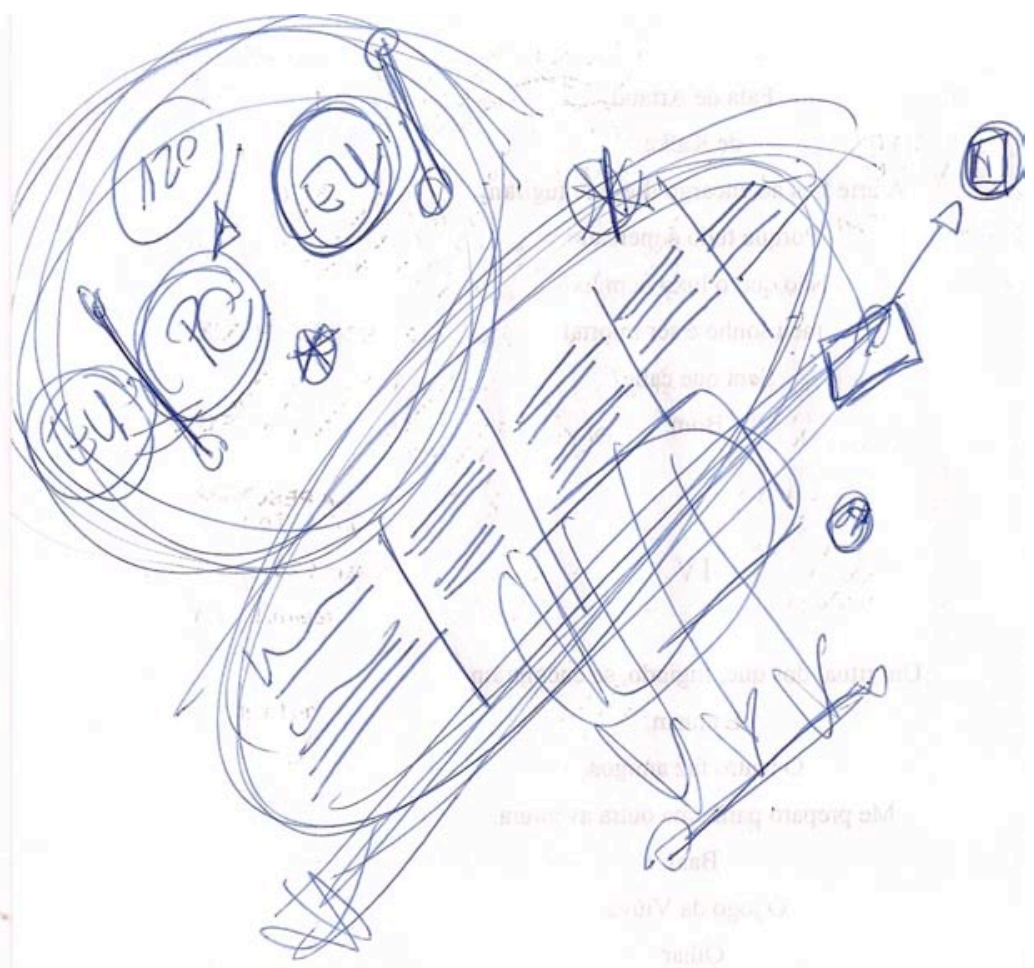

Exemplo 11:

Foi associada a imagem de um revezamento: "Quem está acabado"? Ora "eu", ora "ele".

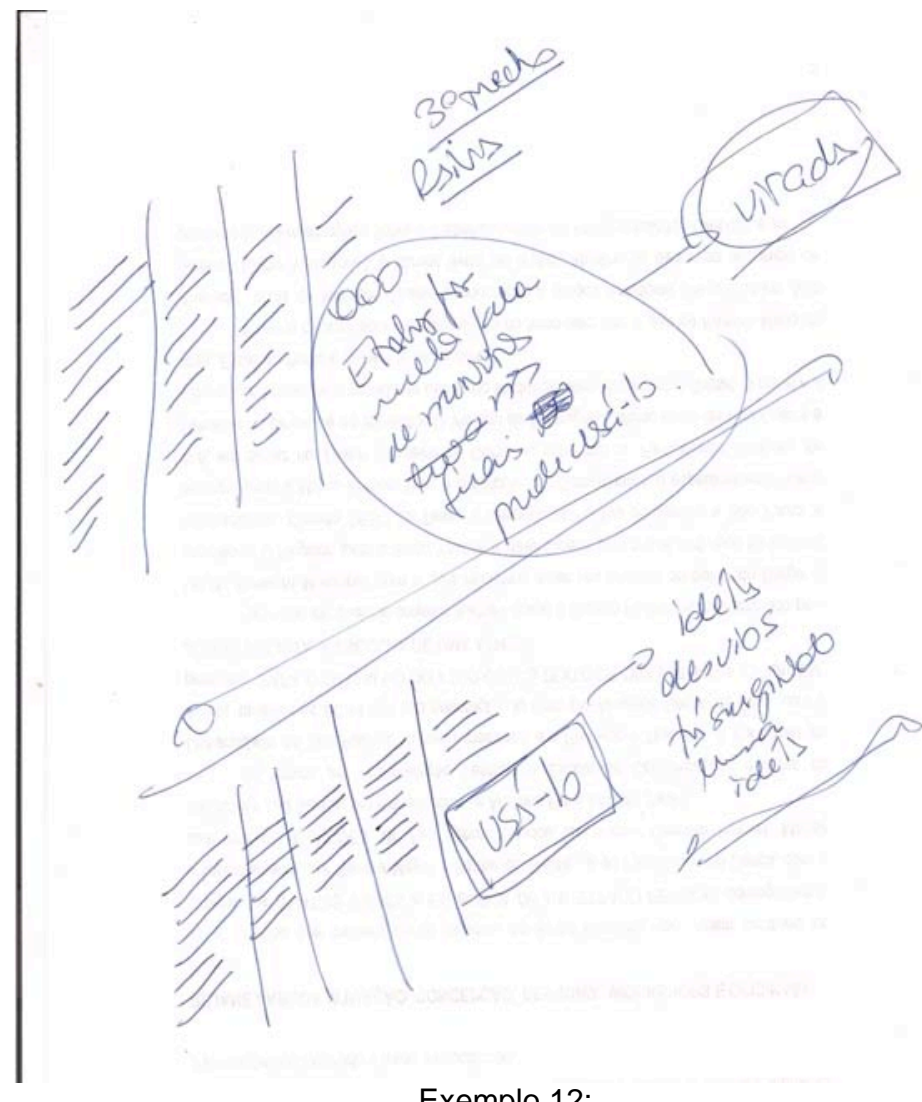

Exemplo 12:

A memorização estava adiantada. A frase " $E$ talvez fosse melhor falar de minutos em que pude usá-Io" articulou a idéia de "raiva". Na segunda vez, o "usá-lo", única palavra graficamente estruturada, ganhou ênfase e, seguida de pausa, potencializou, ainda mais, a idéia de "raiva". A imagem implica "o corpo" que, com raiva, registra marcas na folha de papel (enquanto é conduzido pela imagem acústica que se desenrola). 


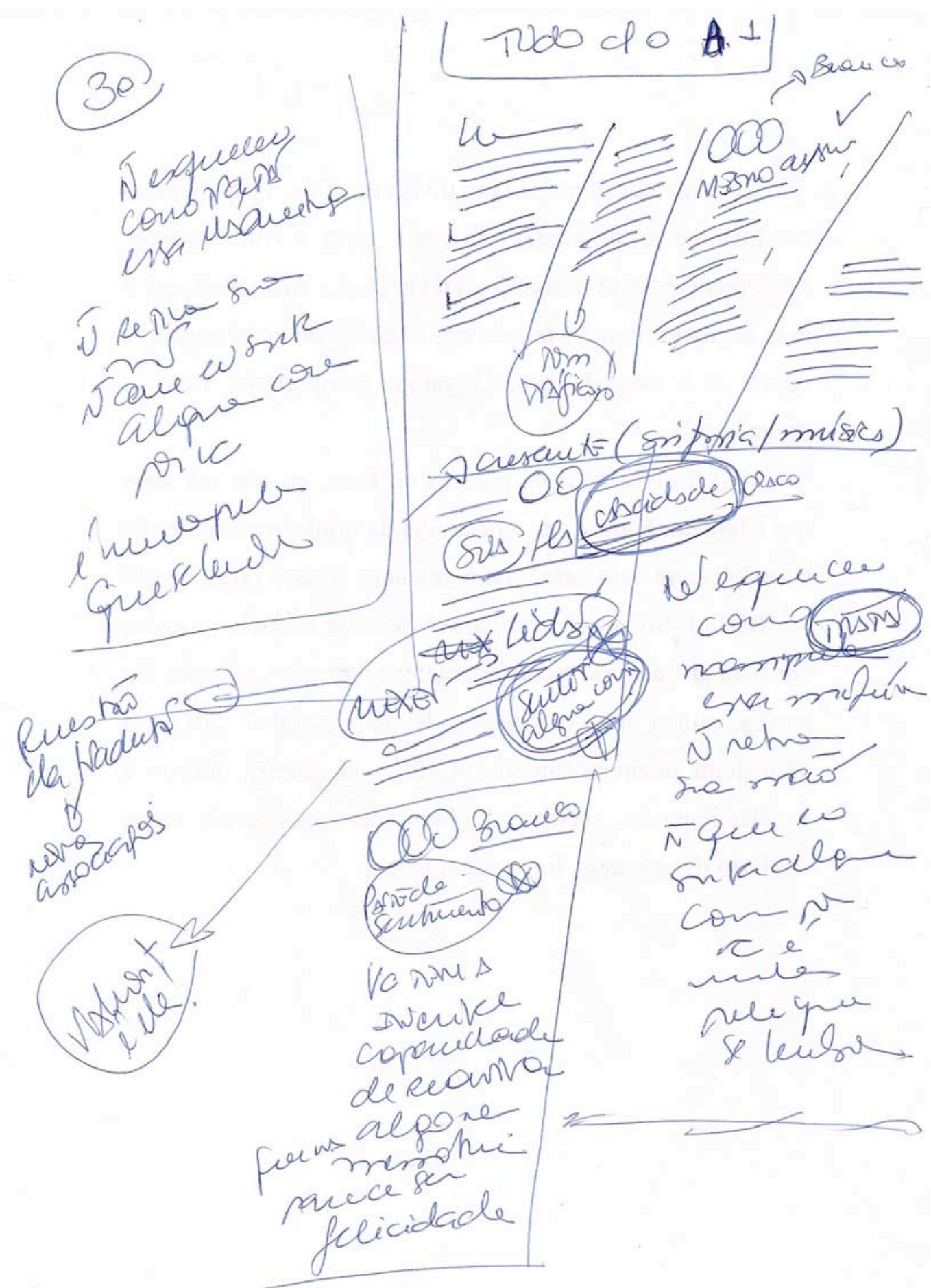

Exemplo 13:

Um tom grandiloqüente foi associado (junto a idéia de energia e sentimentos trágicos). $\mathrm{Na}$ cadência da imagem acústica "S (UAHHHH) $\underline{\mathrm{C}}(\mathrm{A}) \underline{\mathrm{P}}(\mathrm{A}) \underline{\mathrm{C}}$ (IDADE)", a repetição do "c" junto ao "p" associou "opaco". Na troca (correção) de "manipular" por "tratar", a partícula "mão" (de "manipular") associou a imagem de "uma mão que mexe". Errei novamente: troquei "mexer" por

"lidar". O erro associou "Valmont é Merteuil". Um esquecimento originou pausa. Neste momento, associações muito rápidas em busca da palavra correta. Os riscos indicam o rápido revezamento das imagens acústicas que se desenrolavam no pensamento. 


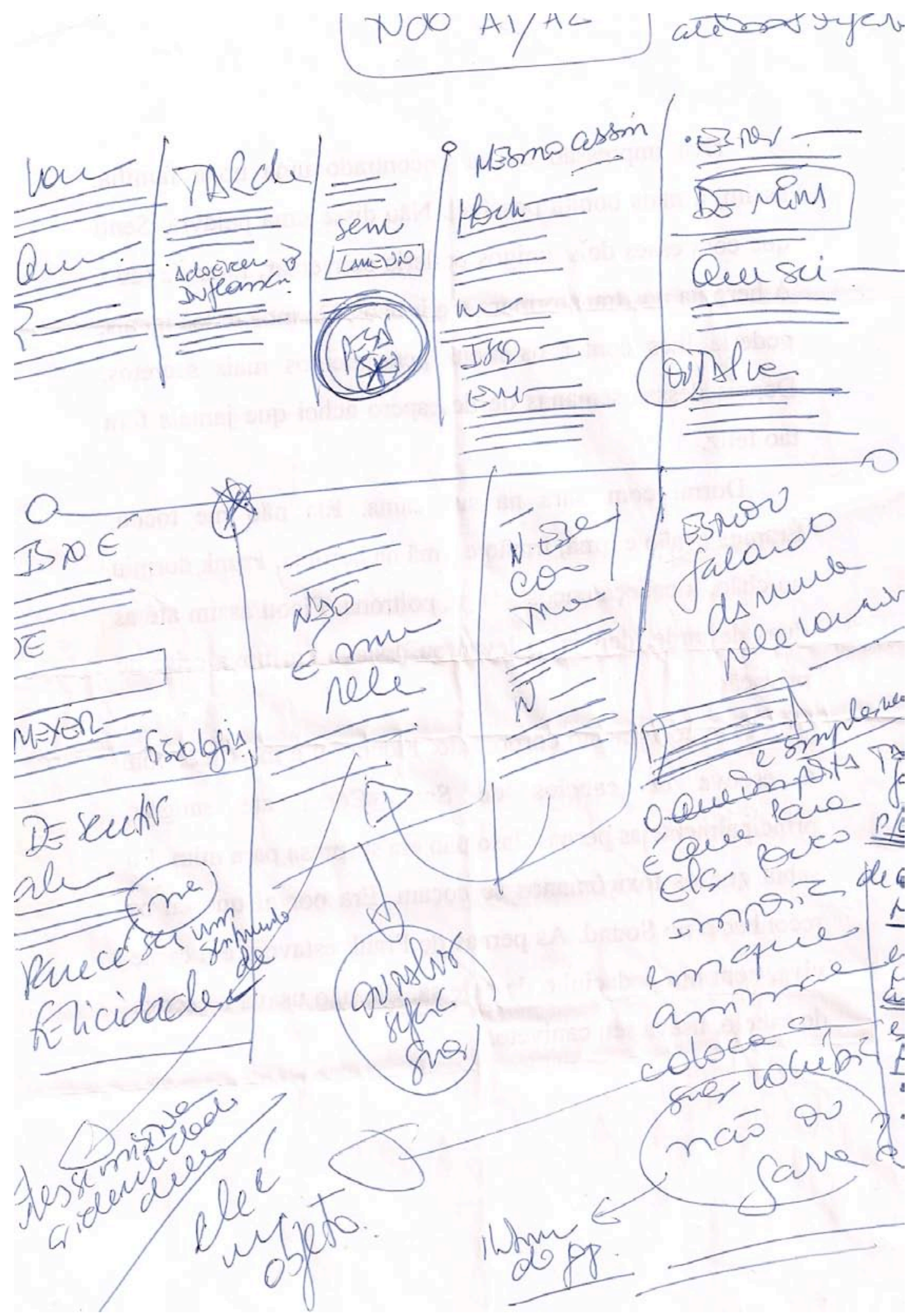

Exemplo 14:

Associações com "Valmont como objeto", "a mistura de identidades de um e outro", "mão ou garra como instrumento do jogo": imagens deixadas esquecidas. Em jogo de enunciação, a imagem "mão em garra" reapareceu integrada `a forma da partitura física que ajudava a transformar. 


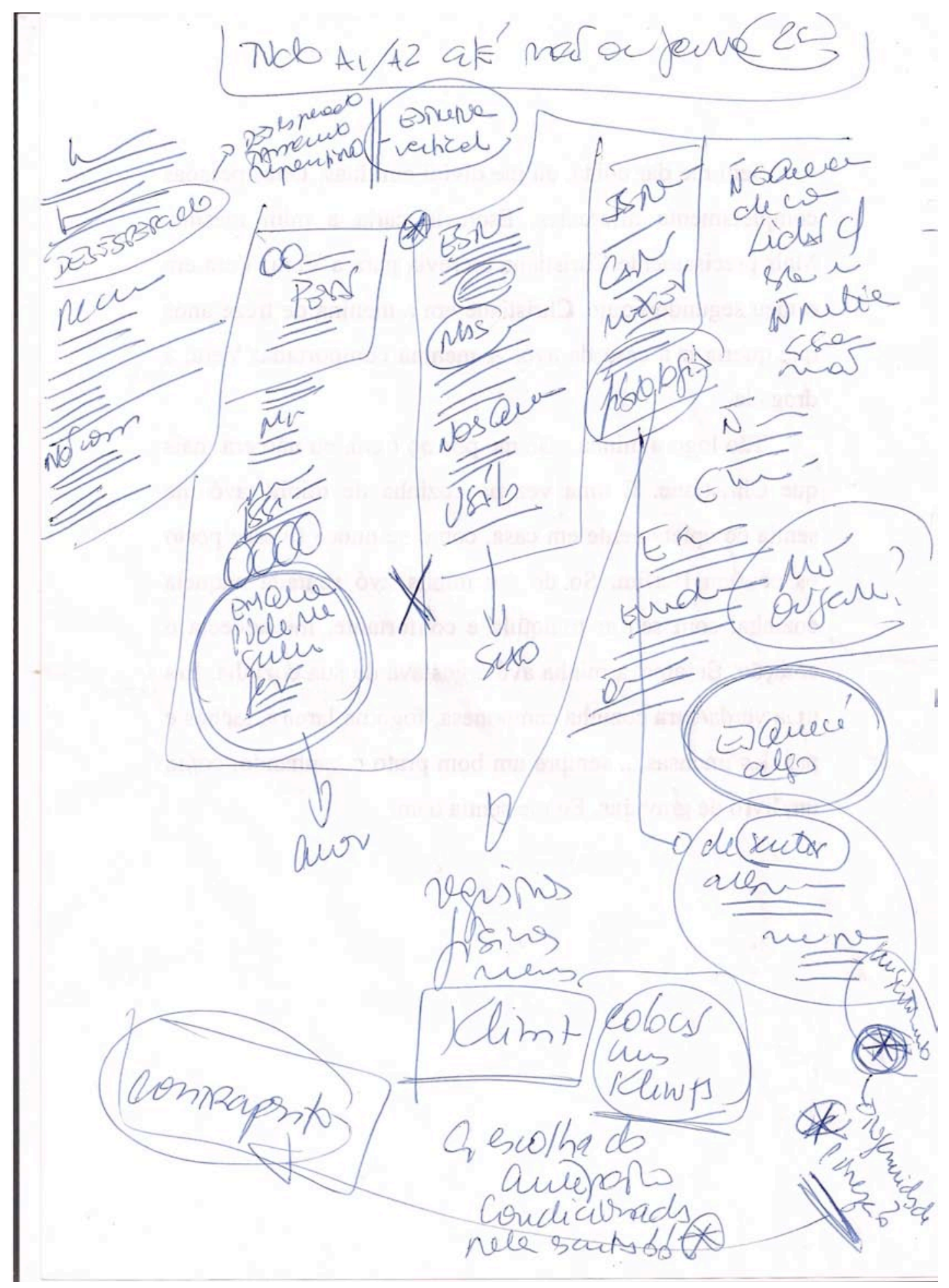

Exemplo 15:

Associação com figuras de August Klimt utilizadas em 1998, dez anos atrás, na prática com Jan Ferslev. Na época, estas imagens estavam associadas a certa qualidade física que a idéia "mão-garra" associava junto a imagem acústica "KKKKRRRRR". A palavra "sentimento" foi associada a idéias contrárias: "enfermidade" e "pureza". 


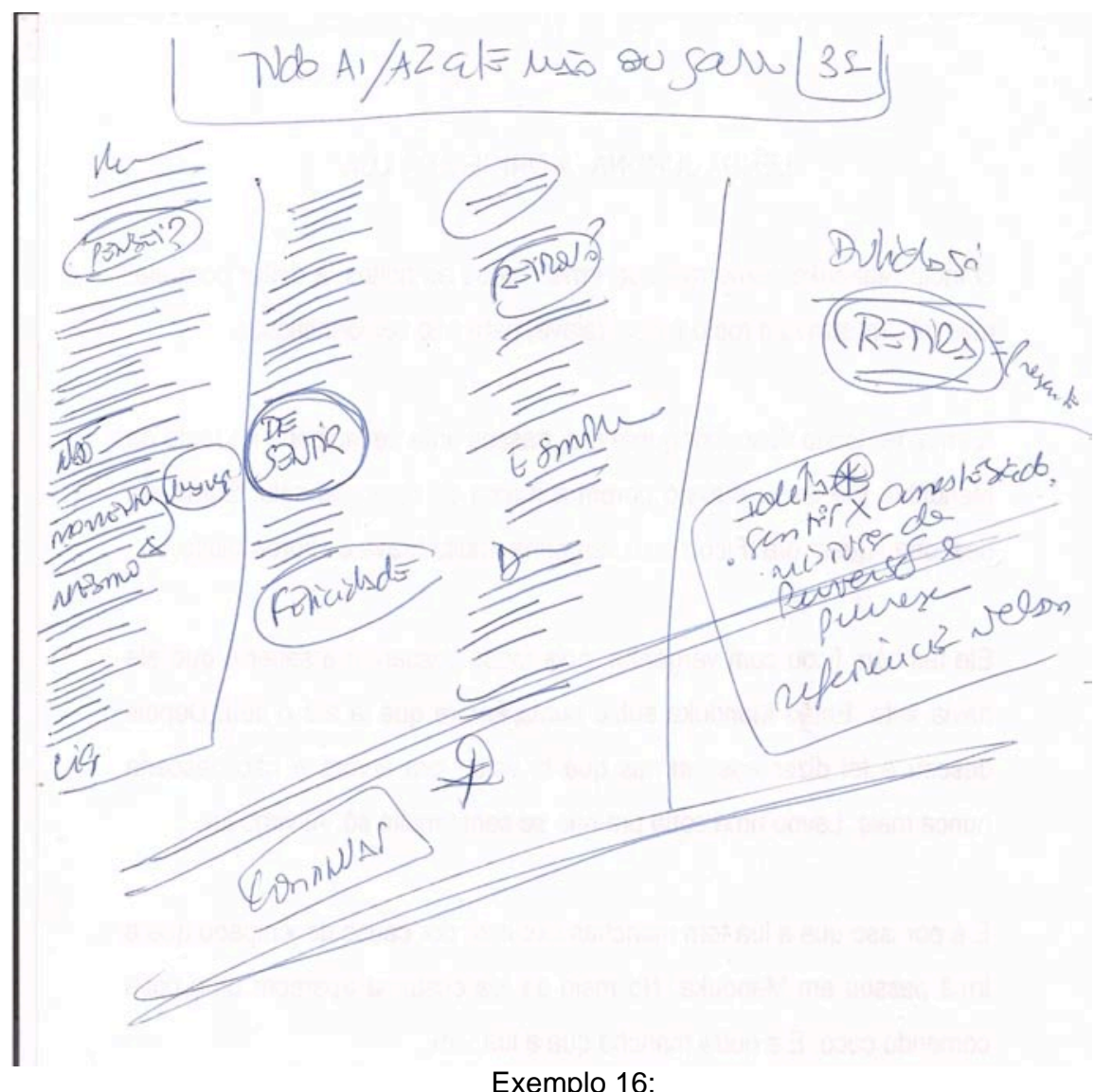

Idéias contrárias associadas juntas: "sentir e anestesia", "perversão e pureza".

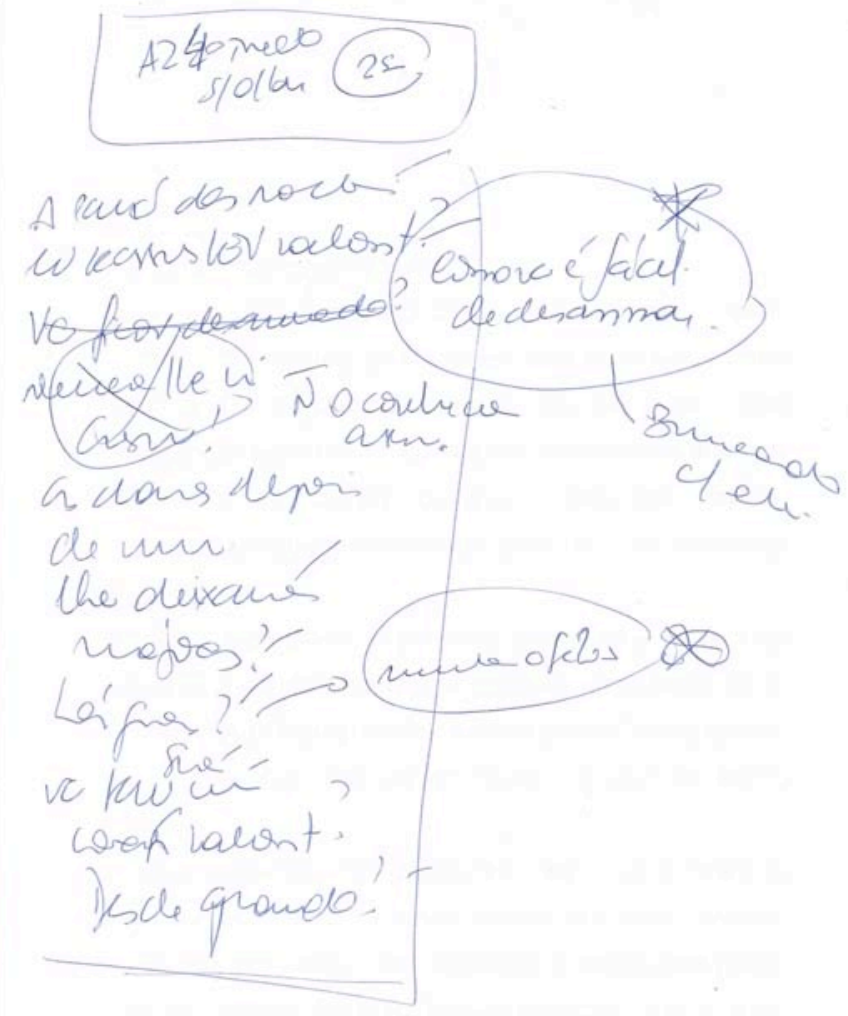

Exemplo 17:

A associação com uma ação: "brincar com ele, fazer troça". 


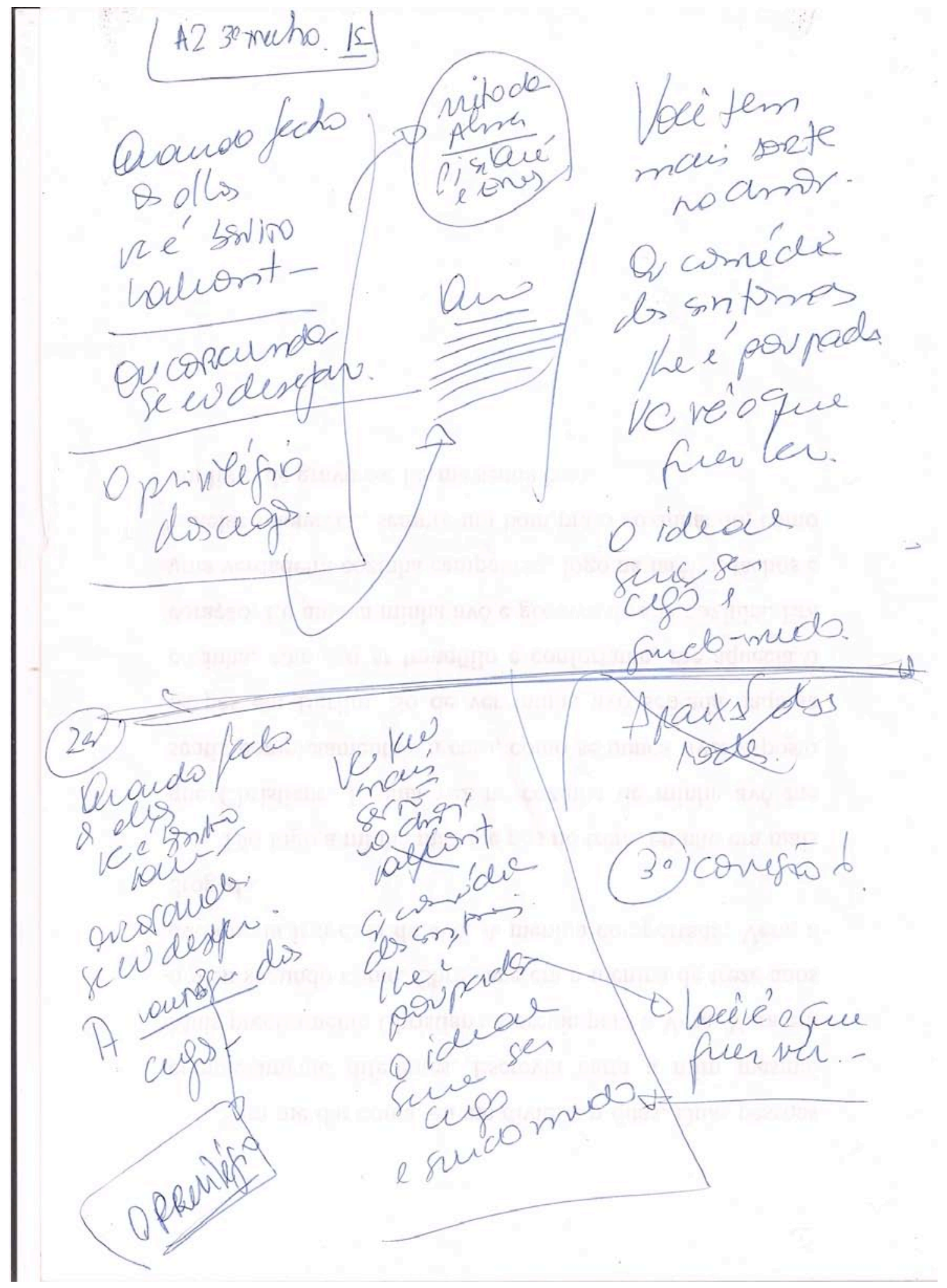

Exemplo 18:

Associação com um mito ("Eros e Psiqué") no momento em que escrevi "Quando fecho os olhos você é bonito Valmont". 
Se estou envolvida com o foco, as imagens "visualizadas" na posição do "instantâneo" se instalam "bem no corpo". A noção de idéia utilizada por Knébel favorece o sentido implicado.

La idea es un rayo. Durante días se acumula la electricidad sobre la tierra $Y$ cuando la atmósfera está carregada, los blancos cúmulos se conviertem en nubes terribles y armanazantes hasta que nace en ellas el rayo. Casi inmediatamente después viene el aguacero. La idea nasce en la conciencia del hombre cargada de pensamientos, sentimientos y recuerdos. Todo se acumula hasta alcanzar el grado de tensión y se produce una descarga: la idea. Pero para que surja la idea es necesario un mínimo impulso. Éste puede ser un encuentro ocasional, una palabra, un sueño, una voz lejana... (...) Si el rayo es la idea, entonces el aguacero es la manifestación de esa idea. Es una corriente de imágenes y palabras. Es un libro. (...) La cristalización de la idea, su esquecimiento, se dan constantemente, cada hora, cada día, siempre y en todas partes (...) (1)

A proposição retrata o que se passa durante o procedimento:

1. a idéia é descarga;

2. a idéia implica afeto;

3. é necessário um impulso inicial e este pode vir "de uma palavra";

4. a idéia articula-se a uma "corrente" de "imagens e palavras";

5. a idéia pode ser esquecida.

1. KNÉBEL, María, op. cit., pg 111. Knébel pede que os alunos busquem, na literatura, uma definição para o termo "idéia". Esta é uma citação do escritor russo (PAUSTOVSKI, Kostantin, Obras Completas, t.2, Judoszhestvenayz, pp. 521-522). 


\subsubsection{Libertar-se do Registro Escrito}

As imagens acústicas resultam encadeadas: uma leva a outra, que leva a outra, que leva a outra, a outra, a outra. Rápidas, desecadeiam, "desembestadas". Este "desenrolar" das imagens "no fio da memória" realiza, no corpo, a atividade de estar "sendo levado" em função de um foco. Sentese a dinâmica, o ritmo deste "levar": há acentos, sinuosidades, pausas, arrancadas, momentos fortes, fracos, há palavras propriamente marcadas e as que derrapam, escorregam (para chegar em outra, que ganha ênfase). Há uma dinâmica, um desenho. A velocidade da mão que escreve não acompanha este desenrolar. A caligrafia é completamente borrada.

Encontrei em Kusnet o momento em que uma atriz, escrevendo uma carta $\left({ }^{*}\right)$, borrou a caligrafia e registrou um traço. Kusnet a questionou: "'O que significa este traço longo que interrompe a frase no meio?' Significa: "não me desobedeça!', respondeu a atriz" (KUSNET, 1987: 126). "Não me desobedeça!": o engajamento no foco é perceptível. A imagem acústica concreta conduz o corpo. A atriz estava escrevendo com as próprias palavras. A Memorização Através da Escrita constrói o engajamento nas palavras já escritas, no texto do autor.

$\left.{ }^{*}\right)$ Uma carta era endereçada ao personagem do diálogo a ser encenado. A descrição deste procedimento está em KUSNET, Eugênio, Ator e Método, São Paulo: Hucitec, 1992, pg. 129-130. 


\subsubsection{Pensar o Texto}

As duas formas de ação, a física e a mental, são ligadas entre si tão intimamente que o ator dificilmente poderá estabelecer como e onde uma influi sobre a outra.

Kusnet

Não tenho mais o registro gráfico diante dos olhos. Há problema a resolver: como presentificar as imagens acústicas? Me "concentro". Coloco o "ponto do concentração" (outro termo de Viola Spolin para "foco") na imagem acústica: VAUMOUM (1 $\left.\begin{array}{lll}1 & 2 & 3\end{array}\right)$ EUDÁVA PURACABÁ DÉSSASUA PAI CHÃUMPURMIIIIIIIIIIIIINHHHHHHH?!!!!! Entro em jogo: o tônus aumenta, há vibração nas têmporas, no coro cabeludo, há "vontade de fala", pressão em torno dos olhos, respiração alterada, o coração acelerado. Acompanho a imagem acústica que se desenrola no pensamento, grossa e densa, e sinto o corpo passeando pelas percurssões, sinuosidades, voluptuosidades, derrapadas, correrias, o organismo "ao dispor" enquanto uma ação desponta. Ainda não sei o que é. Preciso dos jogos. As inúmeras associações desaparecem. Algo silencia.

1. A imaginação, inventa a si mesma, se abre para as possibilidades, libertando-se do ser e do dever para aceitar o desafio do poder ser; onde a consciência está à beira de muita coisa, sem saber bem o que, gerando imagens imateriais do mundo tal como este existe em sua aparência precária, fugidia e imediata, isenta de normas e coações; 2. a ação, quando o sujeito, ativamente pronto, sem tensão ou distração, penetra no tempo presente e viabiliza aquilo que sua imaginação pré-dispôs ligando-se assim ao processo cultural concreto; 3. a reflexão, que Ihe permite fazer a si mesmo uma proposta de continuidade de si próprio, de sua consciência e de sua ação, numa integração com o passado capaz de permitir-lhe o exercício teórico, isto é, a previsão do futuro, o círculo se fecha e a imaginação é de novo ativada.

1. COELHO, Teixeira. O Que é Ação Cultural, São Paulo: Brasiliense, 2001, pgs. 93-94. 


\section{Capítulo 2}

\section{Primeira Modalidade de Jogo}

Deveria ser considerado também o prazer de inventar; a tomada de consciência da espessura sensual de um momento fugaz. Jean-Pierre Ryngaert

O texto pode ser jogado de diferentes maneiras; cada um pode descobrir coisas que outros não perceberam, o que evidencia o aspecto plural que pode ter a leitura de um texto; seu sentido não é único, nem é dado de antemão. Maria Lucia Pupo

A lingua apresenta, pois, este caráter estranho e surpreendente de não oferecer entidades perceptíveis `a primeira vista, sem que se possa duvidar, entretanto, de que existam e que é seu jogo que a constitui.

Sausurre

El estudiante notó admirado que cuando tomaba el agua le vino a la mente una serie de pensamientos e imágenes. 


\subsection{A Transformação da Partitura}

Esta ação, que é a alma de todas as artes protegidas pelas Musas, pode perfeitamente receber o nome de jogo. Huizinga

Havia uma questão implicada na inscrição do texto no corpo. Era preciso construir o corpo. Estávamos trabalhando com a noção de ação física que "evoca" a ação. Era preciso construir a forma do corpo que "evoca a ação". Estávamos trabalhando com a noção de ação física que "não pode ser definida". Era preciso construir a forma que "resta ao nome da ação".

\begin{tabular}{|l|l|l|}
\hline \multicolumn{1}{|c|}{ AÇÃO FÍSICA } & \multicolumn{1}{|c|}{ AÇÃO } & \multicolumn{1}{c|}{ ATIVIDADE } \\
\hline A inscrição do corpo em & A parte da ação física & Inscrita no contexto do ator, \\
cena. Evoca ação e & que pode ser nomeada. & não evoca ação. Para \\
relação com o outro. É & Inscreve-se na fábula, & transformar-se em ação física \\
cênica e, enquanto & na ficção imaginada. & precisa ser integrada a outros \\
significante, singular. & & elementos. \\
\hline
\end{tabular}

Este pensamento me levou a jogar com inscrições físicas do corpo em atividades cênicas (a construção de "esquemas", formas de organizar o corpo no espaço, deslocamentos, composições, seqüências) e transformá-las (disfarçar sua aleatoriedade) para evocar a ação. Estes esquemas eram encadeamentos (fixos, partiturizados) de formas do corpo.

1. Para o Primeiro Monólogo de Merteuil, a mimesis de uma performance criada em exercício de apropriação de um outro texto implicava: torções do tronco, o movimento das mãos e 
braços, variações no ângulo da cabeça e costas. Chameia-a de Partitura de Mimesis de Performance.

2. Para o Reencontro entre Valmont e Merteuil mimetizamos imagens de filmes, atividades do cotidiano (observadas em pessoas na rua), "figuras" masculinas e "em dupla" (de imagens pictóricas) e "percursos no espaço" (desenhados em uma folha de papel).

3. Para o Segundo Monólogo de Merteuil, uma mimesis de Fred Mercury: as explosões de tônus, o jeito de andar, movimentos de bacia e boca, o ângulo da cabeça.

4. A Cena da Turvel foi trabalhada com o "jogo das partes do corpo": por sorteio unimos um percurso desenhado em uma folha de papel e uma determinada parte do corpo. A junção ao acaso produziu formas por sua vez associadas a frases do texto. As ações físicas resultantes foram partiturizadas.

5. A Cena da Volange foi trabalhada com uma partitura física de "imagens do corpo" vivenciando jogos tradicionais e teatrais (spolianos).

6. Para a última cena não trabalhamos partituras físicas, apenas momentos de esquecimento: as reações contextualizadas na ficção ("disfarçadas" como ações da personagem).

Escolhi exemplos que enfatizam o caráter instantâneo da inscrição de imagens que, "fora do foco" (esquecidas), voltam a se instalar "bem no corpo" disposto a resolver problemas em jogo. A diferença das posições na 
estrutura ("foco" e "espontâneo") é perceptível, bem como a posição da

"resultante", que o ator não domina $\left(^{*}\right)$. O foco é "disfarçar a aleatoriedade da forma, borrá-la” (a transformação das partitura físicas em ação física para a sua inscrição na ficção como ação): uma modalidade específica de jogo.

Qualidades físicas dividiram o foco (pequeno, grande, rápido, lento, pesado, oleoso, estacato) $\left.{ }^{(*}\right)$, bem como a enunciação de Quarteto. Como resultante, certos encadeamentos de ações pontuados por momentos de pura atividade pois nem tudo foi transformado. Depois da primeira modalidade de jogo, voltei `a escrita e me dediquei a leituras. O contato com "elementos externos" provocou associações com o que já estava em cena. Foi possível, então, ler a ficção a partir do encadeamento das resultantes.

\subsection{A Partitura de Mimesis de Performance}

\subsubsection{A Construção por Mimesis}

Construi a partitura mimetizando a resultante cênica de um jogo, criado em 2007, junto ao CEPECA, para a apropriação do texto Pretty Womam (do autor brasileiro contemporâneo Sergio Roveri). Neste jogo,

(*) "Uma outra teoria que apresenta relevantes traços filosóficos é do Jogo como modelo hermenêntico e metáfora do mundo. Seus principais representantes são Gadamer e Fink. $O$ autor de Verdade e Método (1960) desenvolve uma análise anti-subjetivista e anti-humanista, insistindo no fato de que o protagonista efetivo do jogo não é o jogador, mas o próprio Jogo que se produz por meio dos jogadores. Circunstância que estabelece uma espécie de "primado" do Jogo sobre os jogadores, de tal modo que jogar é, no fundo, ser jogado: "é mais o Jogo que joga, incluindo em si os jogadores e fazendo-se ele mesmo o autêntico subjectum do Jogo (trad. It., Bompiani, Milão, 1938, p. 558). A noção de Jogo serve a Gadamer para pensar as múltiplas determinações da arte (a começar pelo primado da obra em relação a seus autores e fruidores) e para caracterizar a essência da linguagem, que, na sua concreta execução, implica sempre um "arrebatamento" lúdico, em cujo âmbito deixa de ser determinante "a vontade do indivíduo" (ibid, p. 115)" (ABBAGNANO, Nicola. Dicionário de Filosofia, São Paulo: Martins Fontes, 2007, pg. 679).

$\left.{ }^{(*}\right)$ Em música, tocar "em estacato" é tocar "sem ligadura". 
nomeado "Jogo das Famílias das Palavrinhas": uma relação fixa entre a enunciação de certas palavras da síntaxe ("mas", "porque", "como", "eu", etc) e o repertório de ações físicas constituído de outros laboratórios. O encontro "ao acaso" e a integração dos elementos produziu resultantes: novas ações físicas. O workshop foi filmado. Mimetizei imagens, que foram partiturizadas para o jogo com o primeiro trecho de Quarteto: O Primeiro Monólogo de

\section{Merteuil.}

\begin{tabular}{|c|c|}
\hline & PARTITURIZAÇÃO DAS RESULTANTES DO JOGO COM "PRETTY WOMAM" \\
\hline 1. & A mão esquerda apoiada no banco e a direita no olho \\
\hline 2. & Fecha a mão como se cheirasse \\
\hline 3. & Pisca e balança a cabeça em um "não" \\
\hline 4. & Desmonta e olha pra frente \\
\hline 5. & Monta na diagonal \\
\hline 6. & Esqueda baixa \\
\hline 7. & Olhando para o braço esquerdo \\
\hline 8. & Acompanhando até a parte de cima \\
\hline 9. & Volta \\
\hline 10. & Vai em um movimento decidido para os seios \\
\hline 11. & Um espasminho \\
\hline 12. & Vira-se para a diagonal esquerda \\
\hline 13. & Apóia a mão esquerda no banco \\
\hline 14. & A direita apoiada no banco \\
\hline 15. & Em frente ao externo - a esquerda fechada \\
\hline 16. & Uma respiração - faz balançar, suavemente, o tronco \\
\hline 17. & Com agilidade, limpa os lábios \\
\hline 18. & Levanta a cabeça \\
\hline 19. & Respira mais forte \\
\hline 20. & Fecha os olhos e balança o tronco \\
\hline 21. & Num balanço lateral conserta a coluna \\
\hline
\end{tabular}




\begin{tabular}{|c|c|}
\hline 22. & Mais balanço e ocilação \\
\hline 23. & A mão esquerda sobre a perna \\
\hline 24. & Explosão e levanta o queixo \\
\hline 25. & Inspira \\
\hline 26. & Inclina a cabeça para o lado esquerdo \\
\hline 27. & Acentua o foco do olhar \\
\hline 28. & Balança a cabeça em uma negativa enfática \\
\hline 29. & Gesto da mão cortando o ar \\
\hline 30. & Abre a mão em uma pequena explosão \\
\hline 31. & Acompanha, com o olhar, o "escrito" (as palavrinhas estavam escritas) no braço \\
\hline 32. & Acompanha, com o olhar, descendo pelo braço esquerdo \\
\hline 33. & Em diagonal alta levanta a cabeça para frente \\
\hline 34. & O braço encolhe um pouco \\
\hline 35. & Estica com a mão apoiada no banco \\
\hline 36. & Joga a cabeça sobre o ombro esquerdo \\
\hline 37. & As costas esticadas \\
\hline 38. & Muda o ângulo da coluna \\
\hline 39. & Cai para trás \\
\hline 40. & A cabeça ainda mais para trás \\
\hline 41. & O olhar baixo \\
\hline
\end{tabular}

Partitura de Mimesis de Performance, resultante do jogo com Pretty Womam

\subsubsection{Qualidades Físicas em Foco}

No ano de 1998 tive a oportunidade de treinar a Dança dos Ventos, formalizada pela atriz do Odin Teatret Iben Nagel Rasmussen. A Dança dos Ventos consiste em saltar, revesando o apoio dos pés, utilizando a respiração, ocupando todo o espaço. No treino coordenado pela professora Elisabeth Lopes (na Universidade de São Paulo), dançávamos a Dança dos Ventos com qualidades físicas diversas: grande, pequeno, leve, pesado, anjo, 
demônio, etc. Dançávamos em grupo e, a cada troca de olhar, ações eram evocadas: um "encontro amistoso, um sorriso, uma aproximação" (com o "anjo"), "o ódio, o embate, a disputa" (com o "demônio"), a "delicadeza, o cuidado, carinho, desamparo, pedir ajuda" (com "pequeno"), etc.

Percebi que a qualidade física, quando em foco, "transformava a forma" inscrita em cena (uma atividade, contexto da atriz), de maneira que a ação "aparecia" (era "evocada"). Comecei o jogo com o Primeiro Monólogo de Merteuil integrando qualidades `a partitura física. Foram originadas ações nomeadas a posteriori: "sobressaltar-se", "enfeitar-se", "olhar ou não olhar", "esperar por Valmont". Uma relação com o outro se estabeleceu. No caso, este outro do universo ficcional: Valmont.

\begin{tabular}{|c|c|c|c|}
\hline SEQÜÊNCIA DA PARTITURA & FOCO DIVIDIDO & $\begin{array}{l}\text { AÇÃO FÍSICA } \\
\text { RESULTANTE }\end{array}$ & $\begin{array}{c}\text { AÇÃO } \\
\text { EVOCADA }\end{array}$ \\
\hline $\begin{array}{l}\text { Vai em um movimento decidido } \\
\text { para os seios, um espasminho, } \\
\text { vira-se para a diagonal esquerda, } \\
\text { apoia a mão esquerda no banco, a } \\
\text { direita apoiada no banco, em frente } \\
\text { ao externo a esquerda fechada, } \\
\text { uma respiração faz balançar } \\
\text { suavemente o tronco. }\end{array}$ & $\begin{array}{l}\text { Transformar a } \\
\text { partitura junto `a } \\
\text { qualidade física } \\
\text { "pequeno" }\end{array}$ & $\begin{array}{l}\text { Balancinho do corpo em } \\
\text { estacato ("tranquinhos"). } \\
\text { As mãos avaliam, } \\
\text { arrumam, checam, } \\
\text { consertam, protegem o } \\
\text { corpo. O queixo para } \\
\text { cima. }\end{array}$ & Recompor-se. \\
\hline $\begin{array}{l}\text { Inclina a cabeça para o lado } \\
\text { esquerdo, acentua o foco do olhar, } \\
\text { balança a cabeça em uma negativa } \\
\text { enfática, gesto da mão cortando o } \\
\text { ar, abre a mão em uma pequena } \\
\text { explosão. }\end{array}$ & $\begin{array}{l}\text { Transformar a } \\
\text { partitura junto a } \\
\text { "estacato" e } \\
\text { "grande" }\end{array}$ & $\begin{array}{l}\text { Forma de "empurrar o ar" } \\
\text { para a diagonal esquerda } \\
\text { baixa, revesando as } \\
\text { mãos com velocidade e } \\
\text { tônus alterados. }\end{array}$ & $\begin{array}{l}\text { Sobressaltar- } \\
\text { se, evitar olhar, } \\
\text { esconder-se. }\end{array}$ \\
\hline
\end{tabular}

Exemplo de transformação da Partitura de Mimesis de Performance 


\subsubsection{A Inscrição Espontânea de Imagens}

No momento de transformação da partitura (da "substituição" de uma forma por outra), imagens se instalaram, integradas `a ação física que ajudavam a construir. Já decantadas, porém esquecidas ("fora de foco"), se instalaram sem planejamento na posição do "instantâneo". As resultantes inscreveram impulso.

\section{Exemplo 1:}

A sentença era: "Valmont, eu dava por acabada a sua paixão por mim. Qual a origem deste repentino recrudescer. E com tanta força juvenil?". Durante a aplicação da Memorização Através da Escrita, cometi um erro: troquei "repentino" por "tamanho". Na etapa da correção, REPEINTHINU precisava ser encaixado na frase. Ao passar os olhos por Valmont (registro escrito) associei um "susto". A imagem manteve-se "esquecida" ("fora do foco"). Em jogo de enunciação, com a transformação da partitura em foco, surgiu a ação "sobressaltar-se" e a imagem vocal "ÃãHH!!!!! VAUMOUM!!!!! Ã̃̃̃̃HH!!!!". A resultante inscrevia, no corpo, a "repulsa", a "histeria". 


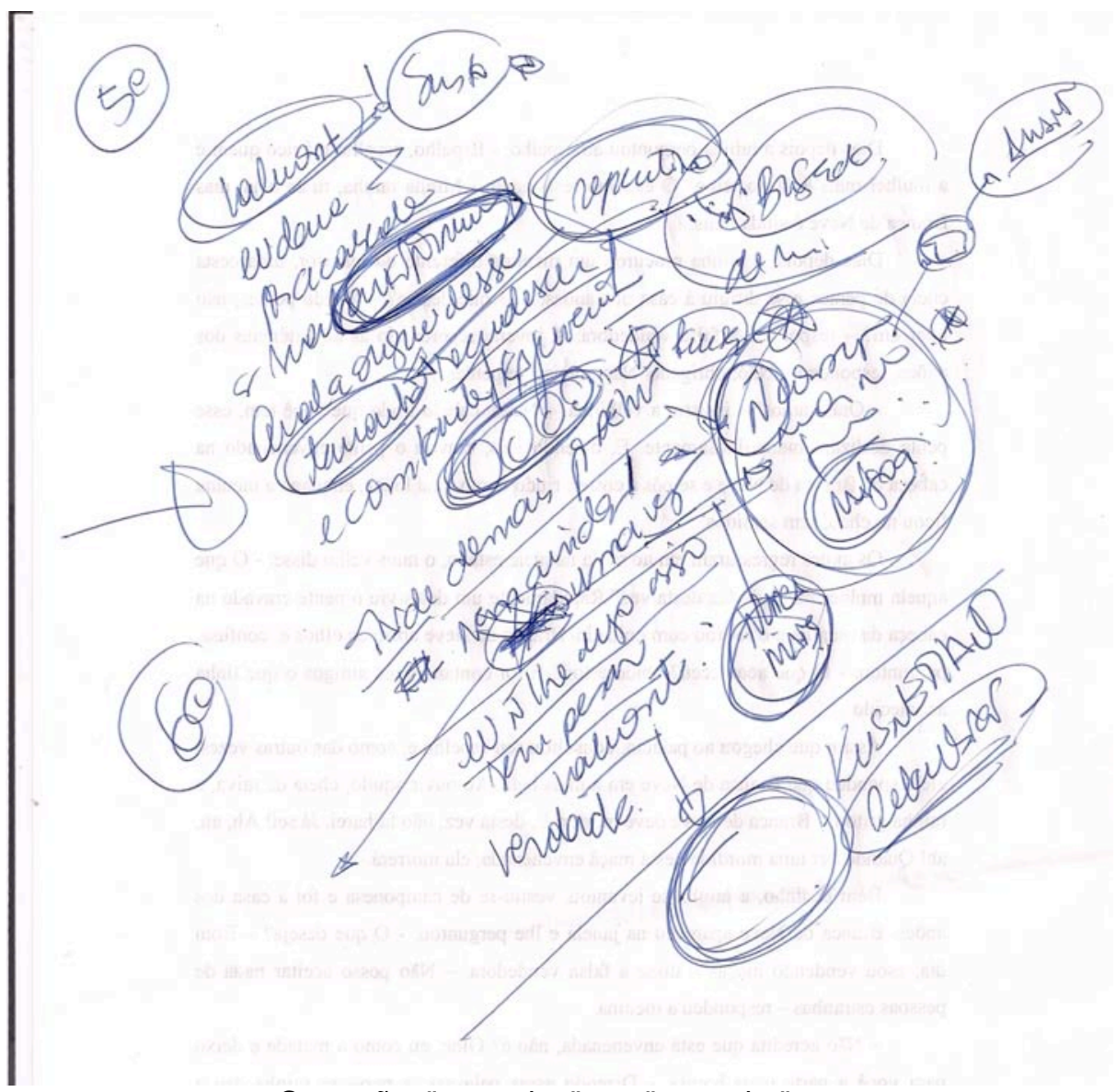

Correção: "repentino" por "tamanho".

\begin{tabular}{|l|l|l|l|l|}
\hline \multicolumn{1}{|c|}{ PARTITURA FÍSICA } & FOCO DIVIDIDO & \multicolumn{1}{|c|}{$\begin{array}{c}\text { AÇÃO FÍSICA } \\
\text { RESULTANTE }\end{array}$} & \multicolumn{1}{|c|}{ IMAÇÃO } \\
ESPONTÂNEA & EVOCADA \\
lado esquerdo, acentua o & partitura, & "empurrar o ar" & "susto" se & sobressaltar- \\
foco do olhar, balança a & enunciação do & para a diagonal & desenvolvou, & se, esconder- \\
cabeça em uma negativa & Primeiro & esquerda baixa, & combinando-se & se. \\
enfática, gesto da mão & Monólogo de & revesando as & com "Valmont & \\
cortando o ar, abre a mão & Merteuil e & mãos com & atrás do & \\
em uma pequena explosão. & qualidade & velocidade e & biombo nú". & \\
\hline
\end{tabular}

Primeiro retorno da imagem de "susto" na transformação da partitura com a enunciação 
O elemento foi presentificado também junto a outro jogo (Segunda Modalidade), em função do foco nas imagens acústicas "Idiota", "Que merda, que merda, que merda" e "Olha a hora" $\left(^{*}\right)$. Resultou integrado `a sentença do texto enunciado "Não conseguirá inflamar meu coração. Nem ainda mais uma vez!"

\begin{tabular}{|l|l|l|l|l|}
\hline \multicolumn{1}{|c|}{ EM FOCO } & \multicolumn{1}{|c|}{$\begin{array}{c}\text { AÇÃO FÍSICA } \\
\text { INSTANTÂNEA }\end{array}$} & IMAGEM & TEXTO-DADO & AÇÃO \\
\hline Sentença & Imediatamente de pé, o & Susto. & ENTRELAÇADO & EVOCADA \\
inventada & dedo em riste, olhando & & conseguirá inflamar meu & ponto final, \\
"Olha a & para o lugar onde ele, & & coração. Nem ainda mais & escapar de \\
hora!" & imaginariamente, se & & uma vez. Nunca mais. & Valmont. \\
& encontrava. & & & \\
\hline
\end{tabular}

Segundo retorno da imagem de susto na segunda modalidade com o Monólogo de Merteuil

\section{Exemplo 2:}

Durante a aplicação da Memorização Através da Escrita, a imagem de "um peso", um "corpo grosseiro", foi instalada durante a correção do registro gráfico (por ocasião do esquecimento da letra "O" que iniciava a sentença "O que sei eu de seus sentimentos"). A imagem não articulava contexto e foi deixada esquecida. Instalou-se no jogo com a qualidade "oleoso", junto a atividade "abrir os braços". A resultante evocou "cansaço", "enjoo", "tristeza".

$\left(^{\star}\right)$ A construção da subpartitura para a Segunda Modalidade de Jogo será descrita no capítulo 3. 


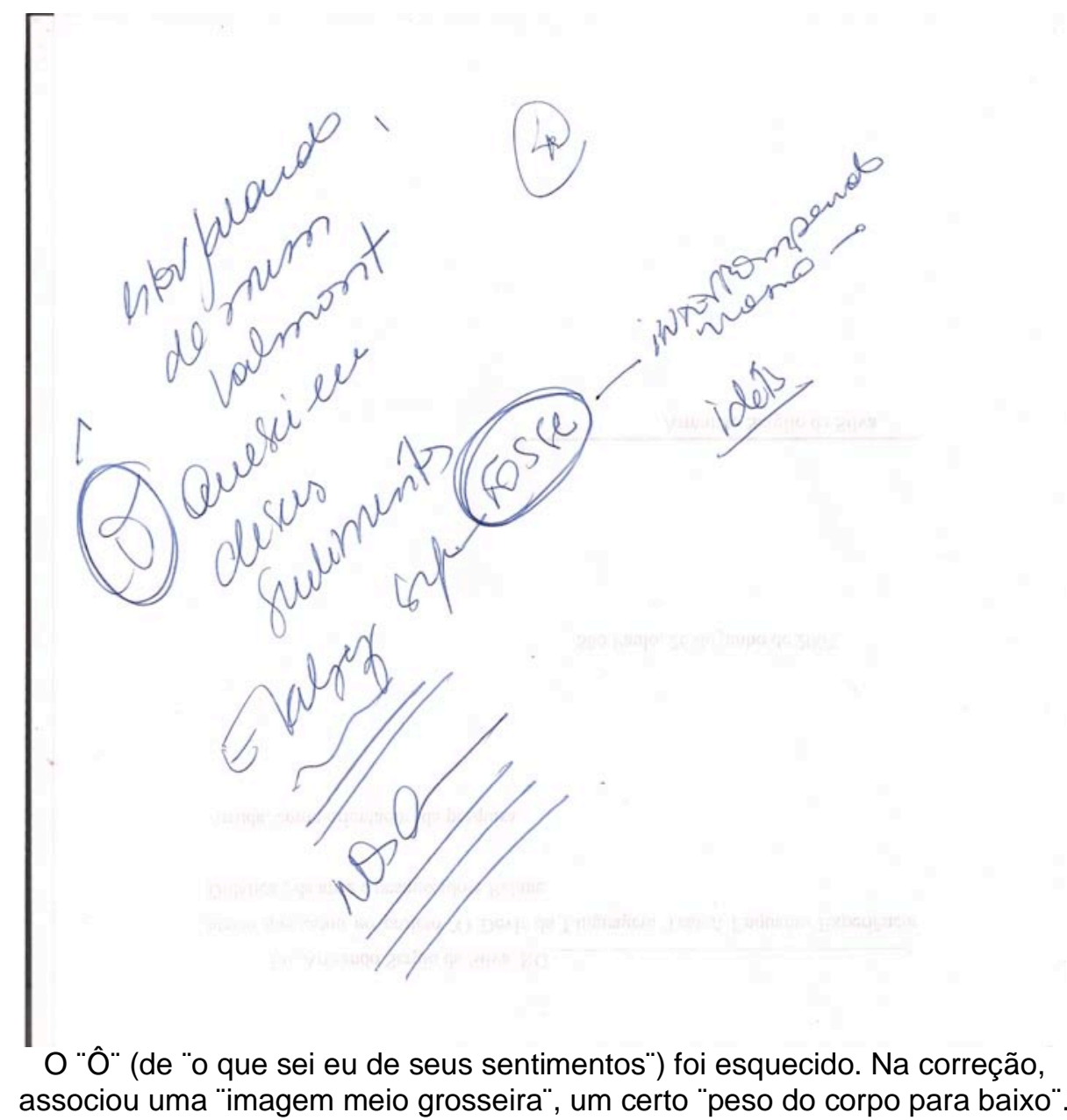

A mesma imagem foi presentificada na Segunda Modalidade de Jogo quando a regra "ocupar todo o espaço" entrou em foco. Caminhei para a direita e direcionei a fala para o lugar onde eu estava no instante anterior (a cada momento, o local deixado vazio se configurava como o "Valmont imaginário" para quem Merteuil direcionava as falas). A imagem se instalou, o "peso grosseiro". Se instalou em função da sentença da subpartitura "Perdão, eu também erreï. O mesmo elemento apareceu em outro momento (quando "ocupar todo o espaço" novamente situou o foco): em função da sentença "Tou bêbada". 


\begin{tabular}{|c|c|c|c|}
\hline FOCO DIVIDIDO & AÇÃO FÍSICA INSTANTÂNEA & IMAGEM INSTANTÂNEA & ENUNCIAÇÃO \\
\hline $\begin{array}{l}\text { Sentença } \\
\text { "Perdão, eu } \\
\text { também errei" e } \\
\text { "ocupar todo o } \\
\text { espaço". }\end{array}$ & $\begin{array}{l}\text { Caminhada lenta até virar-se } \\
\text { para o lugar que acabara de } \\
\text { ficar vazio ("Valmont"). }\end{array}$ & $\begin{array}{l}\text { Certo "peso do corpo } \\
\text { para baixo". }\end{array}$ & $\begin{array}{l}\text { Não Ihe digo isto sem } \\
\text { pesar Valmont. }\end{array}$ \\
\hline $\begin{array}{l}\text { Sentença } \\
\text { "Tô bêbada!" e } \\
\text { regra } \\
\text { "ocupar todo o } \\
\text { espaço". }\end{array}$ & $\begin{array}{l}\text { Desço da mesa com gestos } \\
\text { pesados, um pouco } \\
\text { desengonçada, e caminho em } \\
\text { torno de "Valmont", que está } \\
\text { sobre o praticável central. }\end{array}$ & (Idem). & $\begin{array}{l}\text { Eu te assustei, } \\
\text { Valmont? Como você } \\
\text { é fácil de desanimar. } \\
\text { Não o conhecia } \\
\text { assim. }\end{array}$ \\
\hline
\end{tabular}

A imagem de "certo peso do corpo para baixo" inscreveu-se no jogo de enunciação em função das sentenças da subpartitura: "Perdão, eu também errei!" e "Tô bêbada!"

\section{Exemplo 3:}

Há dez anos eu havia experimentado uma partitura de figuras (de August Klimt) junto ao contexto de Menina a Caminho (de Raduan Nassar), "uma praça" e o quem "prostituta". A integração deu origem a uma imagem do corpo com determinada posição das mãos, que evoca o erotismo, a agressividade (acompanhada por um som gutural). Durante a repetição do registro escrito da frase "Isto é, a sua capacidade de mecher com a minha fisiologia" (um pouco antes da expressão "mão ou garra") esta imagem foi presentificada (por associação "instantânea"). 


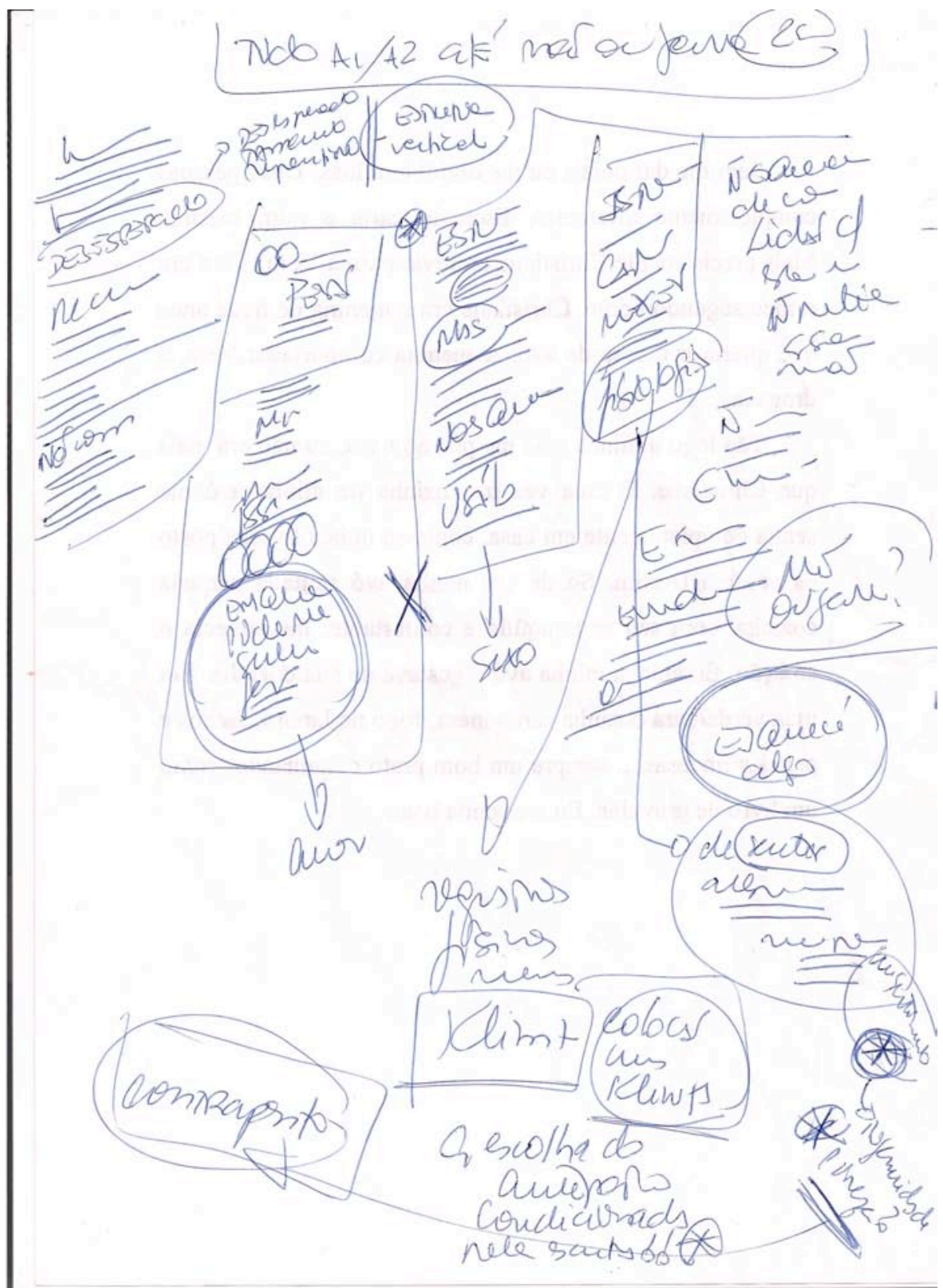

Associação com figuras de August Klimt: "enfermidade" e "pureza".

"Acompanha o escrito no braço, olhar subindo, acompanha o escrito no braço, olhar descendo e abre a mão em uma pequena explosão": era a atividade partiturizada. A "mão" assumiu tônus e forma "em garra". Experimentei um novo elemento em jogo: "olhar ou não para a platéia" (que já havia aparecido durante a escrita). Experimentei, também, uma "carta" nas mãos (a carta substituiu o "jornal" que havia aparecido durante a escrita). $\mathrm{O}$ registro "mão em garra" se inscreveu junto `a forma da partitura que ajudava 
a transformar e resultava na ação física "mostrar a carta para a platéia" (com tônus e agressividade implicados na "mão em garra"). O texto foi enunciado: "E simplesmente para ela tanto faz, de que forma ou em que animal está fixado o instrumento de sua volúpia, mão ou garra". No momento em que surgiu, a ação física inscreveu impulso.

$\mathrm{Na}$ Segunda Modalidade de Jogo (em função da subpartitura "Deixa eu sonhar") o corpo dançava ("seduzindo Valmont") com a imagem resultante do "jogo da Amarelinha" (*). Obedecendo a regra "ocupar todo o espaço", subi na mesa. Não estava com a carta. O tônus e a agressividade foram direcionados para o contorno do corpo, a pele, a roupa. Uma ação pontuou o movimento junto `a frase que foi enunciada com impulso: "E simplesmente para ela tanto faz, de que forma ou em que animal está fixada o instrumento de sua volúpia: mão ou garra".

\begin{tabular}{|l|l|l|l|}
\hline \multicolumn{1}{|c|}{ TEXTO ENUNCIADO } & \multicolumn{1}{|c|}{$\begin{array}{c}\text { AÇÃO FÍSICA } \\
\text { INSTANTÂNEA }\end{array}$} & IMAGEM & CONTEXTO DE ORIGEM \\
& \multicolumn{1}{|c|}{ INSTANTÂNEA } & DA IMAGEM \\
\hline E simplesmente para ela & Fazer alusão ao "rasgar & Forma da mão em & Treinamento Físico em \\
tanto faz, de que forma & a roupa". Com & garra, som gutural & 1998 com partituras de \\
ou em que animal está & agressividade, & KKKRRRRRRR. & figuras de Klimt junto ao \\
fixado o instrumento de & veemência, capricho, & quem "prostituta". \\
sua volúpia: mão ou & revolta. & & \\
garra. & & & \\
\hline
\end{tabular}

Inscrição instantânea da imagem no jogo com o Monólogo de Merteuil

$\overline{\left({ }^{\star}\right)}$ O trabalho com o "jogo da Amarelinha" será descrito ainda neste capítulo. 


\subsubsection{Imagem Vocal:}

A Memorização Através da Escrita nos coloca diante da imagem acústica. Ainda não é a voz.

O caráter psíquico de nossas imagens acústicas aparece claramente quando observamos nossa própria linguagem. Sem movermos os lábios nem a língua, podemos falar conosco ou recitar mentalmente um poema. (1)

Durante a escrita não há elementos pertinentes ao timbre, volume, ocilações entre grave e agudo. A "escuta" do texto é diferente da atividade de enunciá-lo (com a imagem vocal). A música da voz é um elemento relativamente autônomo (cuja melodia pode ser presentificada sem as palavras). Construída durante a atividade cênica inscreve cortes, ocilações, ritmo, dinâmica, acentos resultantes da integração entre partituras e imagens acústicas. A música da voz se fortalece com as repetições. É passível de ser cantada fora do jogo onde foi criada e sem as ações que a implicaram. É possível repeti-la na imobilidade. É possível utilizá-la "dentro ou fora do foco" (como elemento espontâneo que tende a voltar porque foi construído).

VÁU moum /.../ Eu DÁ va-pu-ra-ca bÁDÉs sassua pai chãummmpur mIIINHH

QuauÁ Ô rÍGEIN dessi RÊ penTHIno RÊcrudesCER / .../ Icum

TÂNtaFÔRçajuveNÍU??? / . ../ TARdjidjiMAISporÉINH / . ../

NÃO conseguiRÁ MAIZinflamARmeucoraçÃUM /.../

NEINHAINDAMAIZUMA VÊIZ / NÚNca /.../ mais /.../

/... / . . . ... NãolhedjiguĺssusseinhpesÁrvaumoum. ( $\left.{ }^{*}\right)$

1. SAUSURRE, Ferdinand, op. cit., pg. 80.

$\left(^{*}\right)$ Estou utilizando a transcrição fonética a título de exposição. 


\begin{tabular}{|c|c|c|}
\hline SENTENÇA & IMAGEM VOCAL & INSCRIÇÃO DE ELEMENTOS \\
\hline Valmont & $\begin{array}{l}\text { (Arranque) } \\
\text { VÁÁÁÁÁÁÁÁUMMOOO } \\
\text { OOUUMMMM!!!!!!!!!!!! }\end{array}$ & $\begin{array}{l}\text { O "susto" integrado aos movimentos da partitura } \\
\text { de mimesis de performance sustentou a } \\
\text { construção de uma "voz aflita, explosiva". }\end{array}$ \\
\hline & (Pausa) 123 & $\begin{array}{l}\text { A pausa é o tempo da reação frente ao eco da } \\
\text { voz no espaço. O tempo da percepção do que } \\
\text { acabou de acontecer ficou impresso na música } \\
\text { da voz. }\end{array}$ \\
\hline $\begin{array}{l}\text { Eu dava por acabada } \\
\text { essa sua paixão por } \\
\text { mim. }\end{array}$ & $\begin{array}{l}\text { (Novo arranque) } \\
\text { EUDAVAPURACABAAD } \\
\text { ESSASUAPAICHÃUMPU } \\
\text { RMINHHH!!!!! }\end{array}$ & $\begin{array}{l}\text { Saiu em um sopro só, em velocidade acelerada, } \\
\text { o corpo sustentado pela forma da partitura que } \\
\text { não estava estática, mas em transformação. }\end{array}$ \\
\hline $\begin{array}{l}\text { Qual a origem desse } \\
\text { repentino recrucescer } \\
\text { e com tanta força } \\
\text { juvenil? }\end{array}$ & $\begin{array}{l}\text { (Enunciação ritmada) } \\
\text { QUAUUUÁ (respiro) } \\
\text { O-RI-GEM (respiro) } \\
\text { DESSI RE-PEINTHINU } \\
\text { (respiro) } \\
\text { RE-CRUDESSSCER } \\
\text { (respiro) } \\
\text { ICUMTANTAFORÇAJUV } \\
\text { ENIIIUUU???? }\end{array}$ & $\begin{array}{l}\text { O "ORIGEM" ganhou acento, integrando o } \\
\text { ciúme, a raiva, a rivalidade (inscritos desde a } \\
\text { prática com a Memorização Através da Escrita), } \\
\text { que implicavam uma série de imagens: "eles } \\
\text { brigaram", "mágoa", etc. A repetição da sílaba } \\
\text { "RE" (já decantada enquanto imagem acústica) } \\
\text { gerou uma sucessão de acentos fortes, } \\
\text { integrados ao movimento de bater a mão na } \\
\text { perna (atividade física em cena). }\end{array}$ \\
\hline
\end{tabular}

Exemplos de elementos integrados `a imagem vocal nas primeiras sentenças de Quarteto

A diferença entre imagem acústica e vocal abre perspectivas para o jogo com diferentes "imagens" para a composição de uma imagem vocal. Os atores de Fundazione Pontedera Teatro, por exemplo, propõem uma estrutura rítmica (externa, autônoma) que se integra `a enunciação. Há certa liberdade para experimentar elementos na composição de uma partitura vocal quando a memorização é realizada pela escrita porque não há, ainda, um vínculo fixo com a intenção (e uma imagem autônoma pode entrar em foco). 
Em determinado trecho da Cena da Volange, a imagem "voz de cachorro" entrou em foco e a frase "Não é um pensamento edificante. Morrerei de tédio nessa sua figura triste" ajudou a transformar a partitura, evocando a ação "Valmont se finge de Merteuil assustando a menina". As imagens vocais resultantes de jogos com "voz de" resultaram firmes e bem desenhadas. Passaram a ser facilmente lembradas. A imagem de uma "reza" integrou-se `a sentença "(...) que não se cubra na rebelião contra minha virtude e feche o abismo de seus olhos, antes que nos devore", enunciada com uma oralidade típica dos cantos gregorianos. Evocou a ação "Valmont e Volange rezam juntos antes de começar o ritual da caça".

A imagem vocal é resultante do jogo (seja com a partitura física, com uma estrutura rítmica autônoma ou com imagens "voz de") e evoca ações. Depois de produzida a imagem vocal, a questão passa a ser situá-la ou não no foco. Na medida em que o ator precisa do texto para resolver problema, a imagem vocal o presentifica (pode se instalar espontaneamente, em função de outros focos).

\subsubsection{Absorção, Problematização}

A "absorção" da partitura tende a evocar ação quando há contexto implicado. "Absorção" é um termo utilizado para indicar a gradual diminuição do tamanho das formas. Com a absorção, a atividade interna é reforçada. $\mathrm{O}$ ator fica com os impulsos. No ano de 1998 construi uma partitura de atividades físicas com a professora Elisabeth (a partir do encadeamento de atividades de "lançar, empurrar e puxar"). Diminuído o tamanho da partitura, os impulsos podiam ser percebidos nos momentos de passagem de uma 
forma para outra. Extremamente absorvidas, as trocas evocavam as ações da "mulher de pescador que espera o barco chegar" (contexto em jogo): espasmos de ansiedade seguidos da desistência, a preocupação, o retorno `a espera, a atenção voltada para o mar.

Com o Primeiro Monólogo de Merteuil (na primeira modalidade de jogo), a partitura de mimesis de performance foi "absorvida" e a atividade carregada de tônus. Experimentei a imagem vocal em foco: a enunciação apoiada na dinâmica, nas variações do seu desenho. Em seguida, imagens resultantes do trabalho com outros fragmentos foram associadas e produzi uma nova imagem para o jogo: "Valmont como instrumento de vingança". $\mathrm{Na}$ época, estava lendo o que Müller dizia. Quarteto fora escrito depois da encenação de Mauser realizada por Christoph Nels em 1980. O encenador era de origem burguesa e utilizara um homem e uma mulher, "o único relacionamento violento que conheciam no âmbito de sua própria experiência de vida" (MÜLLER, 1997: 230): "Quarteto é um reflexo do terrorismo, com um tema, um material, que ‘a primeira vista nada tem a ver com o assunto” (idem: 230).

Falava sobre Fatzer-Material: "Matar com humildade é o núcleo teológico candente do terrorismo. Não existe solução para este paradoxo humano" (idem: 228): "O núcleo do problema é que o matar pode ser pensado. Se achamos necessário matar, não temos o direito de não fazê-lo nós mesmos: delegar seria imoral" (idem: 228). E ainda: "No andar de baixo morava minha mulher com outro homem, que estava violentamente apaixonado por ela" (idem: 231). 
Os assuntos se misturavam, as palavras associavam nossos corpos em cena (sua atividade, olhares, gestos, relações, ações já decantas, deslocamentos). As associações evocavam novas imagens: a tristeza de Valmont, a crise moral por não querer matar a menina Volange, o poder de Merteuil sobre ele (ela o obrigava a matar). O objetivo passou de "utilizar Valmont como instrumento de vingança" a "utilizar Valmont para matar". O Valmont encenado por Merteuil era o "seu", deliciosamente perverso. Já o Valmont do Reencontro entre Valmont e Merteuil era o "outro": questionava a libertinagem como profissão; tecia considerações sobre o vazio, o tempo, a morte; amava Turvel. Na Cena de Volange, este "outro" matava. Não era o "instrumento" do gozo físico, portanto, mas da "morte delegada".

Criei frases para a subpartitura (descritas no capítulo 3) sem que esta construção imaginária situasse o foco. Apenas me concentrei na sustentação "interna": o "tônus interno fortalecido" na absorção da partitura. Coloquei em jogo "fazer gestos grandes" e "ocupar o espaço". Um contexto apareceu como resultante do jogo com esta segunda modalidade. O corpo se deslocou, o olhar foi direcionado para cada lugar deixado vazio: Merteuil direcionava a fala para si mesma (o "seu" Valmont). Um encadeamento de ações físicas implicou a relação com "este" Valmont.

A construção imaginária "Valmont como instrumento para matar" não impediu outras inscrições no corpo. A imagem "mão em garra", por exemplo, evocava outras construções. "Deixa eu sonhar" (subpartitura) associava enleio e encantamento (e mesmo a "infantilidade“). O repertório foi inscrito em função da estrutura de regras e não da articulação imaginária, de 
maneira que o corpo se tornou o palco da integração entre "elementos relativamente autônomos".

A prática toca em considerações teóricas dicotômicas. Ubersfeld critica a construção ontológica da personagem. Propõe um lugar vazio na estrutura textual por onde o sentido passa, este que o espectador constrói "investindo" sua fala e desejo. Aqui, temos o ator, de certa forma, como espectador das resultantes, das inscrições espontâneas a partir da estrutura do jogo. A crítica de Ubersfeld é direcionada ao discurso que transforma a personagem em "uma" imagem petrificada.

Consideramos, então, que a noção de personagem (textualcênica), em sua relação com o texto e com a representação, é uma noção da qual uma semiologia do teatro não pode atualmente abster-se, mesmo que seja preciso considerá-la não como substância (pessoa, alma, caráter, indivíduo único), mas como lugar, lugar geométrico de estruturas diversas, como uma função de mediação. Longe de ver sob a personagem uma verdade que permite construir um discurso ou um metadiscurso organizado, é preciso, por certo, tomá-la como o ponto de convergência de funcionamentos relativamente independentes. (1)

A personagem (de teatro) não se confunde, portanto, com o discurso psicologizante ou mesmo psicanalizante que se pode construir sobre ela. Esse tipo de discurso, por mais brilhante que seja, nunca se mostra muito esclarecedor para o pessoal de teatro. (...) Enfim, há sempre o risco de ele fazer a personagem aparecer como uma "coisa" ou, quando muito, um ser a desvendar por meio de uma prática linguageira de desvelamento: há o risco de ele torná-la cristalizada, "petrificada", um objeto e não mais lugar indefinidamente renovável de uma produção de sentido. (2)

A dicotomia aparece quando a sistemática stanislavskiana propõe a construção da vida da personagem. No entanto, percebe-se que a criação de circunstâncias dadas era realizada a partir de fragmentos, de maneira a encontrar o que estimulasse 0 ator.

1. UBERSFELD, Anne. Para Ler o Teatro, São Paulo: Perspectiva, 2005, pg. 72. 2. UBERSFELD, Anne. op. cit., pg. 72. 
(...) desmembrá-la, examinar separadamente cada portão, rever todas as partes que não foram cuidadosamente estudadas, encontrar os estímulos ao fervor criativo, plantar, por assim dizer a semente no coração do ator. (1)

Eram criadas "numa base ad libitum (*), sob a forma de variações em torno da peça (...)" (STANISLAVSKI, 2005: 52) e cumpriam a função de concatenação: "Aceito-as não uma a uma, mas sim como parte indivisível de toda a complicada concatenação de circunstâncias da peça." (idem: 60). Reservatório de imagens para a inscrição espontânea, havia a necessidade de serem "esquecidas". Apesar do termo "foco" não ser utilizado, o jogo está devidamente implicado, quando não explícito.

Está bien, olvídense de la obra... aquí no hay nadie... No está ni Orgón, ni Mariana, no hay nadie. Sólo están ustedes, y ahora vamos a actuar. (...) El juego es así: nadie de los presentes puede cambiar de lugar hasta que no empiece a moverse el picaporte (...) (2).

Quando atingirem o momento da criação, não procurem o caminho do estímulo interior - seus sentimentos sabem mais o que devem fazer do que vocês lhes poderiam ensinar - mas atenham-se, antes, ’a entidade física do papel (3).

A produção subjacente implicava recombinações. "Seria erro fixar de uma vez por todas a avaliação dos fatos e acontecimentos de uma peça. A força desse estímulo está em sua novidade, em seu caráter inesperado" (STANISLAVSKI, 2005: 60); "Sua capacidade de aproveitar-se todo o tempo dessas mutáveis complexidades, seu poder de renovar seus estímulos por novas sendas, é parte importante da técnica interior do ator" (idem: 61).

1. STANISLAVSKI, Constantin. A Criação de Um Papel, Rio de Janeiro: Civilização Brasileira, 2005, pg. 29.

(*) Expressão latina que significa "'a vontade", "ao bel prazer".

2. S. Jimemez, El Evangelio de Stanislavski Segun sus Apostoles, México: Ed. Gaceta, 1990, pg 312.

3. C. Stanislavski, op. cit., pg 249. 
atividades passavam a evocar diferentes ações:

Uno de los ejemplos que pone Stanislavsky a este respecto tiene relación con su propia prática artística. Cuenta cómo interpretaba el papel de Argan en El enfermo imaginario, de Moliere. Al principio había definido su supertarea como "Quiero estar enfermo". A pesar de todos sus esfuerzos fue saliéndose de la obra. La divertida comedia de Moliere se fue convirtiendo en una tragedia. Todo esto provenía de una errónea definición de la supertarea. Por fin comprendió su error cuando descubrió otra definición, "quiero que me tomen por enfermo", todo encajó en su sitio. Inmediatamente se estableceron todas las relaciones con los médicos-charlatanes, enmediatamente resonó el talento cómico, satírico de Moliére. (1)

A construção subjacente é uma modalidade de subpartitura:

O efeito de verdade buscado por Stanislavski, a teatralidade buscada por Meyerhold, o efeito de estranhamento buscado por Brecht indicam objetivos opostos em termos de resultado, mas não divergentes no processo. Estes diferentes objetivos pressupõe, por trás da coerência da ação externa da partitura, uma coerente organização da subpartitura, de um "forro do pensamento" que o ator controla. Ela (a subpartitura) é constituída por imagens circunstanciadas ou por regras técnicas, por experiências ou perguntas feitas a si mesmo, ou por ritmos, modelos dinâmicos ou por situações vividas ou hipotéticas. (2)

Quando penso em Stanislavski encontro um homem que procurou extrair da prática princípios implicados na apropriação do texto dramático. Os que vieram depois mesmo não concordando com as premissas dialogaram com suas proposições. Stanislavski inaugurou uma discursividade a partir da qual foram desenvolvidos diferentes desdobramentos. Proponho um recorte da evidência do jogo e da escrita como procedimento. A escrita era utilizada não apenas para a memorização do texto mas na construção de um outro texto, criado pelo ator (além do esquema e detalhamento de ações físicas): "Se pueden descomponer nuestro cinco sentidos en una seria de

1. KNÉBEL, María, El Último Stanislavski. Madrid: Ed. Fundamentos, 2005, pg. 53.

2. BARBA, 1993: 171 upud BONFITTO, 2007: 80 
minúsculas acciones físicas y anotarlas en una hoja de papel" (JIMENEZ,

1990: 303).

(...) Agarrem-se `as palavras e frases isoladas de que tiverem necessidade. Escrevam-nas e acrescentem-nas a seus próprios textos livres. Quando chegarem `a segunda leitura e `as seguintes, tomem mais notas, recolham mais palavras para incluir no texto que vocês mesmos inventaram para seus papéis. Assim, gradualmente, com pedacinhos, e depois com frases completas, o papel passa a ser suprido com o texto exato da peça, de acordo com o estilo, a linguagem e a dicção da mesma (1).

A crítica de Ubersfeld torna-se pertinente quando nos deparamos com a necessidade de operar reduções para produzir imagens devidamente concretas. Ao tentarmos fundamentar a produção cênica na elaboração discursiva ficamos sem foco. Na Cena da Volange, por exemplo, Valmont lê uma carta para Merteuil. Não havia impulso. Foi apenas quando disse "Zé use isso: Olhe a carta que eu escreví", que a imagem acústica situou o foco e o corpo se disponibilizou, passando a evocar os elementos que faltavam. $\mathrm{O}$ que está em questão é como produzir elementos capazes de se intrometer em foco e situar o corpo com pulsão. Se não é possível colocar o "discurso" em foco, é possível transformá-lo em "detalhe", "elemento". Kusnet apontava para a necessidade da redução: "O ator reduzirá sua visualização a detalhes mínimos, aos mais condensados, mais excitantes" (KUSNET, 1982: 49). Toda elaboração verbal utilizada como procedimento passava por reduções:

A "carta" também passa pelo processo de condensação através das repetições nos ensaios, exatamente como acontece com a "visualização" e o "monólogo interior". (...) Com o correr dos ensaios eles se sintetizam, transformando-se finalmente em visões concentradas ao máximo, em símbolos ou exclamações em vez de frases completas. (2)

1. STANISLAVSKI, Constantin, op. cit., pg. 297.

2. KUSNET, Eugenio, op. cit., pg. 127. 
A cultura teatral abre perspectivas quanto a elaboração de uma subpartitura: perguntas feitas a si mesmo, regras, elementos da relação do ator com a obra. Esta abertura implica uma diversidade de modalidades. $\mathrm{O}$ que está em questão é, fudamentalmente, o que é capaz de "mobilizar" (e que implica questões éticas e estéticas) internamente: "Qualquer que seja a estética da encenação deve existir uma relação entre a partitura e a subpartitura, os pontos de apoio, a mobilização interna do ator" (BARBA, 1993: 171 upud BONFITTO, 2007: 80). Kusnet propunha a escrita da carta momentos antes do ator entrar em cena: uma imagem o estimulava a agir.

(...) enquanto escreve, fixa materialmente seus pensamentos, podendo, em seguida, racionalizar e selecionar os resultados obtidos espontaneamente. O resultado final desse processo geralmente é uma ação clara e (embora freqüentemente muito complexa) desprovida de toda confusão da invencionice psicológica (1).

Em certo momento do processo com Quarteto criei a sentença: "Eu quero que eles percam a fala" (como a última imagem, a última instância registrada pela escrita antes de ir ao jogo). Em outro momento, depois de realizarmos jogos com as partituras físicas, voltei a escrever. Escutando e vendo o encadeamento fixo de imagens já inscritas em cena, vivenciando "na imobilidade" estas atividades, uma ação surgiu de supetão: "usar o discurso religioso para caçoar de Turvel" (propulsora de impulso).

Devido `a organicidade dessa forma $\left({ }^{*}\right)$, 0 ator consegue mais facilmente adquirir a "fé cênica" na realidade da ação que se lhe propõe, ou em outras palavras ele chega mais facilmente a elaborar uma "instalação". (2)

1. KUSNET, Eugenio, op. cit., pg. 127.

$\left({ }^{*}\right)$ O autor está falando da escrita.

2. KUSNET, Eugenio, op. cit, pg. 120. 




Desestruturação da escrita de fragmento de texto da "Cena da Turvel"

A questão seria encontrar um caminho próprio para a elaboração, não só da partitura cênica, mas da subpartitura? Kusnet operava a lógica para criar objetivos "com máxima clareza, tornando-o por assim dizer palpáveis" (KUSNET, 1992: 33): "Diga: 'Eu quero vingar a minha honra"* (idem: 33). São "elementos", "fragmentos", que entram em jogo, e não uma imagem consistente "da personagem" a ser representada.

Vocês compreenderam? Esse 'Otelo' produzido pela sua imaginação, ou seja, visualizado por ele, vivia completamente `a parte, e ele, o aluno (...) resolveu simplesmente macaquear o seu comportamento. (1)

Kusnet opõe "representar" a "viver", "agir", "vibrar" (").

1. KUSNET, Eugenio, op. cit., pg. 41.

(*) "Representar" assume sentidos diversos. Por exemplo, Spolin o opõe a "jogar": "(...) fazer coisas fora de hora, 'representar', assumir 'personagens", e 'emocionar-se' ao invés de envolver-se com o problema imediato" (SPOLIN, 1979: 21). Já Luis Otávio Burnier o opõe `a "interpretar": mobilizar materiais próprios para a criação em oposição ao "ser o interprete" do texto (ver em FERRACINI, Renato. A Arte de não Interpretar como Poesia Corpórea do Ator. Campinas: Unicamp, 2003). Pode ser tomado como o ofício do ator: "A palavra "ator" que nos dicionários consta como significando 'agente do ato, o que age', é usada em quase todas as línguas como sendo "homem que representa em teatro" (KUSNET, 1987: 13). Pavis destaca o sentido de representação como "tornar presente": "Representar é também tornar presente no instante da apresentação cênica o que já existia outrora num texto ou numa tradição teatral" (PAVIS, 2008: 338). "Tornar temporal e auditivamente presente o que não o estava; apelar no tempo de enunciação para mostrar algo, ou seja, insistir na dimensão temporal do teatro. A representação não é, portanto, ou não exclusivamente, o espetáculo; é tornar presente a ausência, apresentá-la novamente 'a nossa memória, aos nossos ouvidos, ‘a nossa temporalidade (e não somente aos olhos)" (PAVIS, 2008: 340). 
Hoje o "traço" surge espontaneamente e se traduz em pensamentos (monólogo interior); amanhã, não se sabe porquê, ele conserva apenas seu aspecto material, um traço morto que não produz efeito algum, e o ator não age em cena, ele representa". (1)

Uns dirão que o bom ator "vibra" e o mau "fica frio"; mais outros dirão que o bom ator "vive o papel" e, com isso, chega a nos fazer acreditar na realidade da existência da personagem, ao passo que o mau ator "representa". (2)

Neste sentido, se jogamos com "Volange é uma putinha", o que se configura é um quem spoliano. A construção está articulada ao desejo de vingança e `a idéia de que Merteuil só consegue ser tocada quando é Volange. As imagens que desenham a ficção só entram em jogo quando reduzidas a elementos concretos. A construção parte do que Kusnet chama "primeira instalação": o contexto do ator.

O prazer de criação do ator significaria hoje o resultado da Primeira Instalação que forma uma espécie de fundo sobre o qual o ator projeta o resultado da Segunda Instalação - os sofrimentos do personagem.(3)

Há um campo de jogo com a subpartitura. "Tudo aquilo que o ator estabelece como pensamento da personagem antes, depois e durante as falas do texto" (idem: 71) é uma modalidade. Duas elaborações verbais: a do autor e a do ator. Lembra o jogo spoliano de manter "duas conversações ao mesmo tempo" $\left({ }^{*}\right)$ e o exercício proposto por Knébel onde 0 ator "pensa em uma coisa e fala outra" (**). A sistemática clássica investe na "materialidade" do pensamento: "Su pensiamento es siempre activo y concreto" (KNÉBEL, 2002: 63), "El estudiante necesita aprender a actuar pensando" (idem: 63).

1. KUSNET, Eugenio, op. cit., pg. 27. O grifo é do autor.

2. KUSNET, Eugenio, op. cit., pg. 5.

3. KUSNET, Eugenio, op. cit., pg. 56.

(*) SPOLIN, Viola. O Fichário de Viola Spolin, São Paulo: Perspectiva, 2000, jogo A 91.

$\left({ }^{* *}\right)$ Ver em KNÉBEL, María. La Poética de la Pedagogía Teatral, México: Siglo XXI, pg.46. 


\subsection{Deslocamentos no Espaço}

O trabalho com o Primeiro Monólogo implicara, até então, a imobilidade. Para trabalhar com o contraste, criamos partituras físicas que inscreviam trocas de lugar e deslocamentos. "Percursos" desenhados ao acaso em uma folha de papel e imagens de filmes foram partiturizados para 0 Reencontro entre Valmont e Merteuil.

\subsubsection{Percursos Desenhados na Folha de Papel}

Os percursos foram partiturizados. O texto enunciado se integrou `a seqüência de percursos. Alguns exemplos demonstram esta integração. $O$ percurso 1 evocou uma reação de Merteuil diante da revelação do nome da mulher por quem Valmont estava apaixonado: "Turvel". A sinuosidade gratuita e a distância considerável a percorrer foram "disfarçadas" na ação da personagem: "abalada, Merteuil se afasta". 


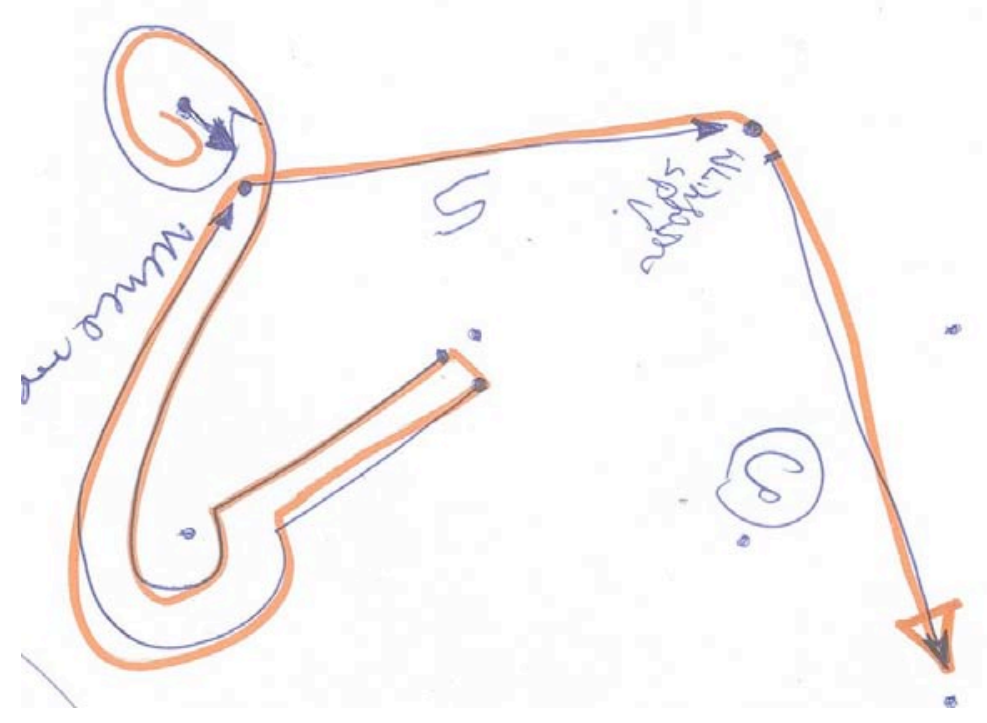

(Percurso 2)

A fala de Merteuil "Eu lhe entenderia se estivesses apaixonado pela pequena Volange, fresquinha, verdurinha da horta do convento, minha donzela sobrinha" acomodou-se na primeira curva do percurso 2 (na esquerda baixa). Os diminutivos ganharam ênfase com o acento nos agudos e o encadeamento ritmado das consoantes junto ao movimento circular da bacia, que contava com "pequenas sacudidelas".

\footnotetext{
"EulheenTenDeRiaseesTiVesseSapaixoNadoPelaPeQuenavoLange $|\ldots| \ldots \mid$

VEREuRiiiilNHA / FRESquiiiiNHAdaHORTaDoConVEnTo / MlnhaDonZElaSoBRiiiiiNnha".
}

A fala "Mas a Turvel!" integrou-se `a abrupta "virada" do corpo da segunda curva (na esquerda alta). A ação física resultante evocou "raiva, indignação": "Merteuil foi pega de surpresa, não esperava por esta, qualquer uma menos Turvel". 


\subsubsection{Imagens de Filmes}

Mimetizamos imagens do filme Orgulho e Preconceito (Pride \& Prejudice, baseado no romance de Jane Austen e dirigido por Joe Wright, que se passa na Inglaterra no final do século XVIII) cujo encadeamento nos serviu de partitura física. O encadeamento das imagens foi integrado a outros elementos, como qualidades físicas e a música Dor de Cotovelo (na interpretação de Elza Soares).

A seqüência de movimentos foi inscrita no contexto ficcional. "Encontro entre Valmont e Merteuil": Valmont a olha, a cumprimenta e the entrega um presente para, em seguida, afastar-se. $O$ que no contexto do filme correspondia a um livro (entregue `a protagonista), no contexto ficcional que criamos foi definido como "as cartas trocadas entre eles" (que, por sua vez, inspirariam as situações encenadas com os papéis trocados).

\begin{tabular}{|c|}
\hline PARTITURA DE IMAGENS DE FILME \\
\hline $\begin{array}{l}\text { Parar diante de uma paisagem linda, a câmera se afastando em pan; } \\
\text { Descer a escada rapidamente, com um livro na mão; } \\
\text { Dar um passo em direção ao homem que cuida do jardim. }\end{array}$ \\
\hline ENCADEAMENTO DE AÇÕES RESULTANTE DO JOGO \\
\hline $\begin{array}{l}\text { (Valmont e Merteuil se olham. Se analisam) "Valmont! Chegou bem na hora”. (Se cumprimentam) "E } \\
\text { quase lamento sua pontualidade. Ela reduz uma felicidade (...)" (Ele lhe entrega um presente. Ela } \\
\text { recebe. Se afasta) "(...) que, com prazer, teria dividido com você (...)" (Ele se afasta. Eles se olham de } \\
\text { longe) "(...) não se baseasse ela precisamente na sua capacidade de dividir, se é que entende o que } \\
\text { quero dizer". }\end{array}$ \\
\hline
\end{tabular}


$\mathrm{Na}$ Segunda Modalidade de Jogo, a mesma ação física que evocara "cumprimentar Valmont" evocou, por ocasião de outras associações, outra ação: "mostrar-se submissa". Evidencia-se a diferença entre a forma inscrita em cena e o elemento imaginário que ela evoca com os outros termos do encadeamento com os quais estabelece relação. A mesma inscrição física é "cumprimentar Valmont" em uma cena e "mostrar-se submissa" em outra.

\begin{tabular}{|l|l|l|l|}
\hline \multicolumn{1}{|c|}{ FOCO } & \multicolumn{1}{|c|}{ AÇÃO FÍSICA } & TEXTO-DADO & AÇÃO IMPLICADA \\
\hline Subpartitura & Subo no praticável central & Não retire sua tenra oferta, meu & Demonstrar \\
"Pera aí!" & onde ele se encontra e o & amado senhor, eu cumpro. De & submissão. \\
& cumprimento. & qualquer modo eu cumpro. & \\
& & & \\
\hline
\end{tabular}

Inscrição espontânea da ação física originada da partitura de imagens de filmes.

\subsection{Jogos de Regras}

\subsubsection{Jogo Tradicional}

\begin{tabular}{|c|c|c|c|}
\hline PARTITURA & ATIVIDADE & IMAGEM ACÚSTICA & AÇÃO \\
\hline Cinco Marias & $\begin{array}{l}\text { O jogador sentado. Cinco } \\
\text { pedrinhas. Ao lançar uma no ar, } \\
\text { pega, uma a uma, as que } \\
\text { ficaram no chão. O grau de } \\
\text { dificuldade vai aumentando. }\end{array}$ & $\begin{array}{l}\text { (VALMONT) Sim, eu } \\
\text { queria poder trocá-lo, este } \\
\text { meu sexo, aqui na sombra } \\
\text { do perigo de me perder } \\
\text { todo na sua beleza. }\end{array}$ & $\begin{array}{l}\text { Volange senta-se } \\
\text { no chão. Valmont } \\
\text { a acompanha. } \\
\text { Quase tocam as } \\
\text { mãos. }\end{array}$ \\
\hline Samurai & $\begin{array}{l}\text { Um jogador vendado, no centro } \\
\text { da roda, com um bastão } \\
\text { imaginário. Os outros fazem } \\
\text { barulho (com as mãos). Ele se } \\
\text { guia pelos sons e tenta atingi- } \\
\text { los com o bastão imaginário. }\end{array}$ & $\begin{array}{l}\text { Deve ser a vontade de } \\
\text { Deus, não? Senão, por } \\
\text { que esta arma de rosto? } \\
\text { Quem cria quer a } \\
\text { destruição. E não antes } \\
\text { que a carne apodreça, a } \\
\text { alma tem saída. }\end{array}$ & $\begin{array}{l}\text { Valmont a venda } \\
\text { e brinca de } \\
\text { localizar-se pelo } \\
\text { som da sua voz. } \\
\text { Longe, fala alto. } \\
\text { Perto, quase em } \\
\text { seu ouvido. }\end{array}$ \\
\hline
\end{tabular}




\begin{tabular}{|c|c|c|c|}
\hline Amarelinha & $\begin{array}{l}\text { Quadrados desenhados no } \\
\text { chão. O jogador lança uma } \\
\text { pedrinha em um deles. Brinca } \\
\text { de pular os outros. O último } \\
\text { quadrado chama-se "céu". Lá, } \\
\text { ele muda de direção. Na volta, } \\
\text { recolhe a pedrinha. }\end{array}$ & $\begin{array}{l}\text { (VALMONT) Ah, o } \\
\text { vislumbre de sua } \\
\text { virgindade me faz } \\
\text { esquecer o meu sexo e } \\
\text { me transforma na sua tia, } \\
\text { que me recomendou tão } \\
\text { calorosamente. }\end{array}$ & $\begin{array}{l}\text { Volange faceira } \\
\text { com o corpo, faz } \\
\text { uso da } \\
\text { sensualidade de } \\
\text { menina. Volange } \\
\text { é uma putinha, } \\
\text { uma perversinha. }\end{array}$ \\
\hline
\end{tabular}

Imagens resultantes de jogos de regras se transformaram junto `a enunciação do texto

A relação entre Merteuil e Valmont estava implicada bem como a idéia "é Merteuil quem representa Volange", "como uma putinha" (não estava em foco mas em jogo). Integradas `a escuta das falas de Valmont (Merteuil não tem falas nesta cena), as formas do corpo se transformaram e evocaram ação, bem como relação. O "pulinho do jogo da Amarelinha" (para mudar de direção quando se chega ao "céu"), se transformou: as nádegas ganharam ênfase e o olhar foi direcionado a ele, evocando "sedução". O jogo implicou certa dose de improviso: me joguei no colo dele. Três vezes seguidas ele me empurrou e me joguei. Logo veio a sentença: "De joelhos, pecadora. Conheço os sonhos que passeiam por seu sono. Arrependa-se e transformarei seu castigo em clemência". Me ajoelhei. Nos abraçamos com delicadeza: "Não tema por sua virgindade. A casa de Deus tem muitos aposentos".

De maneira que uma seqüência de ações foi evocada enquanto as imagens acústicas eram integradas `a partitura. Nos espaços de transição entre as formas partiturizadas (que estavam sendo transformadas), surgiam ações físicas espontâneas. Nestes momentos o repertório anteriormente decantado se inscreveu: o que foi visto (decantado ou desejado de alguma 
maneira). Ocorreu novo momento de criação de novas ações até chegarmos `a forma oriunda do "jogo do Samurai". A integração com o texto se deu em jogo (não foi calculada). São encontros acidentais. Determinadas imagens acústicas e determinadas formas físicas se integram.

A forma originária da "Amarelinha” também foi inscrita no Primeiro Monólogo de Merteuil em função da subpartitura "Deixa eu sonhar", que sustentava uma enunciação bastante longa. Em função de "fazer gestos grandes" e "ocupar todo o espaço", ocorreram transformações no tamanho, no contorno, na velocidade, na direção, e variações: "uma mão que se estende para um beijo", "um corpo que se deliquilibra e pende a cabeça para trás”, pulinhos, gargalhadas.

\begin{tabular}{|l|l|l|}
\hline \multicolumn{1}{|c|}{ FOCO } & \multicolumn{1}{|c|}{ TEXTO ENUNCIADO } & ESPONTÂNEO \\
\hline Subpartitura & Mesmo assim, houve minutos Talvez devesse dizer & Mão que se estende para \\
eu sonhar & momentos. Um minuto, isso sim é a eternidade, em que & um beijo, corpo que \\
& mim Valmont. Que sei eu dos seus sentimentos. E talvez & para trás, danças, \\
& devesse falar de momentos em que pude usá-lo. Isto é a & pulinhos, movimentos \\
& sua capacidade de mecher com a minha fisiologia. De & circulares e gargalhadas. \\
& sentir alguma coisa que na memória me parece um & \\
& sentimento de felicidade (...).
\end{tabular}

Ação física transformada quando inscrita no Monólogo de Merteuil: Segunda Modalidade

\subsubsection{Jogo Teatral}

"Construir um objeto com o corpo" é um jogo teatral proposto por Spolin $\left(^{\star}\right)$. Ao construir "uma flor", eu me equilibrava em uma das pernas e 
levantava os braços. A imagem foi partiturizada. Em jogo de enunciação a frase "Põe a mão madame no vazio entre as minhas coxas" se instalou bem nesta forma. O que era "flor" se transformou em "Merteuil pedindo a Valmont que tocasse seu sexo". Há um potencial dramático nas estruturas de jogos teatrais propostas por Spolin, bem como nas estruturas de jogos tradicionais.

\subsection{Mimesis de Figuras}

\subsubsection{Figuras Masculinas}

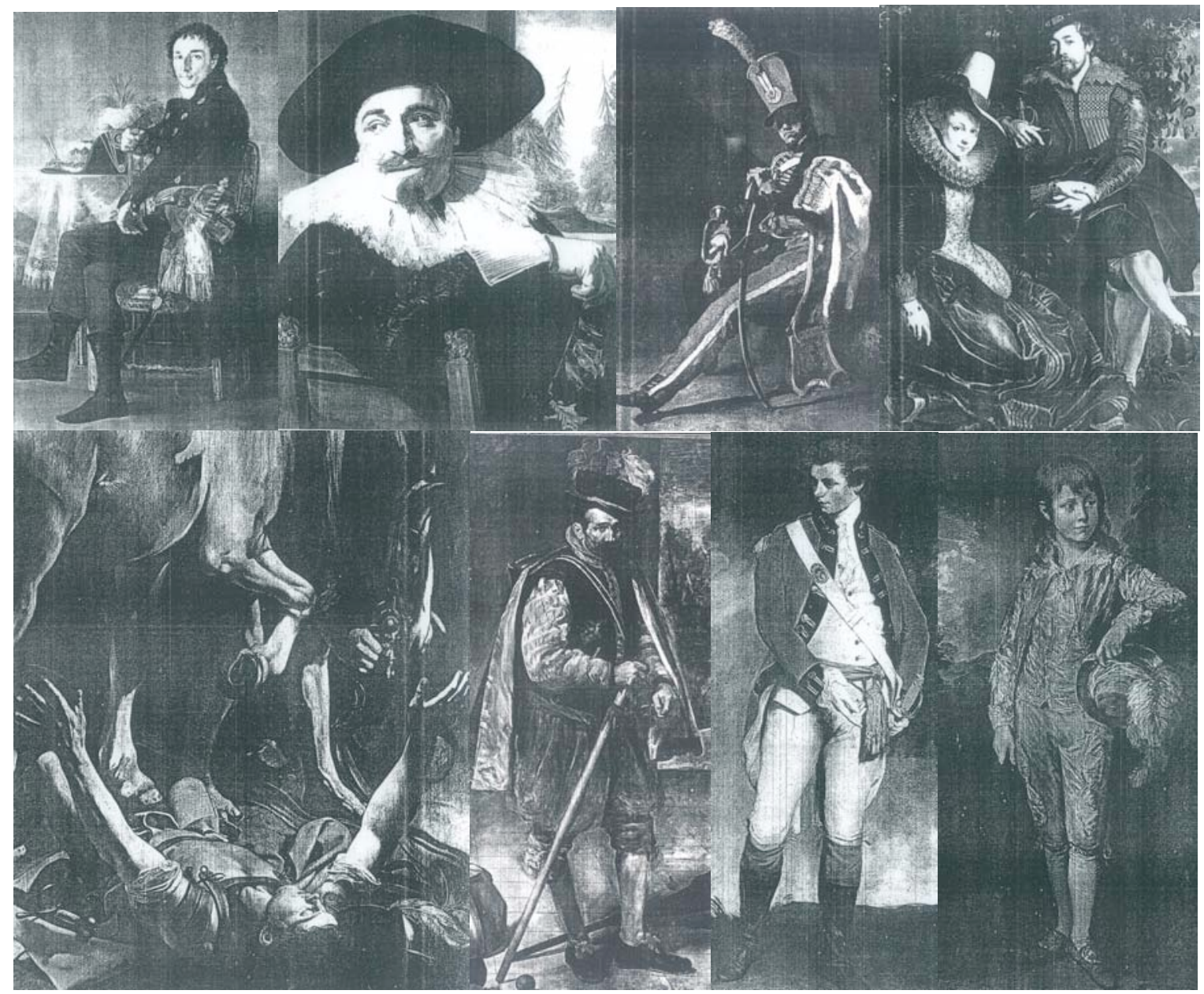

Partitura de Figuras Masculinas 
Introduzi "figuras masculinas" em jogo com uma pequena narrativa livre (cujo tema era "meu marido foi passear de barco com os amigos"). Surgiu uma forma particular de sentar-se. Em seguida, coloquei em jogo a enunciação. Trabalhamos com o revesamento entre duas partituras. Algumas frases se integraram `a partitura de mimesis de performance e outras `a partitura de figuras masculinas. As formas integradas `a primeira evocaram "sofrimento, inveja"; e as frases integradas `a segunda evocaram "ironia e deboche". O jogo criou contraste, oposição.

\begin{tabular}{|c|c|c|}
\hline FOCO & TRECHO DE QUARTETO ENUNCIADO & RESULTANTE \\
\hline $\begin{array}{l}\text { Revesamento } \\
\text { entre duas } \\
\text { partituras: a } \\
\text { partitura de } \\
\text { mimesis de } \\
\text { performance e } \\
\text { a partitura de } \\
\text { figuras } \\
\text { masculinas. }\end{array}$ & $\begin{array}{l}\text { Admito, é um potente pedaço de carne, mas dividida com um } \\
\text { esposo, enroscada com um esposo fiel, como tenho toda a } \\
\text { razão para temer, e isto há quantos anos. Que te resta, } \\
\text { Valmont? Um monte de merda. Seriamente, você quer cutucar } \\
\text { este resto opaco? Meus pêsames, Vamont. Se ela ainda fosse } \\
\text { uma puta que aprendeu sua profissão... A Merreau, por } \\
\text { exemplo, eu dividiria com dez homens. Mas a única dama da } \\
\text { sociedade que é suficientemente perversa a ponto de se } \\
\text { vangloriar no matrimônio, uma igrejeira de joelhos vermelhos do } \\
\text { banco de igreja e com os dedos inchados de tanto suplicar } \\
\text { diante de seu confessor? Estas mãos não tocam um órgão } \\
\text { genital, Valmont, sem a bênção da igreja. Aposto que ela sonha } \\
\text { com a Imaculada Conceição, quando seu querido esposo se } \\
\text { digna com a intenção matrimonial de Ihe fazer um filho, uma vez } \\
\text { por ano." }\end{array}$ & $\begin{array}{l}\text { Certa forma de } \\
\text { sentar-se e } \\
\text { falar; registros } \\
\text { de rivalidade, } \\
\text { ironia, deboche } \\
\text { (com uma } \\
\text { partitura) e de } \\
\text { inveja doentia e } \\
\text { desespero (com } \\
\text { a outra } \\
\text { partitura): } \\
\text { relação com } \\
\text { Turvel. }\end{array}$ \\
\hline
\end{tabular}

Primeira modalidade de jogo de enunciação com a transformação da partitura em foco

Na Segunda Modalidade de Jogo a "forma de sentar-se" se instalou em função da subpartitura "Interesseiro" e o texto enunciado "Eu dava por 
acabada essa sua paixão por mim. Qual a origem deste repentino recrudescer?". Novas associações (com "mulher grávida" e "bailarina") se instalaram. Elementos relativamente autônomos foram integrados. $A$ posteriori, a leitura da ação. A relação com Valmont estava em jogo.

\subsubsection{Figuras em Dupla}

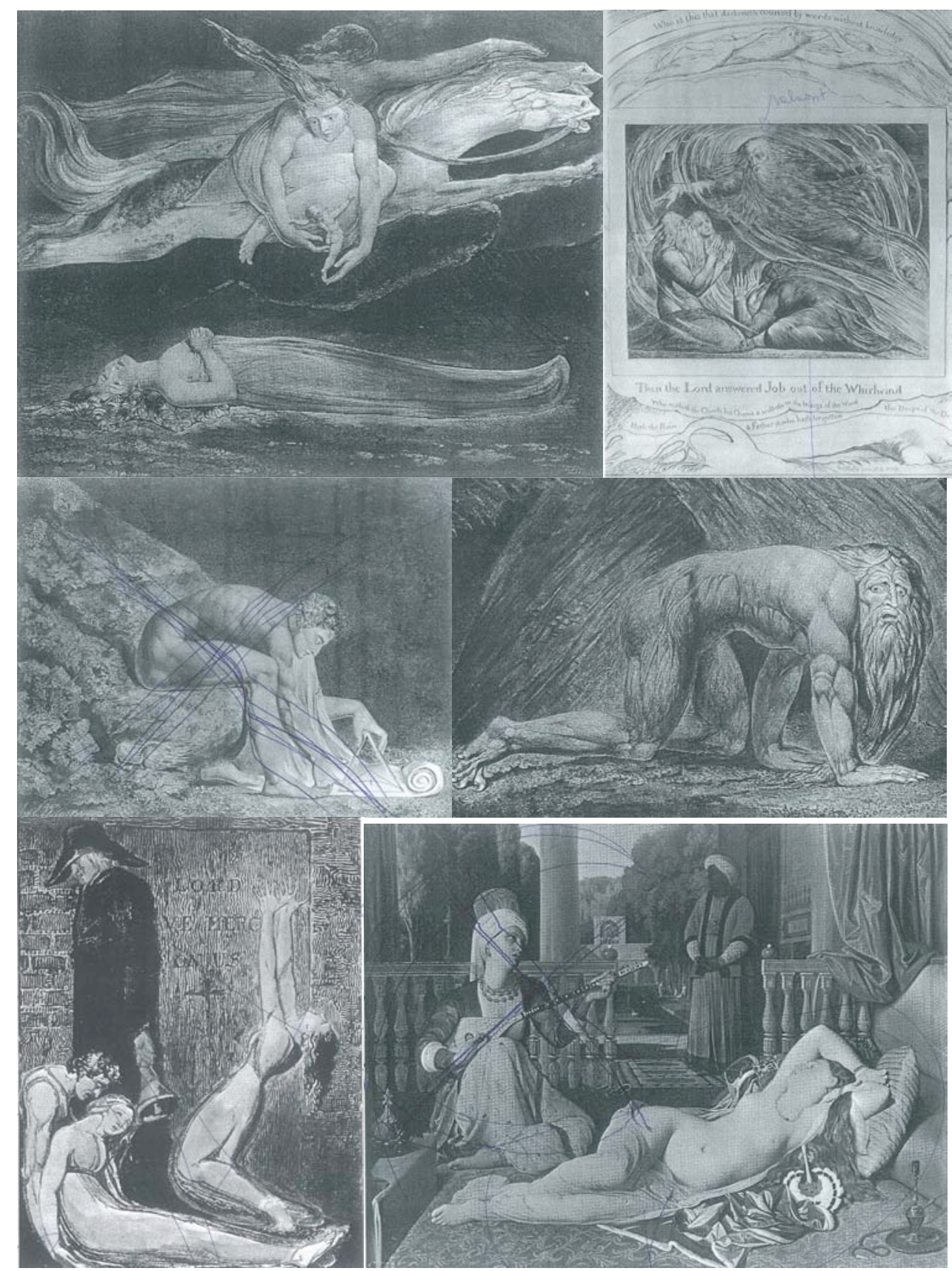




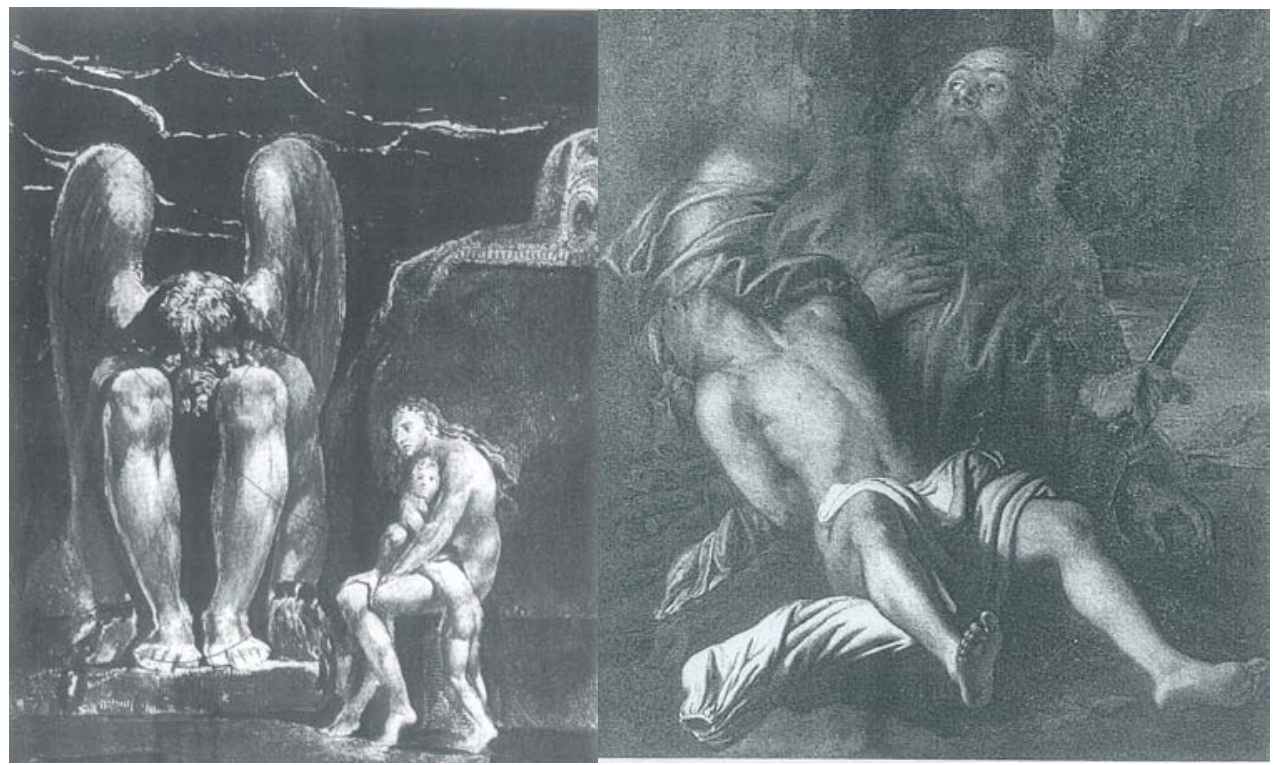

Partitura de Figuras em Duplas

A seqüência de figuras em dupla originou sucessivas trocas de lugar, aproximações, afastamentos, transferências de peso, planos altos e baixos, encaixes e desencaixes, e um deslocamento de joelhos, em plano baixo. Os movimentos foram integrados `a enunciação de um trecho em que Valmont falava sobre o vazio. As ações foram evocadas nos momentos de troca entre uma posição do corpo e outra. Ações como "Merteuil no colo de Valmont" e, depois, "ele sentado no chão, com a cabeça encostada em seu joelho".

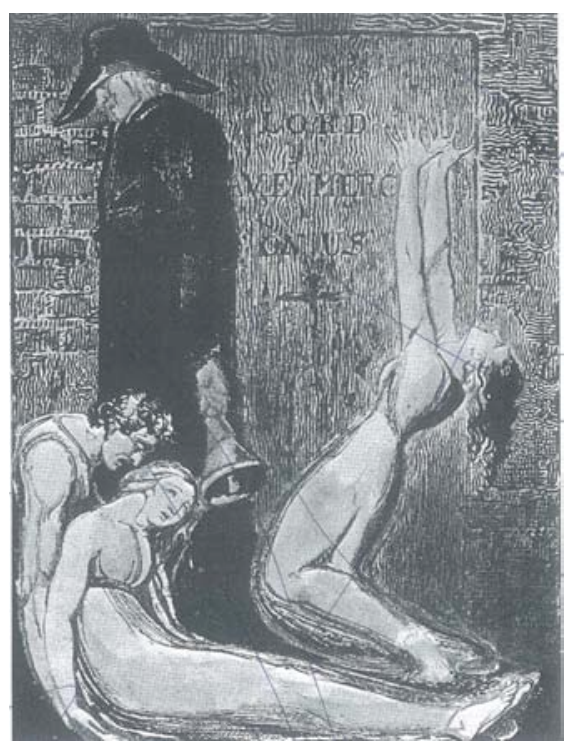


$\mathrm{Na}$ atividade construída a partir da figura acima, Valmont passou da posição "em pé, de costas para a mulher" (figura com chapéu), enunciando "Detesto o passado. Imagina, ter de conviver com o lixo dos nossos anos", para o plano baixo, onde "ampara a mulher", enunciando "Ou na secreção de nossos corpos. Só a morte é eterna, a vida se repete até o bocejo do abismo". As sentenças se acomodaram nas atividades cênicas com as quais evocaram ação.

\subsubsection{O Esquecimento como Auxiliar}

Utilizamos o "esquecimento" como auxiliar do encontro com novas ações. O "esquecimento" causa "fissura" no encadeamento acústico. O fio contínuo dos sons entrelaçados se rompe de repente. Inevitavelmente é preciso elaborar uma volta. Esta volta inscreve-se como novo impulso. De maneira que os "esquecimentos" são produtivos. É possível construir um elemento novo. A sensação do ator é de profunda fragilidade. Se ele sustenta o jogo, pode transformar o "colapso" em ação "da personagem". De maneira que produz na medida em que se descobre sujeito a acidentes. Em um momento em que nada há de concreto, ele cria.

\section{Exemplo 1:}

O jogo com a partitura física produziu a atividade "sentar-se". Esta atividade evocou a presença de um espelho e "Merteuil e Valmont diante do espelho". A sentença que se acomodou e ajudou a evocar esta ação foi: " $E$ a 
epidemia de espermas para todo aquele que nos escapa com alguma serenidade da fincada das pontas de espadas e do relâmpago do fogo da boca de canhão". Ocorreram sucessivos "esquecimentos" e a sentença foi enunciada aos pedacinhos: um pedacinho e uma pausa, mais um pedacinho e uma pausa, mais um pedacinho e uma pausa. A tensão provocada evocou a ação: "enfrentar, juntos, o espelho" (bem como a agressividade e o erotismo).

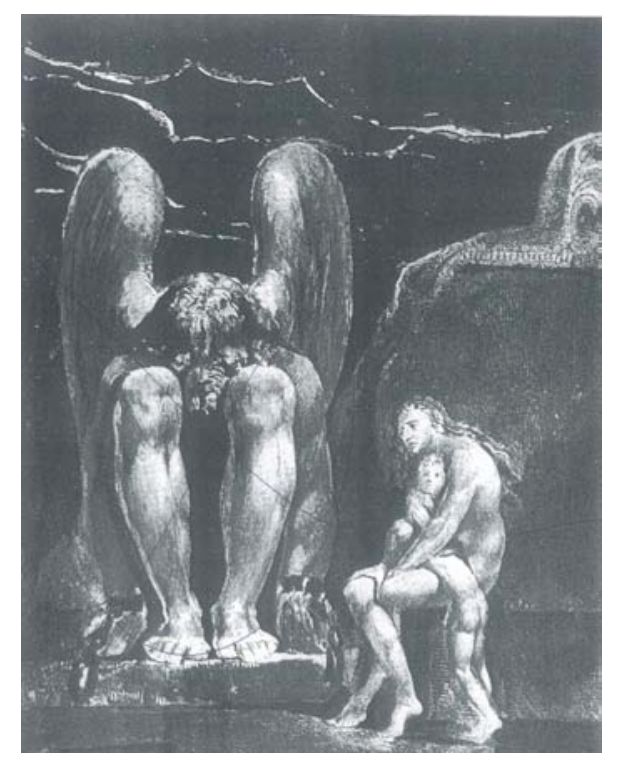

Imagem que originou a ação "enfrentar o espelho"

Com a repetição, a frase passou a ser lembrada com facilidade e o problema do "esquecimento" terminou. A ação "enfrentar o espelho" se deslocou e integrou-se `a frase seguinte: "O que diz seu espelho? Sempre é o outro que nos encara. É este quem procuramos, quando nos revolvemos entre os corpos estranhos, fugindo de nós mesmos. Pode ser que não exista nem um nem outro, somente o nada em nossa alma, que cacareja por ração". Com as repetições esta ação também foi absorvida. A qualidade da enunciação tornou-se doce, íntima. A partitura continuava se transformando. 


\section{Exemplo 2:}

Em meio `a frase "Tarde demais no que se refere ao nosso terno relacionamento" o esquecimento foi abrupto. A frase foi dividida em duas partes: "Tarde demais (esquecimento) no que se refere ao nosso terno relacionamento". TAAARDJIDJIMAAAAIIIIS integrou-se a primeira parte da partitura e evocou "Valmont avança agressivamente para Merteuil". Já a segunda parte, integrada ao movimento "sentar-se", evocou intimidade e contenção, bem como a divisão: NUQUISIREFERI / AUNOSSUTERNU / RELACIONAMEINTU. Com a recuperação da memória a tendência foi unir novamente as duas partes e perder o desenho já constituído.

\subsection{Associações Cotidianas}

\subsubsection{Mimesis}

"Ações cotidianas" são imagens do corpo cotidiano escolhidas a partir da observação. O procedimento: observar pessoas $e$ isolar as imagens, nomeando-as e ordenando-as (pela escrita). Isoladas do contexto original são tomadas como atividades a serem introduzidas em jogo.

\begin{tabular}{|l|l|}
\hline & \multicolumn{1}{|c|}{ AS IMAGENS ESCOLHIDAS FORAM PARTITURIZADAS } \\
\hline 1. & Arrumar a manga da camisa \\
\hline 2. & Voltar a cabeça \\
\hline 3. & Olhar para o lado \\
\hline 4. & Apoiar o antebraço na mesa segurando a chave \\
\hline 5. & Apoiar o cotovelo esquerdo \\
\hline 6. & Mexer no cabelo \\
\hline
\end{tabular}




\begin{tabular}{|c|l|}
\hline 7. & Apoiar a mão na coxa \\
\hline 8. & Mexer os dedos \\
\hline 9. & Mexer na camisa \\
\hline 10. & Bater na perna \\
\hline 11. & Virar a cabeça para o lado \\
\hline 12. & As duas mãos no colo \\
\hline 13. & Duas mordidinhas no chiclete \\
\hline 14. & Apoiar os antebraços na mesa \\
\hline 15. & Ficar olhando os papeizinhos \\
\hline 16. & Balançar o "todynho" para o lado \\
\hline 17. & Balançar o "todynho" para a frente \\
\hline 18. & Mão esticada, mão direita por cima balançando a chave \\
\hline 19. & Segurar o punho \\
\hline 20. & Balançar a mão do punho \\
\hline 21. & Balançar a perna (agitada) / braço para baixo \\
\hline
\end{tabular}

Partitura de Atividades Cotidianas

\section{A partitura integrou-se ao trecho que vem logo após a chegada de}

Valmont e a revelação do nome "Turvel". Merteuil fala sobre o jovem amante.

Ciumento, você, Valmont. Que recaída. Eu entenderia se você o conhecesse. Além disso, estou certa de que você já o encontrou. Um belo homem. Embora não muito diferente de você. As aves de arribação também revoluteiam na rede do hábito, mesmo quando o seu vôo se estende por continentes inteiros. Dê uma volta. A vantagem dele é a sua juventude. Também na cama, se quer saber. Quer saber. Um sonho, se tomo você como realidade, Valmont. Perdão. Daqui a dez anos, talvez nada te diferencie, contanto que eu possa te transformar em pedra ou em outro material mais solicito, agora com um suave olhar de medusa. Uma fantasia frutífera: o museu dos nossos amores. Teríamos a casa cheia, não é, Valmont? Como a coluna de nossos desejos apodrecidos. Os sonhos mortos, em ordem alfabética ou cronológica, livre dos acasos da carne, não mais expostos aos sustos da transformação. Nossa memória precisa de muletas; não se lembra nem mesmo da sinuosidade diferente dos rabos, para já não falar dos rostos: um vapor. A Tourvel é uma ofensa. Não te dei a liberdade para trepar com esta vaca, Valmont (1).

1. MÜLLER, Heiner. Quatro Textos para Teatro: Mauser, Hamlet-máquina, A Missão, Quarteto. São Paulo: Hucitec, 1987, pg. 60. 
As atividades foram absorvidas com música e qualidades físicas ( $\left.{ }^{*}\right)$.

Este primeiro exercício originou movimentos sinuosos, por vezes tremores. A ação inscrita foi "colocar ciúmes em Valmont" (enquanto descreve o amante). A repetição da palavra "você", junto a certa ocilação no endereçamento da fala (para "Valmont real" ao seu lado ou para a imagem no espelho onde estaria refletida a sua imagem travestida de "Valmont personagem") inscreveu ação: eles se preparam para o "número" O Assédio a Turvel (vivido por MerteuilValmont): "Ciumento, VOCÊ, Valmont. Que recaída. Eu entenderia se VOCÉ o conhecesse. Além disso, estou certa de que VOCÊ já o encontrou. Um belo homem. Embora não muito diferente de VOCÉ.".

A nova imagem combinou-se `a resultante do jogo com o percurso 1. Enquanto reage ao nome "Turvel", Merteuil "busca o vestido de Valmont" para que ele se prepare para o número que encenarão. A ação "colocar ciúme" também se desenvolveu: Merteuil utiliza o "personagem“ (Valmont do passado, que via no espelho) para provocar "Valmont". Pois o "seu" Valmont era muito melhor que ele: era jovem, belo, libertino e pérfido. As ações encadearam. Certas imagens, pedaços, fragmentos, ganharam consistência. Em seguida, Merteuil falava sobre "o museu dos seus amores".

Uma fantasia frutífera: o museu dos nossos amores. Teríamos a casa cheia, não é, Valmont? Como a coluna de nossos desejos apodrecidos. Os sonhos mortos, em ordem alfabética ou cronológica, livre dos acasos da carne, não mais expostos aos sustos da transformação (1).

(*) Foi interessante perceber que quando partiturizadas as atividades deixaram de inscrever o registro cotidiano. Observando as descrições de María Knébel dos exercícios realizados com os atores, percebemos que o registro cotidiano lança mão de operações específicas, como a construção de um pensamento "distante", "em outro lugar" (enquanto as atividades estão sendo realizadas "automaticamente"), bem como a percepção de tudo o que se vê, ouve, toca em cena. A descrição destas operações está em KNÉBEL, op. cit., pgs 36-60.

1. MÜLLER, Heiner, op. cit., pg. 60. 
O trecho é finalizado com "Nossa memória precisa de muletas; não se lembra nem mesmo da sinuosidade diferente dos rabos, para já não falar dos rostos: um vapor". Neste instante, o retorno ao assunto "Turvel" provocou nova associação com "a carta" (Merteuil encontra as cartas): "A Tourvel é uma ofensa. Não te dei a liberdade para trepar com esta vaca, Valmont".

\subsubsection{Imagem Acústica}

O envolvimento com o processo de construção cênica provocou associações com o corpo da atriz circunstanciado pelo cotidiano. Imagens foram evocadas de situações em que o corpo estava colocado em determinada forma (que não implicavam o contexto ficcional, mas associavam a produção cênica, talvez a partir do desejo de levar as imagens deste corpo `a cena). Estas associações foram espontâneas.

Das atividades deste "corpo cotidiano" criei uma seqüência de imagens acústicas: "Ficar bem parada, compenetrada, olhado para fora. Uma janela." Memorizei esta seqüência pela escrita e a coloquei em jogo para introduzir o Primeiro Monólogo de Merteuil (primeira ação da cena, antes da enunciação). As imagens acústicas conduziram o corpo e a resultante evocou "ficar compenetrada no barulho repentino das bombas" (porque havia uma guerra fora do bunker onde Merteuil estava).

$\mathrm{Na}$ medida em que elementos ficcionais estavam implicados e imagens concretas começavam a ser delineadas, as transformações se davam com maior facilidade. A interpretação não pretendeu, no entanto, dar conta da totalidade do texto. Contemporaneamente se pode dizer que a 
estrutura dramática articula diferentes narrativas $\left({ }^{*}\right)$. Desenhamos aquela por

onde passa nossa fala e que implica o sentido de nossa construção.

Cada narrativa parece ter alguma coisa demais, um escedente, um suplemento, que fica fora da forma fechada produzida por seu desenrolar. (...) esse algo mais próprio da narrativa é também algo menos; o suplemento é também uma falta; para suprir a falta criada pelo suplemento, uma outra narrativa se faz necessária. (1)

Haverá sempre a perspectiva de novas combinações: "A vertigem

das narrativas se torna angustiante; e nada escapa mais ao mundo narrativo, recobrindo o conjunto da experiência" (idem: 126); "(...) e não há nenhuma razão para que isso pare em algum ponto (...) sempre haverá um suplemento que espera uma narrativa futura" (idem: 131).

1. TODOROV, Tristan. As Estruturas Narrativas, São Paulo: Perspectiva, 2003, pg. 131. $\left({ }^{*}\right)$ A questão do texto dramático articular diferentes encadeamentos narrativos foi explorada por Anne Ubersfeld. Segundo ela esta é uma questão implicada na própria estrutura do texto, que é "actancial". A estrutura actancial possui seis casas: sujeito e objeto (que formam o eixo da narrativa), e mais quatro: adjuvante (que ajuda a ação), oponente (que atrapalha a ação), destinatário (para quem a ação é dirigida, que se beneficia da ação) e destinador (quem ordena a ação). De maneira que a relação direta "sujeito-objeto" se perde. Os elementos que "ocupam" as seis casas (os seis "lugares" da estrutura actancial), são chamados "actantes", e podem ser tanto um "nome próprio" (Merteuil) quanto um elemento abstrato ("o rancor de Merteuil", por exemplo, enquanto "seu amor por Valmont" ocupa outra casa). Neste sentido, a "personagem" é "espatifada", "explodida". Não é possível que se configure como indivíduo autônomo. A idéia de que "uma pessoa age" é apenas referencial (o que ela chama de "ilusão referencial necessária"). Segundo Ubersfeld, ao longo da estrutura dramática, os actantes se revesam na estrutura, mudam de lugar, compondo combinações actanciais diferentes (o que ela chama de "modelos actanciais"), de maneira que muitas narrativas são engendradas, se revesam e se recombinam em um mesmo texto dramático, o que denota complexidade. A ênfase dada a uma ou a outra narrativa é uma questão que permeia a encenação e implica o investimento de uma "fala" (desejo), bem como condições de enunciação especiais de cada processo (Ver UBERSFELD, Para Ler o Teatro. São Paulo: Perspectiva, 2005). A instância "personagem" foi construída, modelada, forjada de diversas maneiras na história do teatro: "Força passional em Shakespeare, teve dificuldade para constituir-se indivíduo livre e autônomo. $\mathrm{Na}$ era clássica francesa, curva-se ‘as exigências abstratas de uma ação universal ou exemplar, sem possuir os caracteres de um tipo social definido (...) Com DIDEROT e seu drama burguês a personagem passa a ser uma condição (...) calcada no real, evolue até o naturalismo e os primórdios da encenação. Nesse momento, a tendência se inverte e a personagem tende a dissolver-se no drama simbolista, no qual o universo é povoado apenas por sombras, cores e sons que se correspondem (MAETERLINCK, STRINDBERG, CLAUDEL). A seguir, se estilhaça na dramaturgia épica dos expressionistas e de BRECHT: esta desmontagem da personagem, totalmente entregue 'as necessidades da fábula, da historicização e da desconstrução do real a ser criticado, marca o remate de sua "encenação". O início de certo recentramento faz-se sentir com a personagem surrealista, onde sonho e realidade se entremesclam, a personagem autoreflexiva (PIRANDELLO, GENET) na qual os níveis de realidade se embaralham nos jogos de teatro dentro do teatro e de personagem dentro da personagem (PAVIS, idem: 285-286). 


\section{Capítulo 3}

\section{Segunda Modalidade de Jogo}

Qualquer que seja a estética da encenação deve existir uma relação entre a partitura e a subpartitura, os pontos de apoio, a mobilização interna do ator

Barba

O efeito de verdade buscado por Stanislavski, a teatralidade buscada por Meyerhold, o efeito de estranhamento buscado por Brecht indicam objetivos opostos em termos de resultado, mas não divergentes no processo. Estes diferentes objetivos pressupõe, por trás da coerência da ação externa da partitura, uma coerente organização da subpartitura, de um "forro do pensamento" que o

ator controla. Ela (a subpartitura) é constituída por imagens circunstanciadas ou por regras técnicas, por experiências ou perguntas feitas a si mesmo, ou por ritmos, modelos dinâmicos ou por situações vividas ou hipotéticas.

Barba

Não é a partir da reflexão ou do raciocínio lógico que se consegue encontrar a resposta de uma pergunta enigmática. A resposta surge literalmente numa solução brusca - o desfazer dos nós em que o interrogador tem preso o interrogado. 


\title{
3.1. Criação e Memorização das Palavras Inventadas
}

\author{
A fala da personagem - fala por trás da qual não há nenhuma pessoa, \\ nenhum sujeito - impele, por meio desse vazio mesmo, e pelo desejo que \\ suscita, a nele investir a própria fala. \\ Ubersfeld \\ El arte comienza en el momento en que el personaje desaparece y queda \\ el "yo" circunstianciado por al pieza.
}

Toporkov

\begin{tabular}{|l|l|l|l|}
\hline \multicolumn{1}{|c|}{1} & \multicolumn{1}{|c|}{2} & \multicolumn{1}{|c|}{3} & \multicolumn{1}{c|}{4} \\
\hline Memorização & Jogos de enunciação, & Passar o texto na & O revesamento é \\
criação da imagem & físico, absorção, tônus, & engaja. Palavras inventadas & escrita. Criação de \\
acústica do texto- & imagens da ficção; & em revesamento com o texto & regras que \\
dado, atividade & retorno `a escrita, & são escolhidas na medida & organizam o corpo \\
interna, imagens, & leituras, novas & em que reforçam a atividade & no espaço. \\
associações. & associações. & interna. & \\
\hline
\end{tabular}

Etapas preparatórias para a Segunda Modalidade de Jogo: construção da subpartitura

\subsubsection{A Criação das Palavras}

A escolha das "palavras inventadas" foi realizada "sem os outros

perceberem".

Sem que os outros percebam, pode-se treinar as ações físicas, e fazer as composições das ações físicas permanecendo no nível dos impulsos. Isso que dizer que as ações ainda não aparecem mas estão no corpo, porque são im/pulso. Por exemplo: em um momento de meu personagem estou em um jardim sentado em um banco, alguém senta-se ao meu lado, eu o olho. Agora trabalho sobre este momento sozinho. Exteriormente - não estou olhando esta pessoa - faço somente o ponto de partida, o impulso de olhálo. Do mesmo modo executo o impulso de inclinar-me, de tocar a sua mão (o que Grotowski faz é quase imperceptível), mas não o faço parecer plenamente uma ação (...) Mas não a exteriorizo. Agora caminho, caminho,... mas permaneço na minha cadeira. É somente assim que se pode treinar as ações físicas. Mas há mais; as vossas ações físicas serão assimiladas ainda mais pela vossa natureza se treinarem os impulsos, não as ações. Podemos dizer que a ação física quase nasceu, mas ainda é bloqueada, e assim, no nosso dizer, estamos "impostando" uma reação justa, assim como se imposta a voz. (1)

1. RICHARDS, 1993: 94 upud BONFITTO, 2007: 74. 
Brincando de "pensar o texto" na imobilidade, fui experimentando outras palavras, outras sentenças: "Idiota" ao invés de "Valmont", "Olha a hora" no lugar de "Não conseguirá mais inflamar meu coração". Experimentei o revesamento entre estas "sentenças inventadas" e as sentenças do textodado. Na medida em que a atividade interna era mantida, as novas sentenças eram escolhidas para a subpartitura (na medida em que "me levavam" da mesma maneira que o texto "me levava"). Se a atividade interna diminuia, eram imediatamente substituídas. Outras eram experimentadas e partiturizadas em seu lugar. De maneira que o procedimento resultou em um encadeamento de sentenças, intercaladas, em determinada ordem, aos trechos do texto-dado. Uma "estrutura rítmica" de revesamento entre dois elementos. As "palavras inventadas" não poderiam ser enunciadas: era a regra. Isto traria implicações pois é com esta palavra que me envolvo (é ela que entra em foco antes de ser "substituída" pela sentença do texto-dado).

\begin{tabular}{|l|l|}
\hline \multicolumn{1}{|c|}{ TEXTO INVENTADO } & \multicolumn{1}{c|}{ TEXTO ENUNCIADO } \\
\hline Idiota! & Valmont \\
\hline Nós somos terríveis! & (Pausa) \\
\hline É a minha chance! & Eu dava por acabada essa sua paixão por mim. \\
\hline Interesseiro! & Qual a origem desse repentino recrudescer. \\
\hline Você não me engana! & E com tanta força junenil. \\
\hline Olha a hora! & Tarde demais porém. Não conseguirá inflamar meu coração. Nem \\
ainda mais uma vez. Nunca mais. \\
\hline Me perdoe, eu também errei! & Não Ihe digo isso sem pesar Valmont. \\
\hline
\end{tabular}




\begin{tabular}{|c|c|}
\hline Deixa eu sonhar! & $\begin{array}{l}\text { Mesmo assim, houve minutos. Talvez devesse dizer momentos. } \\
\text { Um minuto. Isso sim é a eternidade. Em que me senti feliz. } \\
\text { Graças a sua companhia. Estou falando de mim Valmont. (...) Não } \\
\text { esqueceu como tratar esta máquina. Não retira a sua mão. Não } \\
\text { que eu sinta alguma coisa por você. É a minha pele que se } \\
\text { lembra. E simplesmente para ela tanto faz, de que forma ou em } \\
\text { que animal está fixado o instrumento de sua volúpia, mão ou } \\
\text { garra. }\end{array}$ \\
\hline Desisto! & $\begin{array}{l}\text { Quando eu fecho os olhos você é bonito Valmont, ou corcunda se } \\
\text { eu desejar. Ah, o privilégio dos cegos. Você é mais feliz no amor. } \\
\text { Vê o que quer ver. A comédia dos sintomas lhe é poupada. O } \\
\text { melhor seria ser cego e surdo e mudo. A paixão das rochas. }\end{array}$ \\
\hline Tô bêbada! & $\begin{array}{l}\text { Eu te assustei, Valmont. Como você é fácil de desanimar. Não o } \\
\text { conhecia assim. }\end{array}$ \\
\hline Filho da puta! & As damas depois de mim lhe deixaram mágoas? \\
\hline Bem feito! & Lágrimas? \\
\hline Ele está apaixonado! & Você tem um coração Valmont? Desde quando? \\
\hline Não pode ser! & Ou será que a sua virilidade estragou com as minhas sucessoras. \\
\hline Pera aí! & Ou a sucessora de minha sucessora te mandou passear. \\
\hline Pera aí! & O amante abandonado. \\
\hline Pera aí! & $\begin{array}{l}\text { Não. Não retire sua tenra oferta meu amando senhor. Eu cumpro. } \\
\text { Eu cumpro de qualquer modo. }\end{array}$ \\
\hline Que merda! & $\begin{array}{l}\text { A paixão dos corpos. O martírio de viver e não ser Deus. Ter } \\
\text { consciência e nenhum poder sobre a matéria. Não há sentimentos } \\
\text { a temer. Nunca te amei como posso te odiar. Rocemos nossa } \\
\text { pele uma contra a outra. }\end{array}$ \\
\hline
\end{tabular}




\begin{tabular}{|l|l|}
\hline Que merda, que merda, que & Não se precipite Valmont, assim está bem. \\
\hline Que merda! & Sim. \\
\hline Que merda! & Sim. \\
\hline Que merda! & Sim. \\
\hline Que merda! & Sim. \\
\hline Que merda.... & Isto foi bem encenado não é? \\
\hline Só vou te amar depois de & A paixão do meu corpo não me interessa. Não sou nenhuma \\
morto! & $\begin{array}{l}\text { criada de estábulo. Estou completamente fria Valmont. Minha } \\
\text { vida, minha morte, meu amado. }\end{array}$ \\
\hline (As palavras inventadas foram escolhidas na medida em que prolongavam e reforçavam a atividade \\
\hline
\end{tabular}

\subsubsection{Memorização da Subpartitura Através da Escrita}

As sentenças da subpartitura intercaladas `as sentenças do textodado foram memorizadas pela escrita. O registro escrito do "intercalamento" foi repetido até a efetiva memorização: até a desestruturação da escrita, de maneira a constituir uma "malha acústica" contínua. Foram decantadas "suturas", imagens, ritmo, atividade interna (da mesma maneira que aconteceu com a primeira aplicação da Memorização Através da Escrita). As imagens se tornaram concretas, situaram o foco e carregaram o corpo. A velocidade da "mão que escreve" não acompanhou e a caligrafia borrou. Os últimos fonemas de cada "sentença inventada" resultaram "costurados" nos primeiros fonemas de cada sentença subseqüente a ser enunciada em cena. 
Como TAVAL, que une IDJIOTA e VAUMOUM, de maneira que o foco em IDJIOTA provocava a enunciação inevitável de VAUMOUM.

\begin{tabular}{|l|l|c|}
\hline \multicolumn{1}{|c|}{ REGISTRO ESCRITO } & \multicolumn{1}{|c|}{ MALHA ACÚSTICA CONTÍNUA } & SUTURAS \\
\hline (inventada) Idiota (texto) Valmount & IDJIOTAVAUMOUM & TAVAL \\
\hline (texto) Valmont (inventada) Nós & VAUMOUMOUMNÓISSOMUSTERRI & MOUMNÓIS \\
somos terríveis (texto) Eu dava por & VEISSEUDAVAPURACABADASUAPAI & SEUDAVA \\
acabada essa sua paixão por mim & CHÃUMPURMINHÉAMINHACHANCI & NHÉAMI \\
(inventada) É a minha chance. & & \\
\hline
\end{tabular}

(Cada sentença inventada na frente da sentença do texto para qual sustenta o foco em cena).

\begin{tabular}{|l|l|c|}
\hline \multicolumn{1}{|c|}{ REGISTRO ESCRITO } & \multicolumn{1}{|c|}{ MALHA ACÚSTICA CONTÍNUA } & SUTURA \\
\hline Texto e sentença inventada & O texto desemboca na sentença inventada: & NHÉAMI \\
seqüenciados: (texto) Paixão por mim & "PAICHÃUMPOURMINHÉAMINHACHANCl" & \\
(subpartitura) É a minha chance. & & \\
\hline
\end{tabular}

(Sentença do texto-dado suturada na próxima sentença inventada a entrar em Foco)

\subsection{Jogo com a Subpartitura}

\subsubsection{A Estrutura de Regras}

Duas regras ("fazer gestos grandes" e "ocupar bem o espaço") dividiram o foco com "sentenças inventadas". A cada "sentença inventada" que situou o foco, uma ação física apareceu (obedecendo, também, a "fazer gestos grandes" e "ocupar todo o espaço"). A ocilação do foco entre as duas regras inscreveu constantes deslocamentos do corpo no espaço, que contou, por sua vez, com o repertório de ações físicas para as mudanças de direção e localização: sentar-se, levantar-se, caminhar, parar, subir na mesa, descer da mesa. 
Antigas ações físicas foram presentificadas: o tempo sustentado pelo envolvimento com as sentenças inventadas ("Idiota", "Nós somos terríveis", "Desisto"). Terminado o tempo de sustentação de cada sentença, "apareceu" aquela a ser enunciada. Primeiro a ação física nasceu e se desenvolveu (foco na subpartitura) para depois o texto ser enunciado. O texto inscrito como segundo termo evocou associações.

\subsubsection{O Encadeamento}

As ações físicas apareceram na medida em que auxiliaram a resolução do problema. Como "fazer gestos grandes"? Com ações físicas. Como "ocupar todo o espaço"? Com ações físicas. Se instalaram no lugar do instantâneo. Se inscreveram como impulso na medida em que "ocupar todo o espaço" e "fazer gestos grandes" se revesaram constantemente no foco.

\begin{tabular}{|l|l|l|l|}
\hline SUBPARTITURA & \multicolumn{1}{|c|}{ AÇÃO FÍSICA } & TEXTO DADO & AÇÃO \\
\hline Idiota! & $\begin{array}{l}\text { Forma de "empurrar o ar" para a } \\
\text { diagonal esquerda baixa, } \\
\text { revesando as mãos, velocidade } \\
\text { e tônus alterados (resultante da } \\
\text { mimesis de performance). }\end{array}$ & Valmont. & Afastá-lo, \\
recusá-lo, \\
terríveis! & $\begin{array}{l}\text { Um balancinho do corpo, } \\
\text { pequenos movimentos em } \\
\text { estacato, mãos ajeitam a roupa, } \\
\text { a postura, o queixo levantado } \\
\text { (resultante da mimesis de } \\
\text { performance). }\end{array}$ & chilique, \\
\hline
\end{tabular}




\begin{tabular}{|c|c|c|c|}
\hline Interesseiro! & $\begin{array}{l}\text { Jeito de sentar. Pernas "em } \\
\text { quarta posição", mão acima da } \\
\text { cabeça, o dedo circula, o corpo } \\
\text { frontal para a platéia, olhar para } \\
\text { o infinito (resultante da partitura } \\
\text { de imagens masculinas). }\end{array}$ & $\begin{array}{l}\text { Eu dava por acabada essa } \\
\text { sua paixão por mim. Qual a } \\
\text { origem desse repentino } \\
\text { recrudescer (...). }\end{array}$ & $\begin{array}{l}\text { Questionar } \\
\text { Valmont. }\end{array}$ \\
\hline $\begin{array}{l}\text { Você não me } \\
\text { engana! }\end{array}$ & (Idem). & $\begin{array}{l}\text { (...) e com tanta força } \\
\text { junenil? }\end{array}$ & (Idem). \\
\hline Olha a hora! & $\begin{array}{l}\text { Em sobressalto, o dedo em riste } \\
\text { (resultante da mimesis de } \\
\text { performance + estacato + } \\
\text { susto). }\end{array}$ & $\begin{array}{l}\text { Tarde demais porém. Não } \\
\text { conseguirá inflamar meu } \\
\text { coração. Nem ainda mais } \\
\text { uma vez. Nunca mais. }\end{array}$ & $\begin{array}{l}\text { Assustar-se, } \\
\text { escapar. }\end{array}$ \\
\hline $\begin{array}{l}\text { Me perdoe, eu } \\
\text { também errei! }\end{array}$ & $\begin{array}{l}\text { Caminhada lenta até virar-se, } \\
\text { abre os braços (partitura de } \\
\text { mimesis + "idéia de peso"). }\end{array}$ & $\begin{array}{l}\text { Não lhe digo isso sem pesar } \\
\text { Valmont. }\end{array}$ & $\begin{array}{l}\text { Resignar-se, } \\
\text { tornar-se } \\
\text { humilde. }\end{array}$ \\
\hline Deixa eu sonhar! & $\begin{array}{l}\text { Variações de tamanho, } \\
\text { velocidade, direção e forma da } \\
\text { resultante da "Amarelinha". }\end{array}$ & $\begin{array}{l}\text { Mesmo assim, houve } \\
\text { minutos, talvez devesse } \\
\text { dizer momentos. Um minuto. } \\
\text { Isso sim é a eternidade. (...) } \\
\text { Não retira a sua mão. Não } \\
\text { que eu sinta alguma coisa } \\
\text { por você. É a minha pele } \\
\text { que se lembra. }\end{array}$ & $\begin{array}{l}\text { Seduzir } \\
\text { Valmont. }\end{array}$ \\
\hline Deixa eu sonhar & $\begin{array}{l}\text { As "mãos em forma de garra" } \\
\text { sobre o contorno do corpo } \\
\text { (mimesis de performance + } \\
\text { Klimt). }\end{array}$ & $\begin{array}{l}\text { E simplesmente para ela } \\
\text { tanto faz de que forma ou } \\
\text { em que animal está fixado o } \\
\text { instrumento de sua volúpia, } \\
\text { mão ou garra. }\end{array}$ & $\begin{array}{l}\text { Rasgar a } \\
\text { pele, a } \\
\text { roupa, } \\
\text { bancar a } \\
\text { revolta. }\end{array}$ \\
\hline
\end{tabular}




\begin{tabular}{|c|c|c|c|}
\hline Desisto! & $\begin{array}{l}\text { Desenhar o contorno de um } \\
\text { rosto no ar (em um intervalo da } \\
\text { M.A.E. parei para "passar o } \\
\text { texto na cabeça" e esta ação foi } \\
\text { decantada). }\end{array}$ & $\begin{array}{l}\text { Quando eu fecho os olhos } \\
\text { você é bonito Valmont, ou } \\
\text { corcunda se eu desejar. (..) } \\
\text { O melhor seria ser cego e } \\
\text { surdo e mudo. A paixão das } \\
\text { rochas. }\end{array}$ & $\begin{array}{l}\text { Tocar no } \\
\text { contorno do } \\
\text { rosto, } \\
\text { acariciar } \\
\text { Valmont. }\end{array}$ \\
\hline Tô bêbada! & $\begin{array}{l}\text { Desço da mesa com gestos } \\
\text { pesados, caminho em torno do } \\
\text { praticável central. O olhar } \\
\text { direcionado a Valmont. }\end{array}$ & $\begin{array}{l}\text { Eu te assustei, Valmont? } \\
\text { Como você é fácil de } \\
\text { desanimar. Não o conhecia } \\
\text { assim. }\end{array}$ & $\begin{array}{l}\text { Interrogar } \\
\text { Valmont. }\end{array}$ \\
\hline Filho da puta! & (Idem.) & $\begin{array}{l}\text { As damas depois de mim lhe } \\
\text { deixaram mágoas? }\end{array}$ & $\begin{array}{l}\text { Agredir } \\
\text { Valmont. }\end{array}$ \\
\hline Bem feito! & (Idem.) & Lágrimas? & (Idem). \\
\hline $\begin{array}{l}\text { Ele está } \\
\text { apaixonado! }\end{array}$ & (Idem.) & $\begin{array}{l}\text { Você tem um coração } \\
\text { Valmont? Desde quando? }\end{array}$ & $\begin{array}{l}\text { Ironizar } \\
\text { Valmont. }\end{array}$ \\
\hline Não pode ser! & Páro. & $\begin{array}{l}\text { Ou será que a sua virilidade } \\
\text { estragou com as minhas } \\
\text { sucessoras. }\end{array}$ & Vacilar. \\
\hline Pera aí! & (Idem). & $\begin{array}{l}\text { Ou a sucessora de minha } \\
\text { sucessora te mandou } \\
\text { passear. }\end{array}$ & Arriscar. \\
\hline Pera aí! & Preparo a aproximação. & O amante abandonado. & Descobrir. \\
\hline \multirow[t]{2}{*}{ Pera aí! } & $\begin{array}{l}\text { Subo na mesa e o cumprimento } \\
\text { (mimesis de imagens de filmes). }\end{array}$ & $\begin{array}{l}\text { Não. Não retire sua tenra } \\
\text { oferta meu amando senhor. } \\
\text { Eu cumpro. }\end{array}$ & $\begin{array}{l}\text { Oferecer-se, } \\
\text { "ao seu } \\
\text { dispor". }\end{array}$ \\
\hline & Olho para a platéia. & $\begin{array}{l}\text { Eu cumpro de qualquer } \\
\text { modo. }\end{array}$ & $\begin{array}{l}\text { Revelar a } \\
\text { submissão. }\end{array}$ \\
\hline
\end{tabular}




\begin{tabular}{|c|c|c|c|}
\hline Que merda! & $\begin{array}{l}\text { Forma de "empurrar o ar" para a } \\
\text { diagonal esquerda baixa, } \\
\text { revesando as mãos, com } \\
\text { velocidade e tônus alterados; } \\
\text { bater no corpo. }\end{array}$ & $\begin{array}{l}\text { A paixão dos corpos. } O \\
\text { martírio de viver e não ser } \\
\text { Deus. Ter consciência e } \\
\text { nenhum poder sobre a } \\
\text { matéria. }\end{array}$ & $\begin{array}{l}\text { Dar chilique, } \\
\text { repudiar o } \\
\text { corpo, bater. }\end{array}$ \\
\hline Que merda! & Páro; penso. & $\begin{array}{l}\text { Não há sentimentos a temer. } \\
\text { Nunca te amei como posso } \\
\text { te odiar. Rocemos nossa } \\
\text { pele uma contra a outra. }\end{array}$ & (Idem). \\
\hline $\begin{array}{l}\text { Que merda, que } \\
\text { merda, que } \\
\text { merda! }\end{array}$ & $\begin{array}{l}\text { Retomo com frenesi: forma de } \\
\text { "empurrar o ar" para a diagonal } \\
\text { esquerda baixa, revesando as } \\
\text { mãos, com velocidade e tônus } \\
\text { alterados. }\end{array}$ & $\begin{array}{l}\text { Não se precipite Valmont, } \\
\text { assim está bem. }\end{array}$ & \\
\hline Que merda! & $\begin{array}{l}\text { Bater no ventre, os punhos } \\
\text { fechados, as mãos juntas. }\end{array}$ & Sim. & $\begin{array}{l}\text { Repudiar o } \\
\text { "ser mulher". }\end{array}$ \\
\hline Que merda! & (Idem). & Sim. & (Idem). \\
\hline Que merda! & (Idem). & Sim. & (Idem). \\
\hline Que merda! & (Idem). & Sim. & (Idem). \\
\hline Que merda... & Olhar para a platéia. & Isto foi bem encenado não? & $\begin{array}{l}\text { Revelar que } \\
\text { não é o } \\
\text { importante. }\end{array}$ \\
\hline $\begin{array}{l}\text { Só vou te amar } \\
\text { depois de morto! }\end{array}$ & $\begin{array}{l}\text { Os braços ao longo do corpo, } \\
\text { rígidos, o queixo inclinado } \\
\text { (imagem resultante do jogo com } \\
\text { a Volange). }\end{array}$ & $\begin{array}{l}\text { A paixão do meu corpo não } \\
\text { me interessa. Não sou } \\
\text { nenhuma criada de estábulo. } \\
\text { Estou completamente fria } \\
\text { Valmont. Minha vida, minha } \\
\text { morte, meu amado. }\end{array}$ & $\begin{array}{l}\text { Revela que } \\
\text { irá até o fim: } \\
\text { a morte. }\end{array}$ \\
\hline
\end{tabular}

(Segunda Modalidade de Jogo: a estrutura de regras provocou a reinscrição das ações físicas). 


\subsubsection{O Esquema de Revesamentos}

O esquema de revesamentos implicou uma organização rítmica, pautada pelas sucessivas substituições, que inscreveram os sucessivos impulsos para começar ação física e fala. Foi possível manejar o tempo de desenvolvimento da ação. Com o envolvimento com a subpartitura foi possível "saborear" o desenrolar da ação física que "durou" até o texto se instalar de supetão e arrematar um sentido, pontuando o movimento. Foi o que aconteceu com IDJIOTA (subpartitura que sustentou o desenvolvimento da ação física) e VAAAAUUMOOOUM (que finalizou a ação). O tônus, neste caso, aumentou bastante antes da fala se inscrever. Houve uma suspensão do sentido (enquanto a ação física se desenvolvia) e o arremate com a inscrição da fala. A inscrição do segundo significante possibilitou que, da relação entre os dois, uma ação fosse evocada. Outras vezes, a ação física e a fala se desenvolveram juntas. Em trechos longos foi preciso manejar o foco e provocar sucessivos revesamentos (para renovar o impulso da fala): "(DEIXEUSONHAR ) Um minuto (DEIXEUSONHAR), isto sim é a eternidade (DEIXEUSONHARR) em que me senti feliz (DEIXEUSONHAR) graças a sua companhia (DEIXEUSONHARRR)".

\begin{tabular}{|l|l|l|l|l|}
\hline SUBPARTITURA & \multicolumn{1}{|c|}{ AÇÕES FÍSICAS } & \multicolumn{1}{|c|}{ IMAGENS } & \multicolumn{1}{|c|}{ VOZ } \\
\hline "Palavras & Inscritas em função & São evocadas. Por & Emendado na & A imagem \\
inventadas" são & da subpartitura e & articulação & subpartitura é & vocal é inscrita \\
elementos & das regras "fazer & espontânea se & descarregado e & na posição do \\
concretos para o & gestos grandes" e & integram na ação & pontua o & espontâneo e \\
envolvimento & "ocupar todo o & física. & movimento. & integrada. \\
com o foco. & espaço" & & \\
\hline
\end{tabular}




\section{Considerações Finais}

É preciso considerá-la não como substância (pessoa, alma, caráter, indivíduo único), mas como lugar, lugar geométrico de estruturas diversas.

É preciso, por certo, tomá-la como o ponto de convergência de funcionamentos relativamente independentes.

Ubersfeld

O que caracteriza o pensamento criativo é justamente o seu fluir por saltos através de uma desorientação repentina que o obriga a reorganizar-se de uma nova maneira abandonando a casa bem ordenada. É o pensamento-emvida, não retilíneo, não homogêneo.

Barba

A vida é isso - um rodeio, um rodeio obstinado, em si mesmo, transitório e caduco, e desprovido de significação. Por que é que, neste ponto de suas manisfestações que se chama homem, algo se produz, que insiste através desta vida, e que se chama sentido? (...) Um sentido é uma ordem que surge.

Lacan

Assim que a linguagem existe, ela é universo.

Lacan

Detalhar significa, portanto, descobrir diferenças. Armando Sérgio da Silva 
Os revesamentos estabelecem relação rítmica, pulsional com a enunciação, e apontam para a perspectiva de uma relação de substituição, de troca, entre o elemento interno e o externo. Esta pode ser considerada uma modalidade específica de subpartitura. Segundo Barba, apesar de implicar o mesmo princípio (a sustentação interna), subpartituras fazem juz a estéticas diversas. Borrar as formas das partituras e ir ao encontro da ação não significa abrir mão deste "outro sentido da cena" que é o engajamento na construção da linguagem teatral, no jogo de combinação de significantes próprios desta linguagem, de resoluções cênicas híbridas, originais. Gostaria de concluir com isto: há um campo de experimentação da subpartitura.

Em certo momento, o trilho subpartiturizado de imagens acústicas nos conduziu por uma ação silenciosa ("Merteuil caminha com uma carta nas mãos, se situa de costas para a platéia, deposita-a sobre a mesa e vira o rosto de repente, como se tivesse ouvido um barulho"). Pela primeira vez em minha trajetória como atriz consegui, efetivamente, "saborear o tempo". Levar `as últimas conseqüências o detalhamento das "palavras inventadas" para uma subpartitura implicaria a construção de que registro do corpo? Está aberta a porta para uma problematização da inscrição do registro do corpo como jogo.

Em Knébel, por exemplo, o "detalhamento" implica que o ator escreva tudo o que vê, toca, cheira, ouve e, também, sucessivas trocas de um registro para o outro: o ator treina passar do olfato para a visão, para o tato, para a escuta $\left({ }^{*}\right)$. Treina, também, pensar em um assunto e falar sobre outro. Inscreve a idéia de "desatenção" e um automatismo próprio das 
atividades cotidianas, bem como o interesse por este "outro pensamento", que se torna evidente (e poderíamos dizer que "desperta a curiosidade, traz questões, propõe jogo"). Knébel aponta para um mecanismo de transferência da atenção (a alternância do foco) entre duas elaborações verbais.

De certa forma, o princípio da subpartitura que inscrevemos com Quarteto é o mesmo. No entanto, a inscrição de um corpo "cotidiano" conta com "outras regras": gestos pequenos, pouca atividade externa, abstração do ambiente. $\mathrm{O}$ ator treina (repete, exercita) a inscrição de um corpo que é este nosso que cotidianamente carregamos: uma inscrição onde elementos se combinam de maneira que a modificação de um deles altera a resultante.

Com Quarteto, colocamos em jogo fazer gestos grandes e ocupar todo o espaço. Instantaneamente o repertório constituído em processo (com partituras físicas transformadas) foi presentificado para auxiliar a resolução do problema. Neste sentido, a resolução cênica implicou certa mescla, certo hibridismo no que diz respeito a um significante importante na linguagem teatral: a construção do chamado "corpo extra-cotidiano". O teatro constrói significantes que Ihe são próprios: "contra-ação", "efeito de estranhamento", "teatralização", "corpo extra-cotidiano", etc. Segundo Barba, estas idéias são suporte, são subpartitura. Treinamos partituras físicas que escapavam ao registro cotidiano. Trabalhamos com certa estilização do corpo. Ao mesmo tempo, o princípio da divisão do foco inscreveu, em cena, "pensamento", e o interesse de alguém por algo: de Merteuil (mulher) por Valmont (homem). Estava implicada a idéia de humano, de pessoa, na nossa subpartitura.

O "detalhe" se define para Jakobson como instância de um processo metonímico e, como metonímia, é propriamente o que articula 
"contexto". Ele cita o exemplo do suicídio de Anna Karenina (Tólstói se concentra na bolsa da heroína) e Guerra e Paz (as descrições do lábio superior e os ombros nús) $\left.{ }^{*}\right)$. O uso da metonímia em detrimento da metáfora implica, para Jakbson, um cinema e uma literatura de tendência realista.

No que diz respeito ao trabalho do ator e a inscrição do seu corpo em cena, o "detalhe" pode ser problematizado. Ao realizar pesquisa com texto de Maeterlinck, Stanislavski inscreve o registro cotidiano sem implicar o Realismo (*). Isto nos faz pensar que instâncias específicas da encenação implicam, para o ator, o manejo de elementos específicos na subpartitura. A inscrição de comportamentos cotidianos, por exemplo, pode não estar veiculada `a estética realista, assim como é possível um corpo híbrido. Isto nos faz pensar que a exigência de uma inscrição da personagem, da idéia de realidade, da idéia de cotidiano, espontaneidade, crítica, etc, implicam elementos distintos para um jogo de composição da subpartitura. $\mathrm{O}$ que quero dizer é que percebo um campo de pesquisa com a subpartitura que depende da composição, da combinação e oposição de elementos. Gostaria de finalizar com isto: a perspectiva da inscrição cênica de um corpo a partir

(*) JAKOBSON, Roman. Lingüística e Comunicação. São Paulo: Cultrix, 19-?, pg. 57.

$\left({ }^{* *}\right)$ O termo realismo assumiu na filosofia sentidos bastante diversos (ver ABBAGNANO, Nicola. Dicionário de Filosofia, São Paulo: Martins Fontes, 2007). Na literatura, designa o movimento que surge, no século XIX, em reação ao Romantismo (com a publicação de Madame Bovary, de Gustave Flaubert em 1957). A proposta era retratar a "realidade", as "pessoas" (substituindo, então, a subjetividade romântica por uma visão fiel e objetiva do mundo). No teatro o termo assume particularidades. Segundo Pavis, "o realismo nem sempre se distingue com clareza da ilusão ou do naturalismo. Esses rótulos têm em comum a vontade de duplicar a realidade através da cena, imitá-la da maneira mais fiel possível. O meio cênico é reconstituído de modo a enganar sobre sua realidade. Os diálogos se inspiram nos discursos de determinada época ou classe socioprofissional. $O$ jogo do ator torna o texto natural ao máximo, reduzindo os efeitos literários e retóricos pela ênfase na espontaneidade e na psicologia. Assim, paradoxalmente, para fazer verdadeiro o real, é necessário saber manipular o artifício: 'Fazer verdadeiro consiste, portanto, em dar a ilusão completa do verdadeiro (...). Daí concluo que os realistas de talento deveriam se chamar, mais propriamente, ilusionistas' (MAUPASSANT)" (PAVIS, idem: 325-226). 
da elaboração de uma certa composição e detalhamento da subpartitura.

Nossa investigação com Quarteto contou com um revesamento fixo entre dois pares de elementos (duas regras e duas elaborações verbais), além de um reservatório de imagens em torno da ficção, da cultura teatral e do próprio corpo. Gostaria de terminar com isto: apontando para a importância desta instância que não é a partiturização cênica da obra, o seu elemento externo, mas o conjunto de elementos internos que entram no jogo do ator (passíveis de combinação, revesamento, oposição, detalhamento). Há um campo de pesquisa sobre ela e suas implicações sobre a inscrição do corpo, bem como da palavra em cena. 


\section{Referências Bibliográficas}

ABBAGMANO, Nicola. Dicionário de Filosofia. São Paulo: Martins Fontes, 2007.

ABIRACHED, Robert. L'Acteur et Son Jeu. In COUTY, Daniel \& REY, Alan (org.) Le tréâtre. Paris: Brodas, 1980. Tradução não publicada de José Ronaldo FALEIRO.

Paris: Gallimard, 1994.

APPIA, A. A Obra de Arte Viva, notas e trad. Redondo Júnior, Lisboa, Arcádia, S/d.

ARISTÓTELES. Poética. Trad. Eudoro de Souza. Lisboa: Guimarães, s. d. Coleção Textos Universitários.

ARTAUD, Antoin. O Teatro e Seu Duplo. São Paulo: Hucitec, 1994.

ASLAN, Odette. O Ator no Século XX. São Paulo: Perspectiva, 1994.

BARBA, Eugenio. Além das Ilhas Flutuantes. São Paulo: Hucitec, 1991.

A Canoa de Papel: Tratado de Antropologia Teatral. São

Paulo: Hucitec, 1994.

. La Canoa di Carta: Trattato di Antropologia Teatrale. Bologna:

II Mulino, 1993.

.Terra de Cinzas e Diamantes: Minha Aprendizagem na

Polônia: Aeguida de 26 Cartas de Jergy Grotowski a Eugenio Barba. São Paulo: Perspectiva, 2007.

BARBA, Eugenio \& SAVARESE, Nicola. A Arte Secreta do Ator. São Paulo: Hucitec, 1995BARTHES, Roland. Novos Ensaios Críticos. São Paulo, Cultrix, 1974.

. O Grau Zero da Escritura. São Paulo, Cultrix, 1971.

BONFITTO, Matteu. O Ator-compositor: As Ações como Eixo: de Stanislavski 'a Barba. São Paulo, Perspectiva, 2007.

BRECHT, Bertold. Estudos Sobre Teatro. Lisboa: Portugalia, 19-?

BROOK, Peter. A Porta Aberta: Reflexões Sobre a Interpretação e o Teatro. Trad.: Antonio Mercado - $2^{a}$ ed. - Rio de Janeiro: Civilização Brasileira, 2000.

BORNHEIM, Gerd. O Sentido e a Máscara. São Paulo: Perspectiva, 1969.

CÂNDIDO, Antônio. A Personagem de Ficção. São Paulo: Perspectiva, 1992.

CARLSON, Marvin. Teorias do Teatro. São Paulo: Unesp,1997.

CHEKHOV, Michael. Para o Ator. São Paulo: Martins Fontes, 2003.

CHNAIDERMAN, Miriam. O Hiato Convexo: Literatura e Psicanálise. São Paulo: Brasiliense, 1989.

COELHO, Teixeira. O que é Ação Cultural. São Paulo: Brasiliense, 2006. Em Cena, o Sentido. São Paulo: Duas Cidades, 1980.

COHEN, Renato. Performance como Linguagem. São Paulo: Perspectiva, 2002

COURTNEY, Richard. Jogo, Teatro e Pensamento. São Paulo: Perspectiva, 2003.

CRAIG, Gordon. Da Arte do Teatro. Lisboa: Arcádia, s/d.

DORT, Bernard. O Teatro e sua Realidade. Trad. Fernando Peixoto. São Paulo: Perspectiva, 1977.

DOSSE, François. História do Estruturalismo. Volume I. Bauru, SP: Edusc, 2007.

ECO, Umberto. A Estrutura Ausente. São Paulo, Perspectiva, 1976. 
Lector in Fábula. São Paulo, Perspectiva, 2002.

FÉRAL, Josette. Os Camiños do Actor. Editorial Galaxia, 2004.

Teatro, Teoria y Práctica, Más Allá de las Fronteiras. Buenos Aires: Galerna, 2004.

FERRACINI, Renato. A Arte de não Interpretar como Poesia Corpórea do Ator. Campinhas: Unicamp, 2003.

FREUD, Sigmund. Escritos Sobre a Psicologia do Inconsciente. Volume I. Rio de Janeiro: Imago, 2004.

FOUCAULT, Michel. O Que é um Autor, Lisboa: Vega, 2000.

GROTOWSKI, Jerzy. Em Busca de um Teatro Pobre. Rio de Janeiro: Civilização Brasileira, 1987.

Teatro Laboratório. México: Siglo XXI, 1980.

GUINSBURG, Jacó. Stanislavski, Meyerhold \& Cia. São Paulo: Perspectiva, 2001.

Perspectiva, 1985.

Stanislavski e o Teatro de Arte de Moscou. São Paulo:

HOLANDA, Buarque. Novo Dicionário da Língua Portuguesa. Rio de Janeiro: Nova Fronteira, 1986.

JAKOBSON, Roman. Lingüística. Poética. Cinema. São Paulo: Perspectiva, 2004.

Lingüística e Comunicação. São Paulo: Cultrix, 19-?

JANUZELLI, Antonio. A Apredizagem do Ator. São Paulo: Ática, 1986.

JIMENEZ, Sergio. El Evangelio de Stanislavski Segun sus Apostoles. México: Gaceta, 1990.

KNÉBEL, María. La Poética de la Pedagogía Teatral. México: Siglo XXI, 2002. . El Último Stanislavski. Madrid, Ed. Fundamentos: 2005.

KOUDELA, Ingrid. Jogos Teatrais. São Paulo: Perspectiva, 1991.

Brecht, Um Jogo de Aprendizagem. São Paulo: Perspectiva,

1991.

Texto e Jogo. São Paulo: Perspectiva, 1996.

Brecht na Pós-modernidade. São Paulo: Perspectiva, 1991.

Um Vôo Brechtiano. São Paulo: Perspectiva, 1991.

KUSNET, Eugenio. Ator e Método. São Paulo: Hucitec, 1992.

KRISTEVA, Julia. História da Linguagem. Lisboa: Edições 70, 2007.

LACAN, Jacques. Escritos. São Paulo: Perspectiva, 1992.

. O Seminário. Livro 1: Os Escritos Técnicos de Freud. Rio de Janeiro: Jorge Zahar, 19-?

o Seminário. Livro 2: O Eu na Teoria de Freud e na Técnica da Psicanálise. Rio de Janeiro: Jorge Zahar, 1983.

.O Seminário. Livro 3: As Psicoses. Rio de Janeiro: Jorge Zahar, 2008.

Jorge Zahar, 1995.

O Seminário. Livro 4: A Relação de Objeto. Rio de Janeiro:

. O Seminário. Livro 11: Os Quatro Conceitos Fundamentais da Psicanálise. Rio de Janeiro, Jorge Zahar, 1983.

LACLOS, Choderlos. As Ligações Perigosas. Porto Alegre: L\&PM, 2008.

LAPLANCHE e PONTALIS. Vocabulário da Psicanálise. São Paulo: Martins Fontes, 2004.

LÉVI-STRAUSS, Claude. As Estruturas Elementares do Parentesco. Petrópolis: Vozes, 2008. 
LOTMAN, luri. A Estrutura do Texto Artístico. Lisboa: Estampa, 1978.

LUDWIK, Flaszen. O Teatro Laboratório de Jerzy Grotowski. São Paulo: Perspectiva, 2007.

MEICHES, Mauro e FERNANDES, Silvia. Sobre o Trabalho do Ator. São Paulo: Perspectiva.

MÜLLER, Heiner. Quatro Textos para Teatro: Mauser, Hamlet-máquina, A Missão, Quarteto. São Paulo: Hucitec, 1987. . Gerra sem Batalha: Uma Vida entre Duas Ditaduras. São Paulo: Estação Liberdade, 1997. O Espanto no Teatro. São Paulo: Perspectiva, 2003.

Terra, 1983. Medeamaterial e Outros Textos. Rio de Janeiro: Paz e

PAVIS, Patrice. Dicionário de Teatro. São Paulo, Perspectiva, 1999.

- O Teatro no Cruzamento de Culturas. São Paulo: Perspectiva, 2008.

. A Análise dos Espetáculos. São Paulo: Perspectiva, 2003.

PUPO, Maria Lúcia. Entre o Mediterrâneo e o Atlântico: Uma Aventura Teatral. São Paulo: Perspectiva, 2005.

QUINET, Antonio. A Lição de Charcot. Riode Janeiro: Jorge Zahar, 2005.

RICHARDS, Thomas. Al Lavoro com Grotowski sulle Azioni Fisiche. Milano, Ubulibri, 1993.

RÖHL, Ruth. O Teatro de Heiner Müller: Modernidade e Pós-Modernidade. São Paulo: Perspectiva, 1997.

ROUBINE, Jean-Jacques. A Linguagem da Encenação Teatral. Rio de Janeiro, Jorge Zaar, 1998.

2002.

A Arte do Ator. Rio de Janeiro: Jorge Zahar,

RYNGAERT, Jean-Pierre. Introdução ’a Análise do Teatro. São Paulo: Martins Fontes, 1991

. Ler o Teatro Contemporâneo. São Paulo: Martins

Fontes, 1998.

2009.

Sud, 2005.

RYNGAERT, Jean-Pierre \& SERMON, Julie. Le Personnage Théâtral Contemporain: Décomposition, Recomposition. Montreuil-sous-Bois: Éditions Théatrales, 2006.

SARRAZAC, Jean-Pierre. O Futuro do Drama. Porto: Campo das Letras, 2002.

SAUSURRE, Ferdinand. Curso de Lingüística Geral. São Paulo: Cultrix, 2006.

SPOLIN, Viola. Improvisação para o Teatro. São Paulo: Perspectiva, 1992.

1999. . O Jogo Teatral no Livro do Diretor. São Paulo: Perspectiva, Jogos Teatrais na Sala de Aula: o Livro do Professor. São Paulo: Perspectiva, 2007. . Jogos Teatrais: O Fichário de Viola Spolin. São Paulo: Perspectiva, 2000.

SILVA, Armando Sérgio. Oficina: do Teatro ao Te-ato. São Paulo: Perspectiva, 1981 
STANISLAVSKI, Constantin. A Criação de Um Papel. Rio de Janeiro: Civilização Brasileira, 2005.

Civilização Brasileira, 1970.

A Construção da Personagem. Rio de Janeiro: A Preparação do Ator. Rio de Janeiro: Civilização

Brasileira, 1968.

Brasileira, 1972. . A Preparação de Um Papel. Rio de Janeiro: Civilização

Brasileira, 1989.

STRASBERG, Lee. O Sonho de uma Paixão. Rio de Janeiro: Civilização Brasileira, 1990. Acting. New York: Crow, 1965.

SZONDI, Peter. Teoria do Drama Moderno. São Paulo: Cosac \& Naify, 2001.

TAKEDA, C. Layher. O Cotidiano de uma Lenda: Cartas do Teatro de Arte de Moscou. São Paulo: Perspectiva, 2003.

TODOROV, Tristan. As Estruturas Narrativas. São Paulo: Perspectiva, 2003.

UBERSFELD, Anne. Para Ler o Teatro. São Paulo: Perspectiva, 2005.

VANIER, Alain. Lacan. São Paulo: Estação Liberdade, 2005.

VASSÍLIEV, Anatoli. Sept ou Huit Leçons de Théâtre. Paris: P.O.L., 1999.

ZUMTHOR, Paul. Performance, Recepção, Leitura. São Paulo: Cosac \& Naify, 2007.

\section{Artigos publicados em Jornais e Revistas}

BETTS, Jaime. Ato analítico, Ato religioso e Ato de Criação Artística. Revista da Associação Psicanalítica de Porto Alegre, n. 149, agosto de 2006.

PUPO, Maria Lúcia de S.B. O Lúdico e a Construção do Sentido. Sala Preta. Departamento de Artes Cênicas, ECA-USP, junho de 2001, pp. 181187.

SARRAZAC, Jean-Pierre. L'impersonnage. Études théâtrales 20. "Jouer le monde". Paris/Louvain, Centre d' études théâtrales/Institut d' etudes théâtrales, 2001

A Oficina de Escrita Dramática. Educação e Realidade. Arte, Criação e Aprendizagem. Universidade Federal do Rio Grande do Sul, v.30, n. 2, jul./dez. 2005, pp. 203 -215.

\section{Dissertações e Teses}

ALMEIDA, Marcio Aurelio Pires de. O Encenador como Dramaturgo: A Escrita Poética do Espetáculo. Tese de Doutoramento, Universidade de São Paulo - Escola de Comunicações e Artes, São Paulo-SP, 1995.

CHNAIDERMAN, Miriam Schenkman. Corpo do Discurso e o Discurso do Corpo: Stanislavski e Freud. Tese de Doutoramento, Universidade de São Paulo - Escola de Comunicações e Artes, São Paulo-SP, 1994. 
CONSENTINO, Mariane Tezza. As Três Irmãs e a Subjetividade no Trabalho do Ator: Contribuições da Técnica de Clown. Dissertação de Mestrado Escola de Comunicações e Artes, São Paulo-SP, 2008.

DORNELLAS, José Raimundo. Caminhos da Formação do Ator: Conexões Interdiciplinares de Quatro Experiências. Dissertação de Mestrado Escola de Comunicações e Artes, São Paulo-SP, 2008.

JANUZELLI, Antonio Luiz Dias. O Ofício do Ator e o Estágio das Transparências. Tese de Doutoramento, Universidade de São Paulo Escola de Comunicações e Artes, São Paulo-SP, 1992.

LOPES, Elisabeth Silva. Ainda é Tempo de Bufões. Tese de Doutoramento. Universidade de São Paulo - Escola de Comunicações e Artes, São Paulo-SP, 2001.

. A Linguagem Experimental do Teatro Brasileiro: Anos 80. Dissertação de Mestrado. Universidade de São Paulo - Escola de Comunicações e Artes, São Paulo-SP, 1992.

PUPO, Maria Lúcia de S. B. Palavras em Jogo. Textos Literários e TeatroEducação. Tese de Livre-Docência apresentada à ECA/USP, 1997.

SILVA, Armando Sérgio da. Interpretação: Uma Oficina da Essência. Tese de Livre Docência, Universidade de São Paulo - Escola de Comunicação e Artes, São Paulo-SP, 1999.

A EAD do Dr. Alfredo: Uma Oficina de Atores. Tese de Doutoramento. Universidade de São Paulo - Escola de Comunicações e Artes, São Paulo-SP, 1987. 